\title{
Facility Effluent Monitoring Plan for the Tank Farm Facility
}

D. D. Bachand

G. M. Crummel

Date Published

May 1995

Prepared for the U.S. Department of Energy Office of Environmental Restoration and Waste Management

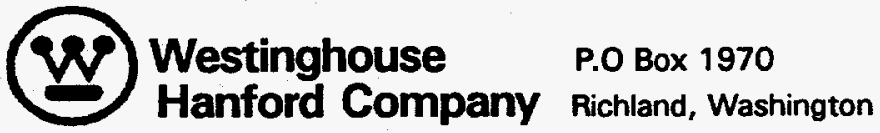

Hanford Operations and Engineering Contrector for the

U.S. Department of Energy under Contract DE-ACO6-87RL10930

Approved for Public Release 


\section{RELEASE AUTHORIZATION}

Document Number: $\quad$ WHC-EP-0479-1

Document Title: $\quad$ Facility Effluent Monitoring Plan for the Tank Farm Facility

Release Date: $\quad 6 / 7 / 95$

This document was reviewed following the procedures described in WHC-CM-3-4 and is:

APPROVED FOR PUBLIC RELEASE

WHC Information Release Administration Specialist:

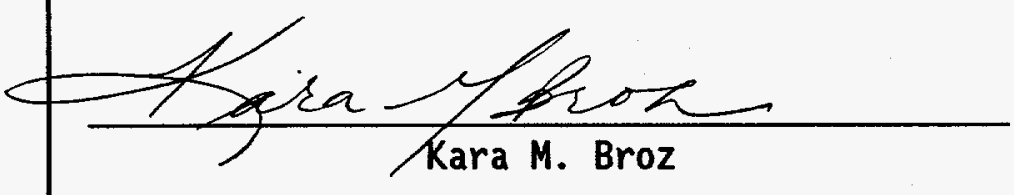




\section{DISCLAIMER}

This report was prepared as an account of work sponsored by an agency of the United States Government. Neither the United States Government nor any agency thereof, nor any of their employees, make any warranty, express or implied, or assumes any legal liability or responsibility for the accuracy, completeness, or usefulness of any information, apparatus, product, or process disclosed, or represents that its use would not infringe privately owned rights. Reference herein to any specific commercial product, process, or service by trade name, trademark, manufacturer, or otherwise does not necessarily constitute or imply its endorsement, recommendation, or favoring by the United States Government or any agency thereof. The views and opinions of authors expressed herein do not necessarily state or reflect those of the United States Government or any agency thereof. 


\section{DISCLAIMER}

Portions of this document may be illegible in electronic image products. Images are produced from the best available original document. 


\section{APPROVAL}

Document Title: Facility Effluent Monitoring Plan for the Tank Farm Facility

Prepared by:

D. D. Bachand

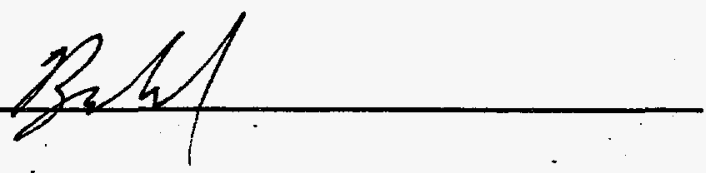
Advanced Engineer

Prepared by:

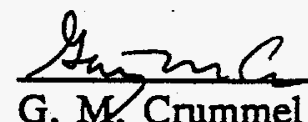

$\frac{4 / 12 / 95}{\text { Date }}$

Senior Engineer

Approved by:

$$
\text { R.D. Gustawe }
$$

R. D. Gustavson, Manager

Tank Farm Eg vironmental Engineering

$\frac{4 / 12 / 95}{\text { Date }}$

$\frac{4 / 12 / 95}{\text { Date }}$

Approved by:<smiles>C=CC1CCCCC1CCC</smiles>

J. H. Wicks, Jr., Manager

East Tank Farm Operations

Approved by:<smiles>[Mg]=[W]</smiles><smiles>C1CC2CCC1C2</smiles>

D. P. keber, Mapager

Wes Tank Farm Operations

Approved by:<smiles>CC1(C)CCCC1</smiles>

J. L. (tee, Director

TWRS Plant

Approved by:

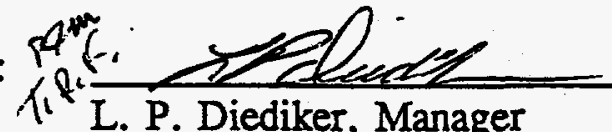

L. P. Diediker, Manager

Effluent Monitoring

Approved by: $\frac{14 a y 95}{\text { Date }}$

$\frac{4-24-45}{\text { Date }}$

$\frac{6 / 7 / 95}{\text { Date }}$

$\frac{5=3-45}{\text { Date }}$

$6 / 5 / 95$

Date
L.W. Vance

L. W. Vance, Principal Quality Assurance Engineer Analytical and Environmental Quality Assurance 


\title{
FACILITY EFFLUENT MONITORING PLAN FOR THE TANK FARMS FACILITIES
}

\author{
D. D. Bachand \\ G. M. Crummel
}

\begin{abstract}
A facility effluent monitoring plan is required by the U.S. Department of Energy in DOE Order 5400.1* for any operations that involve hazardous materials and radioactive substances that could impact employee or public safety or the environment. This document is prepared using the specific guidelines identified in A Guide for Preparing Hanford Site Facility Effluent Monitoring Plans, WHC-EP-0438**. This facility effluent monitoring plan assesses effluent monitoring systems and evaluates whether they are adequate to ensure the public health and safety as specified in applicable federal, state, and local requirements.
\end{abstract}

This facility effluent monitoring plan shall ensure long-range integrity of the effluent monitoring systems by requiring an update whenever a new process or operation introduces new hazardous materials or significant radioactive materials. This document must be reviewed annually even if there are no operational changes, and it must be updated as a minimum every three years.

\footnotetext{
*General Environmental Protection Program, DOE Order 5400.1, U.S. Department of Energy, Washington, D.C., 1988.

**A Guide for Preparing Hanford Site Facility Effluent Monitoring Plans, WHC-EP-0438-1, Westinghouse Hanford Company, Richland, Washington, 1992.
} 
WHC-EP-0479-1

This page intentionally left blank. 


\section{CONTENTS}

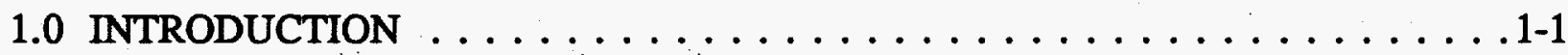

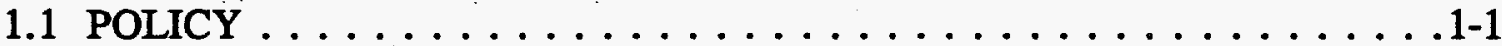

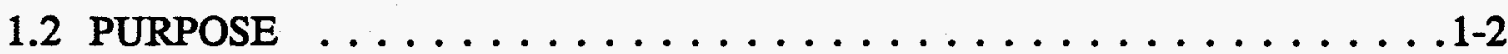

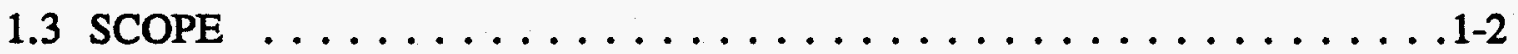

2.0 FACILITY DESCRIPTION $\ldots \ldots \ldots \ldots \ldots \ldots \ldots \ldots \ldots \ldots \ldots \ldots \ldots . \ldots \ldots$

2.1 FACILITY PHYSICAL DESCRIPTION $\ldots \ldots \ldots \ldots \ldots \ldots \ldots \ldots .2-2$

2.1.1 Tank Farms as Part of the 200 Area Facilities . . . . . . . . 2-2

2.1.2 Double-Shell Waste Tanks . . . . . . . . . . . 2-2

2.2 PROCESS DESCRIPTION $\ldots \ldots \ldots \ldots \ldots \ldots \ldots \ldots \ldots$

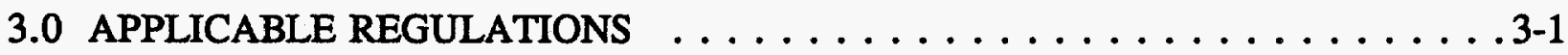

3.1 U.S. DEPARTMENT OF ENERGY ORDERS $\ldots \ldots \ldots \ldots \ldots \ldots \ldots$. . . .

3.1.1 U.S. Department of Energy Order $5400.1 \ldots \ldots \ldots$. . . . 3-1

3.1.2 U.S. Department of Energy Order $5400.5 \ldots \ldots \ldots \ldots$. . . . . . . .

3.2 FEDERAL REGULATIONS $\ldots \ldots \ldots \ldots \ldots \ldots \ldots \ldots \ldots . \ldots \ldots$

3.2.1 Environmental Protection Agency Regulations on National Emission Standards for Hazardous Air Pollutants

40 Code of Federal Regulations $61 \ldots \ldots$. . . . . . . 3-5

3.2.2 Reportable Quantities 40 Code of Federal Regulations 302 . . . . 3-6

3.3 STATE REGULATIONS $\ldots \ldots \ldots \ldots \ldots \ldots \ldots \ldots \ldots \ldots$. . . . . . . . . .

3.3.1 Washington State Ambient Air Quality Standard and

Emission Limits for Radionuclides WAC-173-480 . . . . . . . 3-6

3.3.2 Groundwater Protection . . . . . . . . . . . . . 3-6

3.3.3 Dangerous Waste Regulations . . . . . . . . . . . . 3-7

3.4 LOCAL REGULATIONS $\ldots \ldots \ldots \ldots \ldots \ldots \ldots \ldots \ldots . . \ldots \ldots$

3.4.1 Benton, Franklin, and Walla Walla Counties

Air Pollution Control Authority . . . . . . . . . . 3-7

3.5 AIR EMISSIONS $\ldots \ldots \ldots \ldots \ldots \ldots \ldots \ldots \ldots \ldots \ldots \ldots \ldots$

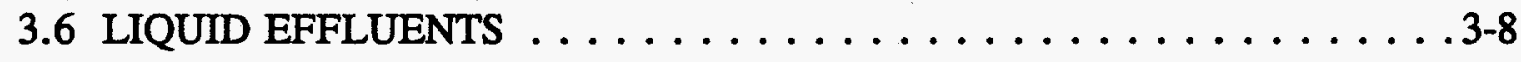

4.0 IDENTIFICATION AND CHARACTERIZATION OF

EFFLUENT STREAMS $\ldots \ldots \ldots \ldots \ldots \ldots \ldots \ldots \ldots \ldots .1$

4.1 IDENTIFICATION AND CHARACTERIZATION

OF SOURCE TERMS CONTRIBUTING TO

EACH EFFLUENT STREAM $\ldots \ldots \ldots \ldots \ldots \ldots \ldots \ldots \ldots$. . . . . . .

4.1.1 Emissions from Routine Operations . . . . . . . . . 4-1

4.1.2 Radionuclide Emissions of Concern . . . . . . . . . 4-2

4.2 HYPOTHESIZED UPSET CONDITION $\ldots \ldots \ldots \ldots \ldots \ldots \ldots \ldots$ 


\section{CONTENTS (Continued)}

5.0 EFFLUENT POINT OF DISCHARGE DESCRIPTION $\ldots \ldots \ldots \ldots \ldots \ldots$ 5-1

5.1 AIR EFFLUENTS $\ldots \ldots \ldots \ldots \ldots \ldots \ldots \ldots \ldots . \ldots \ldots$. 1

5.1.1 Stack 296-A-17; 241-AY and 241-AZ Tank Farm Exhaust . . . . 5-1

5.1.2 Stack 296-P-26; 241-AY and -AZ Backup Tank Farm Exhaust . . 5-2

5.1.3 Stack 296-A-25; 244-A Lift Station Catch Tank Exhaust . . . . . 5-2

5.1.4 Stack 296-A-27; 241-AW Tank Farm Exhaust . . . . . . . . . . 5-3

5.1.5 Stack 296-A-29; 241-AN Tank Farm Exhaust . . . . . . . . . . 5-4

5.1.6 Stack 296-A-40; 241-AP Tank Farm Exhaust . . . . . . . . . . 5-4

5.1.7 Stack 296-B-28; 244-BX Salt Well Receiver Exhaust . . . . . 5 5-5

5.1.8 Stack 295-C-5; CR Vault Cell and Vessel

Ventilation Exhaust . . . . . . . . . . . . . . . 5-6

5.1.9 Stack 296-P-16; 241-C-105 and 241-C-106 Tank Exhaust . . . . . 5-6

5.1.10 Stack 296-P-23; 241-SY Tank Farm Exhaust . . . . . . . . . . 5-7

5.1.11 Stack 296-P-28; 241-SY Backup Tank Farm Exhaust . . . . . . 5-7

5.1.12 Stack 296-S-15; 241-SX Tank Farm Exhaust . . . . . . . . . . . 5-9

5.1.13 Stack 296-S-22; 244-S Salt Well Receiver Tank and Annulus Exhaust . . . . . . . . . . . . . . . . . 5-10

5.1.14 Stack 296-T-18; 244-TX Salt Well Receiver Tank and Annulus Exhaust . . . . . . . . . . . . . . . 5-10

5.1.15 Stack 296-U-11; 244-U Salt Well Receiver Tank and Annulus Exhaust $\ldots \ldots \ldots \ldots \ldots \ldots \ldots \ldots$ 5-11

5.2 LIQUID EFFLUENTS $\ldots \ldots \ldots \ldots \ldots \ldots \ldots \ldots \ldots \ldots$. . . . . . . .

\subsection{EFFLUENT MONITORING/SAMPLING SYSTEM}

DESIGN CRITERIA . . . . . . . . . . . . . . . . . . . . 6-1

6.1 EFFLUENT MONITORING SYSTEM GENERAL DESIGN CRITERIA . . 6-1

6.2 EFFLUENT MONITORING SYSTEM

REQUIREMENTS/CONSIDERATIONS . . . . . . . . . 6-1

6.2.1 Measurement of Effluent Flow Rate . . . . . . . . . . 6-2

6.2.2 Measurement of Radionuclides . . . . . . . . . . . 6-2

6.2.3 Sampling or Monitoring Site Location (EPA Method 1) . . . . . 6-3

6.2.4 Sample Extraction (ANSI N13.1 1969) . . . . . . . . . 6-3

6.2.5 Sample Analysis (EPA Method 114) . . . . . . . . . . 6-6

6.2.6 Quality Assurance Program for Effluent Monitoring . . . . . . 6-6

6.3 ACCEPTANCE TEST PROCEDURE . . . . . . . . . . 6-7

6.4 CONTINUOUS AIR MONITOR $\ldots \ldots \ldots \ldots \ldots \ldots \ldots \ldots \ldots$. . . . . . $\ldots$.

\subsection{CHARACTERIZATION OF CURRENT EFFLUENT}

MONITORING SYSTEM $\ldots \ldots \ldots \ldots \ldots \ldots \ldots \ldots \ldots \ldots$. . . . . . . .

7.1 GENERIC STACK SAMPLING/MONITORING INSTRUMENTATION . . 7-1

7.1.1 Stack Sampling Probe $\ldots \ldots \ldots \ldots \ldots \ldots \ldots .7-2$

7.1.2 Record Sample Collection Filter Paper and Holder . . . . . . . 7-2 


\section{CONTENTS (Continued)}

7.1 .3 Rotameter $\ldots \ldots \ldots \ldots \ldots \ldots \ldots \ldots \ldots \ldots \ldots . \ldots \ldots$

7.1 .4 Gasmeter . . . . . . . . . . . . . . . . 7-3

7.1 .5 Vacuum Gauge $\ldots \ldots \ldots \ldots \ldots \ldots \ldots \ldots \ldots . \ldots \ldots$

7.1 .6 Flow Switch $\ldots \ldots \ldots \ldots \ldots \ldots \ldots \ldots \ldots .4 \ldots \ldots \ldots$

7.1 .7 Flow Regulator . . . . . . . . . . . . . . .7-4

7.1 .8 Vacuum Pump and Filters $\ldots \ldots \ldots \ldots \ldots \ldots \ldots . . \ldots .4$

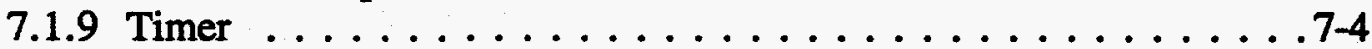

7.1.10 Instrument Enclosure $\ldots \ldots \ldots \ldots \ldots \ldots \ldots \ldots . \ldots \ldots$

7.2 ALARM SET POINTS $\ldots \ldots \ldots \ldots \ldots \ldots \ldots \ldots \ldots \ldots . \ldots \ldots$

7.2.1 Emissions Limits . . . . . . . . . . . . . . 7-8

7.2.2 Alarm Set Point Derivation . . . . . . . . . . 7-11

7.2.3 Determination of Alarm Set Points . . . . . . . . 7-18

7.2.4 Interpretation of Alarm Set Points . . . . . . . . . 7-23

7.3 SPECIFIC STACK SAMPLING/MONITORING INSTRUMENTATION 7-24

8.0 EMISSION DATA $\ldots \ldots \ldots \ldots \ldots \ldots \ldots \ldots \ldots \ldots \ldots \ldots \ldots \ldots \ldots$

9.0 SAMPLE ANALYSIS $\ldots \ldots \ldots \ldots \ldots \ldots \ldots \ldots \ldots \ldots$. . . . . . . . . . . . .

9.1 EFFLUENT SAMPLE EXCHANGE AND ANALYTICAL

LABORATORY PROCEDURES . . . . . . . . . . . . . 9-1

9.1.1 Airborne Effluent Sample Exchange Process . . . . . . . . . 9-1

9.1.2 Liquid Effluent Samples and Analyses . . . . . . . . . 9-6

9.2 SAMPLING AND DATA CHAIN OF CUSTODY . . . . . . . . 9-7

9.3 U.S. DEPARTMENT OF ENERGY ANALYTICAL AND LABORATORY GUIDELINES $\ldots \ldots \ldots \ldots \ldots \ldots \ldots \ldots$

10.0 NOTIFICATION AND REPORTING REQUIREMENTS . . . . . . . . . . 10-1

10.1 OCCURRENCE CATEGORIZATION, NOTIFICATION, AND

REPORTING . . . . . . . . . . . . . . . . . . 10-1

10.1.1 Occurrence Identification and Immediate Response . . . . . . . 10-1

10.1.2 Occurrence Categorization . . . . . . . . . . 10-2

10.2 OCCURRENCE CATEGORIZATION $\ldots \ldots \ldots \ldots \ldots \ldots \ldots \ldots$ 10-2

10.2.1 Radioactive Releases . . . . . . . . . . . . . . . 10-2

10.2.2 Release of Hazardous Substances/Regulated Pollutants/Oil . . . 10-3

10.2.3 Discovery of Hazardous Material Contamination

Due to DOE Operations . . . . . . . . . . . . 10-5

10.2.4 Agreement/Compliance Activities . . . . . . . . . 10-5

10.2.5 Ecological Resources . . . . . . . . . . . . . . 10-7

10.3 FEDERAL REQUIREMENTS $\ldots \ldots \ldots \ldots \ldots \ldots \ldots \ldots \ldots$ 10-7

10.3.1 Resource Conservation and Recovery Act of 1976 . . . . . . 10-7

10.3.2 Comprehensive Environmental Response, Compensation

and Liability Act of $1980 \ldots \ldots$. . . . . . . . . . . . 
CONTENTS (Continued)

10.3.3 National Emission Standards for Hazardous Air Pollutants . . . 10-8

10.4 STATE REQUIREMENTS $\ldots \ldots \ldots \ldots \ldots \ldots \ldots \ldots \ldots \ldots$ 10-8

10.4.1 Generator Reporting . . . . . . . . . . . . . 10-8

10.4.2 Facility Reporting . . . . . . . . . . . . . . . 10-8

10.5 U.S. DEPARTMENT OF ENERGY REQUIREMENTS . . . . . . . . 10-8

10.5.1 U.S. Department of Energy Order 5400.1, Chapter II General

Environmental Protection Program -

Notification and Reports . . . . . . . . . . . . . 10-8

10.5.2 U.S. Department of Energy Order 5484.1

Environmental Protection, Safety and

Health Protection Information

Reporting Requirements . . . . . . . . . . . . . . . . . . 10-9

11.0 INTERFACE WITH THE OPERATIONAL ENVIRONMENTAL

MONITORING PROGRAM $\ldots \ldots \ldots \ldots \ldots \ldots \ldots \ldots \ldots \ldots \ldots \ldots \ldots$

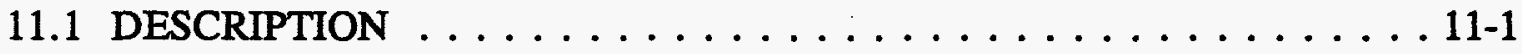

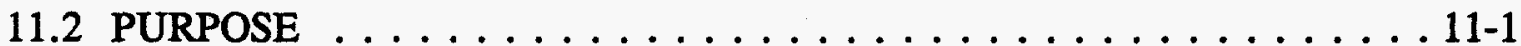

11.3 BASIS . . . . . . . . . . . . . . . . . . . 11-4

11.4 MEDIA SAMPLED AND ANALYSES PERFORMED $\ldots \ldots \ldots \ldots 11-4$

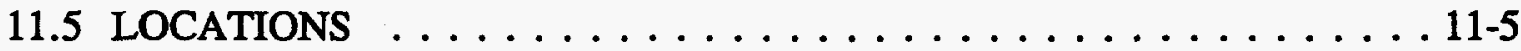

11.6 PROGRAM REVIEW $\ldots \ldots \ldots \ldots \ldots \ldots \ldots \ldots \ldots \ldots \ldots$

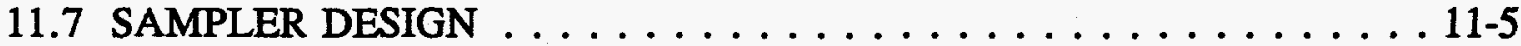

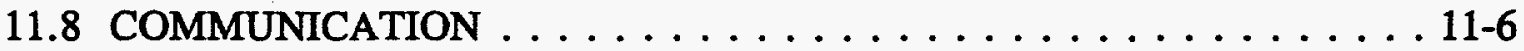

11.9 REPORTS . . . . . . . . . . . . . . . . 11-6

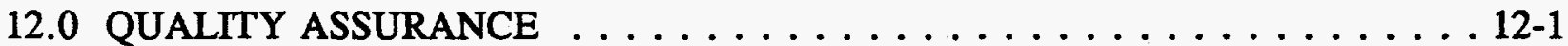

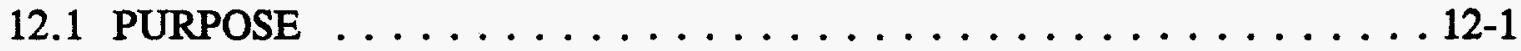

12.2 OBJECTIVE . . . . . . . . . . . . . . . . 12-1

12.3 REQUIREMENTS . . . . . . . . . . . . . . . . . . 12-1

12.4 FACILITY-SPECIFIC REQUIREMENTS $\ldots \ldots \ldots \ldots \ldots \ldots \ldots 12-2$

13.0 INTERNAL AND EXTERNAL PLAN REVIEW . . . . . . . . . . 13-1

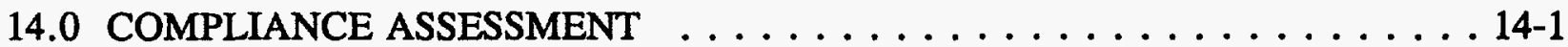

14.1 COMPLIANCE ASSESSMENT $\ldots \ldots \ldots \ldots \ldots \ldots \ldots \ldots \ldots \ldots$ 14-2

14.1.1 The 296-A-22 Stack (242-A Evaporator Vessel Vent) . . . . . . 14-2

14.1.2 The $296-\mathrm{A}-40$ Stack . . . . . . . . . . . . . . . . 14-2

14.1.3 The $296-\mathrm{A}-17$ Stack . . . . . . . . . . . . . . . . . 14-2

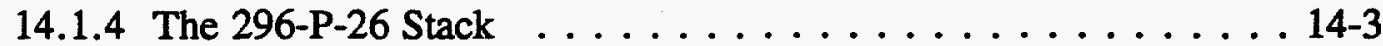

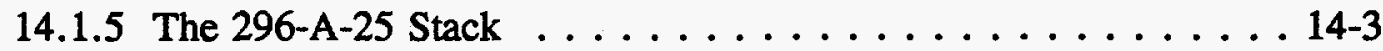

14.1.6 The $296-A-27$ Stack . . . . . . . . . . . . . . . . 14-3

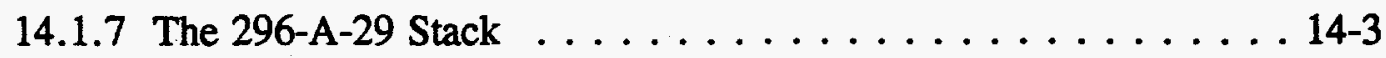




\section{CONTENTS (Continued)}

14.1.8 The 296-B-28 Stack $\ldots \ldots \ldots \ldots \ldots \ldots \ldots$. . . . . . . . . . . .

14.1.9 The $296-$ C-5 Stack . . . . . . . . . . . . . . . . . . . 14-4

14.1.10 The 296-P-16 Stack . . . . . . . . . . . . . . . . 14-4

14.1.11 The 296-P-23 Stack . . . . . . . . . . . . . . . . 14-5

14.1.12 The 296-P-28 Stack . . . . . . . . . . . . . . 14-5

14.1.13 The $296-$ S-15 Stack . . . . . . . . . . . . . . . 14-5

14.1.14 The $296-$ S-22 Stack . . . . . . . . . . . . . . . . 14-6

14.1.15 The $296-\mathrm{T}-18$ Stack $\ldots \ldots \ldots \ldots \ldots \ldots \ldots \ldots \ldots$. . . . . . . . . . . .

14.1.16 The 296-U-11 Stack . . . . . . . . . . . . . . . . . . . 14-6

14.2 CORRECTIVE ACTIONS REQUIRED FOR COMPLIANCE $\ldots \ldots \ldots$ 14-7

14.2.1 Discussion of Deficiencies . . . . . . . . . . . 14-7

15.0 SUMMARY AND CONCLUSIONS $\ldots \ldots \ldots \ldots \ldots \ldots \ldots \ldots \ldots$ 15-1

15.1 FEDERAL FACILITY COMPLIANCE AGREEMENT $\ldots \ldots \ldots \ldots 15-1$

15.2 SUMMARY OF CURRENT DEFICIENCIES $\ldots \ldots \ldots \ldots \ldots \ldots$ 15-1

15.3 FUTURE USE/EXISTING UPGRADES PLANS . . . . . . . . . . 15-6

15.3.1 Stacks Being Replaced by W-030 Project . . . . . . . . 15-6

15.3.2 Stacks Planned for Replacement by W-420 Project . . . . . . 15-6

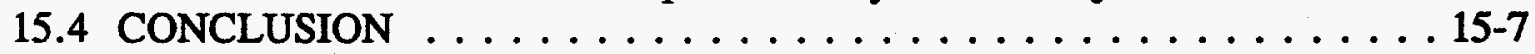

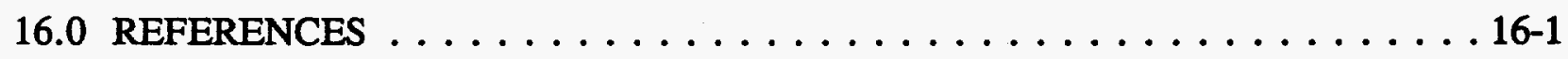


WHC-EP-0479-1

\section{LIST OF FIGURES}

2-1 Waste Tank Locations. . . . . . . . . . . . . . . . . . . 2-4

2-2 Hanford Tank Farm Facilities. . . . . . . . . . . . . . . .

2-3 Typical Double-Shell Tank Cross Section . . . . . . . . . . . . . . . . . . 2-9

7-1 Composite Generic Monitor/Sampler Instrument Enclosure $\ldots \ldots \ldots \ldots$. . . 7-6 


\section{LIST OF TABLES}

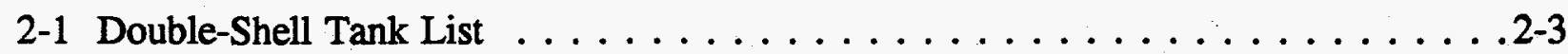

2-2 Tank Number and Type of Waste Stored in Million-Gallon Non-Aging Double-Shell Tanks . . . . . . . . . . . . . . . . 2-7

2-3 Tank Number and Type of Waste Stored in Million-Gallon Aging Waste Double-Shell Tanks . . . . . . . . . . . . . . 2-8

3-1 Applicable Regulations and Standards $\ldots \ldots \ldots \ldots \ldots \ldots \ldots \ldots \ldots$ 3-2

4-1 Comparison of Potential and Actual Emissions $\ldots \ldots \ldots \ldots \ldots$ 4-3

4-2 Significant Radionuclide Contributors to Potential EDE . . . . . . . . . . . . . . 4-4

7-1 Emission Limits $\ldots \ldots \ldots \ldots \ldots \ldots \ldots \ldots \ldots \ldots \ldots \ldots \ldots \ldots \ldots \ldots$

7-2 CAM Alarm Set Point $\ldots \ldots \ldots \ldots \ldots \ldots \ldots \ldots \ldots \ldots$ 7-20 . . . . . . . . .

7-3 Stack 296-A-17: 241-AY/AZ Tank Farms Exhauster Beta/gamma Loop . . . . . . . . . . . . . . . . . 7-25

7-4 Stack 296-A-17: 241-AY/AZ Tank Farms Exhauster Record Sampler Loop . . . . . . . . . . . . . . . . . 7-25

7-5 Stack 296-P-26: 241-AY/AZ Tank Farms Backup Exhauster Beta/gamma Loop . . . . . . . . . . . . . . . . 7-25

7-6 Stack 296-P-26: 241-AY/AZ Tank Farms Backup Exhauster Record Sampler Loop . . . . . . . . . . . . . . . . . . 7-25

7-7 Stack 296-A-25: 244-A Double-Contained Receiver Tank Exhauster Beta/gamma Loop $\ldots \ldots \ldots \ldots \ldots \ldots \ldots \ldots \ldots \ldots \ldots \ldots \ldots \ldots$ 7-26

7-8 Stack 296-A-25: 244-A Double-Contained Receiver Tank Exhauster Record Sampler Loop . . . . . . . . . . . . . . . . 7-26

7-9 Stack 296-A-27: 241-AW Tank Farm Exhauster - Beta/gamma Loop . . . . . . 7-26

7-10 Stack 296-A-27: 241-AW Tank Farm Exhauster - Record Sampler Loop . . . 7 7-26

7-11 Stack 296-A-29: 241-AN Tank Farm Exhauster - Beta/gamma Loop . . . . . . 7-27

7-12 Stack 296-A-29: 241-AN Tank Farm Exhauster - Record Sampler Loop . . . 7-27 


\section{LIST OF TABLES (Continued)}

7-13 Stack 296-A-40: 241-AP Tank Farm Exhauster - Beta/gamma Loop . . . . . . 7-27

7-14 Stack 296-A-40: 241-AP Tank Farm Exhauster - Record Sampler Loop . . . . . 7-27

7-15 Stack 296-B-28: 244-BX Double Contained Receiver Tank

Exhauster - Record Sampler Loop $\ldots \ldots \ldots \ldots \ldots \ldots$. . . . . . . . . . . . .

7-16 Stack 296-C-05: 244-CR Vault Exhauster - Beta/gamma Loop . . . . . . . . . . 7-28

7-17 Stack 296-C-05: 244-CR Vault Exhauster - Record Sampler Loop . . . . . . . 7-28

7-18 Stack 296-P-16: 241-C-105/106 Tank Exhauster - Beta/gamma Loop . . . . . 7-28

7-19 Stack 296-P-16: 241-C-105/106 Tank Exhauster -

Record Sampler Loop . . . . . . . . . . . . . . . . . . . . . . . . . . . . . 7-29

7-20 Stack 296-P-23: 241-SY Tank Farm Exhauster - Beta/gamma Loop . . . . . . 7-29

7-21 Stack 296-P-23: 241-SY Tank Farm Exhauster -

Record Sampler Loop . . . . . . . . . . . . . . . . . . . . . . . . . . 7-29

7-22 Stack 296-P-28: 241-SY Tank Farm Backup Exhauster - Alpha Loop . . . . . 7-29

7-23 Stack 296-P-28: 241-SY Tank Farm Backup Exhauster - Beta/gamma Loop . . 7-30

7-24 Stack 296-P-28: 241-SY Tank Farm Backup Exhauster -

Record Sampler Loop . . . . . . . . . . . . . . . . . . . 7-30

7-25 Stack 296-S-15: 241-SX Tank Farm Exhauster - Beta/gamma Loop . . . . . . 7-30

7-26 Stack 296-S-15: 241-SX Tank Farm Exhauster -

Record Sampler Loop . . . . . . . . . . . . . . . . . . . 7-30

7-27 Stack 296-S-22: 244-S Double-Contained Receiver Tank Exhauster -

Record Sampler, Alpha, and Beta/Gamma Parallel Loops . . . . . . . . . . 7-31

7-28 Stack 296-T-18: 244-TX Double-Contained Receiver Tank Exhauster -

Record Sampler, Alpha, and Beta/Gamma Parallel Loop . . . . . . . . . 7-31

7-29 Stack 296-U-11: 244-U Double Contained Receiver Tank Exhauster -

Record Sample, Beta/Gamma Parallel Loops . . . . . . . . . . . . . 7-32 


\section{LIST OF TABLES (Continued)}

9-1 200 East Tank Farm Effluent Data Processing Codes . . . . . . . . . . . 9-2

9-2 200 West Tank Farm Effluent Data Processing Codes $\ldots \ldots \ldots . . \ldots$. . . . . .

9-3 Minimum Quantifiable Activities for Specific Radionuclides as Measured in Air Samples Changed Weekly . . . . . . . . . . . 9-5

9-4 Data Analyses and Statistical Treatment $\ldots \ldots \ldots \ldots \ldots \ldots . . \ldots$ 9-9

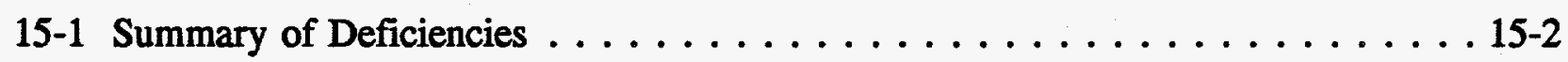

15-2 Emissions, Measurement Errors, and Collection Efficiencies $\ldots \ldots \ldots \ldots$ 15-3

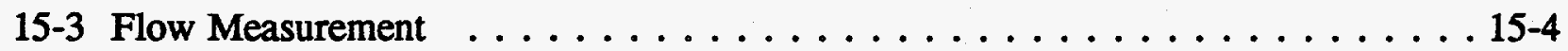

15-4 Sample Probe and Sample Analysis . . . . . . . . . . . . . 15-5 
This page intentionally left blank. 


\section{LIST OF TERMS}

\begin{tabular}{ll} 
AEA & Atomic Energy Act of 1954 \\
ALARA & As Low As Reasonably Achievable \\
ANSI & American National Standards Institute \\
APCA & Air Pollution Control Authority \\
ASF & Ammonia Scrubber Feed \\
ASP & Alarm Setpoints \\
ASTM & American Society for Testing and Materials \\
ATP & Acceptance Test Procedure \\
CAM & Continuous Air Monitoring \\
CERCLA & Comprehensive Environmental Response, Compensation \\
& Liability Act of 1980 \\
CFR & Code of Federal Regulations \\
DAC & Derived Air Concentration \\
DCRT & Double-Contained Receiver Tanks \\
DOE & U.S. Department of Energy \\
DST & Double-Shell Tank \\
EDE & Effective Dose Equivalent \\
EDP & Electronic Data Processing \\
EMP & Environmental Monitoring Plan \\
EMS & Effluent Monitoring System \\
EPA & U.S. Environmental Protection Agency \\
FEMP & Facility Effluent Monitoring Plan \\
FFCA & Federal Facility Compliance Agreement \\
HEPA & High Efficiency Particulate Air \\
HPT & Health Physics Technician \\
HWVP & Hanford Waste Vitrification Plant \\
ICRP & International Commission of Radiation Protection \\
NESHAP & National Emission Standards for Hazardous Air Pollutants \\
NPDES & National Pollution Discharge Elimination System \\
OEMP & Operational Environmental Monitoring Program \\
PFP & Plutonium Finishing Plant \\
POTW & Publicly Owned Treatment Works \\
PSD & Prevention of Significant Deterioration Permit \\
PUREX & Plutonium/Uranium Extraction \\
RCRA & Resource Conservation and Recovery Act of 1976 \\
RHO & Rockwell Hanford Operations \\
SAR & Safety Analysis Report \\
SARA & Superfund Amendments and Reauthorization Act of 1986 \\
SST & Single-Shell Tank \\
TSD & Treatment, Storage, or Disposal \\
WAC & Washington Administrative Code \\
WHC & Westinghouse Hanford Company \\
& \\
\hline
\end{tabular}


WHC-EP-0479-1

This page intentionally left blank. 


\subsection{INTRODUCTION}

A variety of liquid wastes are generated in processing treatment, and disposal operations throughout the Hanford Site. The Tank Farms Project serves a major role in Hanford Site waste management activities as the temporary repository for these wastes. Stored wastes include hazardous components regulated under the Resource Conservation and Recovery Act of 1976 (RCRA) and as by-product material regulated under the Atomic Energy Act of 1954.

A total of 177 single- and double-shell tanks (SSTs and DSTs) have been constructed in the 200 East and 200 West Areas of the Hanford Site. These facilities were constructed to various designs from 1943 to 1986 . The Tank Farms Project is comprised of these tanks along with various transfer, receiving, and treatment facilities.

\subsection{POLICY}

It is the policy of the U.S. Department of Energy (DOE) and Westinghouse Hanford Company (WHC) to conduct effluent monitoring that is adequate to determine if the public and environment are protected during DOE Operations, and if operations are in compliance with DOE and other applicable federal, state, and local radiation and hazardous material standards and requirements. It is also DOE and Westinghouse Hanford's policy that effluent monitoring programs meet high standards of quality and credibility.

Facility Effluent Monitoring Plans (FEMP) are required for facilities: (1) if the total projected effective dose equivalent (EDE) to any member of the public from radionuclide emissions at the facility exceeds $0.1 \mathrm{mrem} / \mathrm{yr}$ from any one discharge point; (2) if any one regulated material discharged over a $24-\mathrm{h}$ period from a facility exceeds $100 \%$ of the Comprehensive Environmental Response, Compensation, and Liability Act of 1980 (CERCLA) reportable quantity as listed in 40 Code of Federal Regulations (CFR) Part 302.4 (U.S. Environmental Protection Agency); or (3) if a liquid effluent is regulated by the National Pollutant Discharge Elimination System (NPDES) and contains radionuclides that will cause any person consuming that effluent to receive an EDE greater than 4.0 millirem per year.

This FEMP was prepared in accordance with $A$ Guide for Preparing Hanford Site Facility Effluent Monitoring Plans (WHC 1992), and is intended to be a standalone document which details the effluents, the effluent discharge points, the monitoring systems, the sampling protocol, and the controls at the facility with data and information, incorporated by reference. 


\subsection{PURPOSE}

The purpose of this FEMP is to fulfill the General Environmental Protection Program DOE Order 5400.1 (DOE 1990a) that requires a FEMP for each Hanford Site tank farm facility that contains hazardous materials, that could effect employee and public safety and/or the environment.

\subsection{SCOPE}

This document includes a program plan for monitoring and characterizing radioactive and nonradioactive hazardous materials discharged in the tank farm facility effluents. This plan includes documentation for gaseous and liquid effluent monitoring systems (EMS) for radioactive and nonradioactive hazardous pollutants that could be discharged under routine and/or upset conditions. This FEMP describes the airborne and liquid effluent paths and the associated sampling and monitoring systems for the tank farm facilities. It also provides information on the effluent characteristics and the effluent monitoring systems for use in assessing compliance with requirements. Adequate details are supplied so that radioactive and hazardous material source terms may be related to specific effluent streams. These, in turn, are related to discharge points and finally, compared to the effluent monitoring system capability.

Tank farm facilities evaluated to need a FEMP included the DST Farms, the SST Farms, the 204-AR Unloading Station, the 244-CR Vault, and the Double-Contained Receiver Tanks. The results of the evaluations for all of these facilities are included in Facility Effluent Monitoring Plan Determinations for the 200 Area Facilities (WHC 1991a). Waste transfer lines between facilities (i.e., between waste tanks to/from processing facilities) also were evaluated. No upset scenarios considered for these lines would produce a release requiring a FEMP.

Descriptions of sampling and monitoring systems for the SSTs are not provided in this FEMP (with the exception of the 296-P-16 and 285-S-15 stacks). The SSTs were taken out of service because of questionable integrity and the number of known leakers. No new wastes have been added to the SSTs since 1981, and the flow of dangerous waste into the tank system has been stopped. Current activities support the ultimate closure of the SST system and include interim stabilization (removal of liquids) and interim isolation of tanks. This work is done according to a compliance plan identified as part of the Hanford Federal Facility Agreement and Consent Order of 1990 (commonly called the Tri-Party Agreement) (Ecology et al. 1994). Leakage from the SSTs is not considered an effluent for this plan and is monitored as part of an environmental surveillance program established by the Westinghouse Hanford Environmental Protection group.

Underground solvent storage tanks are not included in this FEMP. There were no tanks identified in the references or by cognizant Westinghouse Hanford staff which would be considered part of the tank farm facilities. 


\subsection{FACILITY DESCRIPTION}

This section includes brief descriptions of the tank farm facilities and the processes used at the facilities. The tank farms, as part of the 200 Area facilities, are discussed with emphasis placed on the DSTs and the related processes for those tank farms. For those facilities of interest as discussed within this FEMP, a thorough description is provided in the various Safety Analysis Reports (SAR) as follows:

WHC-SD-WM-SAR-016, Rev. 1, Double Shell Tank Farm Facility Safery Analysis Report (WHC 1986a) includes:

- 241-AW Tank Farm

- 241-AN Tank Farm

- 241-AP Tank Farm

- 241-SY Tank Farm.

WHC-SD-WM-SAR-010, Rev. 2, Aging Waste Facility Safety Analysis Report (WHC 1989b) includes:

- 241-AY Tank Farm

- 241-AZ Tank Farm.

WHC-SD-WM-SAR-032, Rev. 0, Safety Analysis Report for Salt Well Receiver Facilities (Hanson et al. 1980) includes:

- 244-A Double Contained Receiver Tank (DCRT)

- 244-BX DCRT

- 244-CR Vault

- 244-S DCRT

- 244-TX DCRT

- 244-U DCRT.

WHC-SD-WM-SAR-006, Rev. 2, Single Shell Tank Isolation Safety Analysis Report (WHC 1986b) includes:

- 241-C-105/106 Tank

- 241-SX Tank Farm. 


\subsection{FACILITY PHYSICAL DESCRIPTION}

\subsubsection{Tank Farms as Part of the 200 Area Facilities}

Figure 2-1 shows the general locations for all of the tank farms in the 200 East and 200 West Areas. Both DSTs and SSTs are shown. Tank Farms in the 200 East Area include the A, $\mathrm{AX}, \mathrm{B}, \mathrm{BX}, \mathrm{BY}, \mathrm{C}$ (SSTs), AN, AZ, AY, AP, and AW (DSTs). Those in the 200 West Area are the S, SX, T, TX, TY, U (SSTs), and the SY (DST) Tank Farms. Figure 2-1 also shows the locations for T Plant, U Plant, the 222-S Laboratory, B Plant, Plutonium/Uranium Extraction (PUREX) Plant, and the Plutonium Finishing Plant (PFP).

Figure 2-2 is a schematic diagram showing the Hanford Site tank farm facilities and the transfer routes, diversion boxes, storage vaults, double-contained receiver tanks, and evaporators within the overall system. Information on the type and/or status (i.e., single-shell, double-shell, assumed leaker, interim stabilized), tank number monitoring instrumentation, etc., is included in the diagram (Hanlon 1991).

A system of underground pipes is used to transfer wastes from the 200 East Area waste generators to the DSTs, between the DSTs, and from the DSTs to treatment and storage units in the 200 East and 200 West Areas. Two major types of transfer lines are used in the DST System. The older lines are generally 5.1- to $10.2-\mathrm{cm}$ (2- to 4-in.) diameter carbon or stainless steel pipe(s) in a concrete encasement. Newer transfer lines usually consist of a 5.1- to 10.2-cm (2- to 4-in.) diameter carbon steel (sometimes stainless steel) pipe encased in a 15.2-cm (6-in.) diameter carbon steel (sometimes stainless steel) pipe. Stainless steel pipe is used for lines that transfer potentially acidic waste or that may carry a variety of waste types. Encasements can be changed from pipe-in-pipe encasements to concrete encasements when new lines are tied to old ones.

\subsubsection{Double-Shell Waste Tanks}

The DSTs in this FEMP are presented in Table 2-1. The DSTs discussed are of two distinctly different types. The first type consists of $3.79-$ to $4.54-\mathrm{ML}$ (1.0- to $1.2-\mathrm{Mgal})$ DSTs designed for long-term storage (up to $50 \mathrm{yr}$ ) of high-activity mixed waste.

For efficiency during construction and operation, the million-gallon tanks were grouped into six tank farms with each tank farm having $2,3,6,7$, or 8 tanks. At the Hanford Site, all buildings, tanks, and other engineered structures are given an alpha-numeric designation, e.g., 241-SY-103. The 241 indicates that the structure is associated with a tank farm. The SY indicates that the tank is located in the SY Tank Farm. The 103 is the individual tank number within the SY Tank Farm. The DSTs in each tank farm generally are numbered starting with 101. The 241-SY Tank Farm is located in the west-central portion of the 200 West Area and consists of three 3.79-ML (1-Mgal) tanks. The five other DST farms are located in the east-central part of the 200 East Area. The 241-AY Tank Farm consists of 
Table 2-1. Double-Shell Tank List.

\begin{tabular}{|c|c|c|}
\hline Tank Number & Location & Operation Date \\
\hline There are twenty-four 1.2 Mgal Non-Aging Double-Shell Tanks (DSTs). \\
\hline \hline 241-AN-101 & 200 East Area & $09 / 81$ \\
241-AN-102 & 200 East Area & $09 / 81$ \\
241-AN-103 & 200 East Area & $09 / 81$ \\
241-AN-104 & 200 East Area & $09 / 81$ \\
241-AN-105 & 200 East Area & $09 / 81$ \\
241-AN-106 & 200 East Area & $09 / 81$ \\
241-AN-107 & 200 East Area & $09 / 81$ \\
\hline 241-AP-101 & 200 East Area & $10 / 86$ \\
241-AP-102 & 200 East Area & $10 / 86$ \\
241-AP-103 & 200 East Area & $10 / 86$ \\
241-AP-104 & 200 East Area & $10 / 86$ \\
241-AP-105 & 200 East Area & $10 / 86$ \\
241-AP-106 & 200 East Area & $10 / 86$ \\
241-AP-107 & 200 East Area & $10 / 86$ \\
241-AP-108 & 200 East Area & $10 / 86$ \\
\hline $241-A W-101$ & 200 East Area & $08 / 80$ \\
241-AW-102 & 200 East Area & $08 / 80$ \\
241-AW-103 & 200 East Area & $08 / 80$ \\
241-AW-104 & 200 East Area & $08 / 80$ \\
241-AW-105 & 200 East Area & $08 / 80$ \\
241-AW-106 & 200 East Area & $08 / 80$ \\
\hline 241-SY-101 & 200 West Area & $04 / 77$ \\
241-SY-102 & 200 West Area & $04 / 77$ \\
241-SY-103 & 200 West Area & $04 / 77$ \\
\hline There are four 1.0 Mgal Aging Waste Double-Shell Tanks (DSTs). \\
\hline \hline 241-AY-101 & 200 East Area & $07 / 71$ \\
241-AY-102 & 200 East Area & $04 / 76 *$ \\
\hline 241-AZ-101 & 200 East Area & $11 / 76$ \\
241-AZ-102 & 200 East Area & $11 / 76$ \\
\hline
\end{tabular}

*Estimated date the tank became operational. 


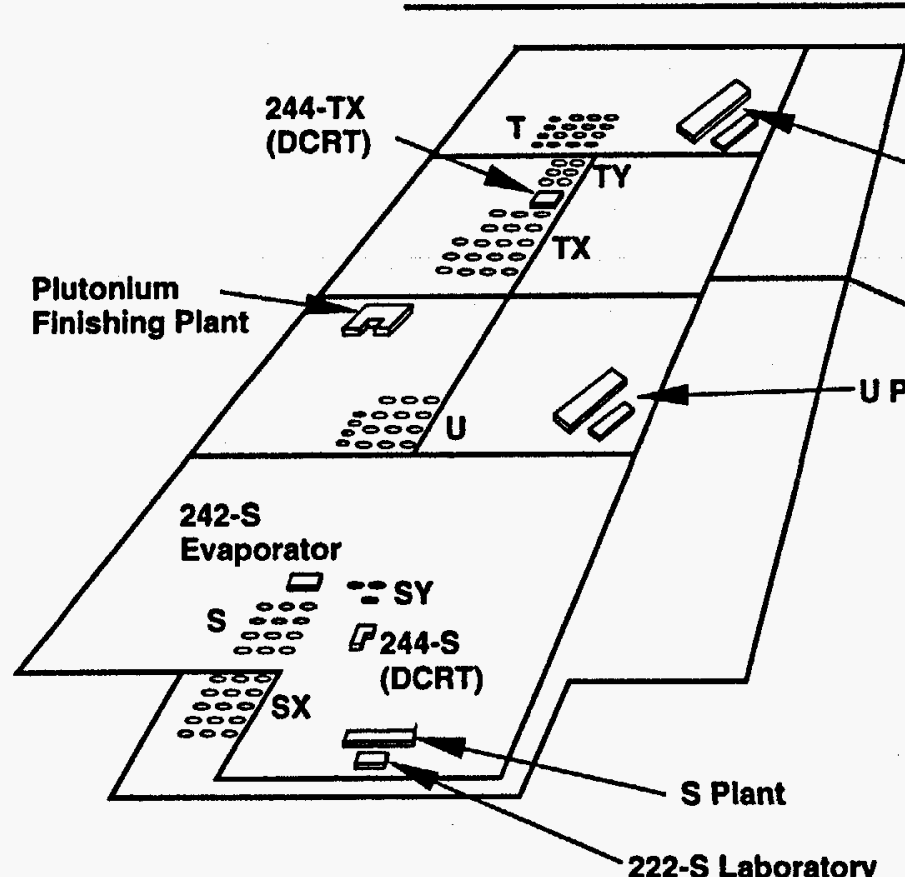

200 West Area

$$
\begin{aligned}
& \text { Underground Waste Tanks } \\
& \text { (Designated by Tank Farms) } \\
& ==\text { Double-shell tank } \\
& \text { O }=\text { Single-shell tank } \\
& \text { DCRT }=\begin{array}{l}
\text { Double-containment } \\
\text { recelver tank }
\end{array}
\end{aligned}
$$

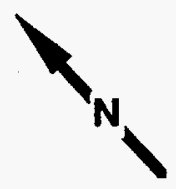

B Plant

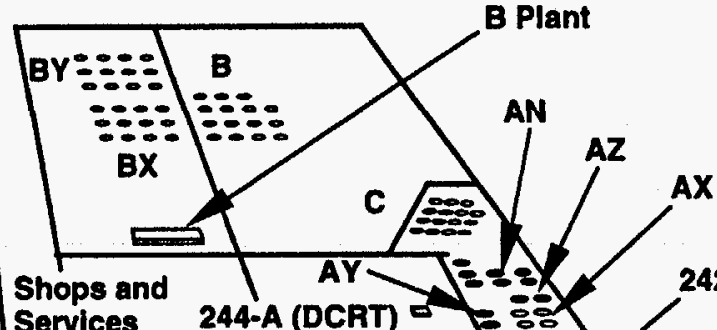

Shops and

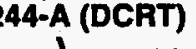

42-A Evaporator

AP

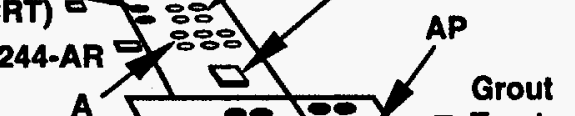

Grout Facility (DCRT)
(D-W-151

Warehouses 2750 East Bullding

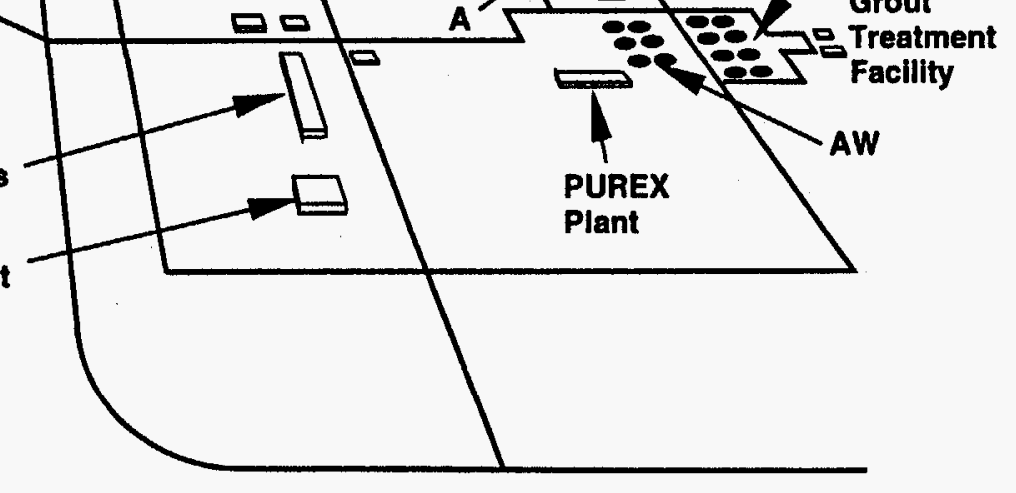

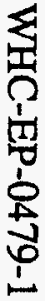


Figure 2-2. Hanford Tank Farm Facilities.

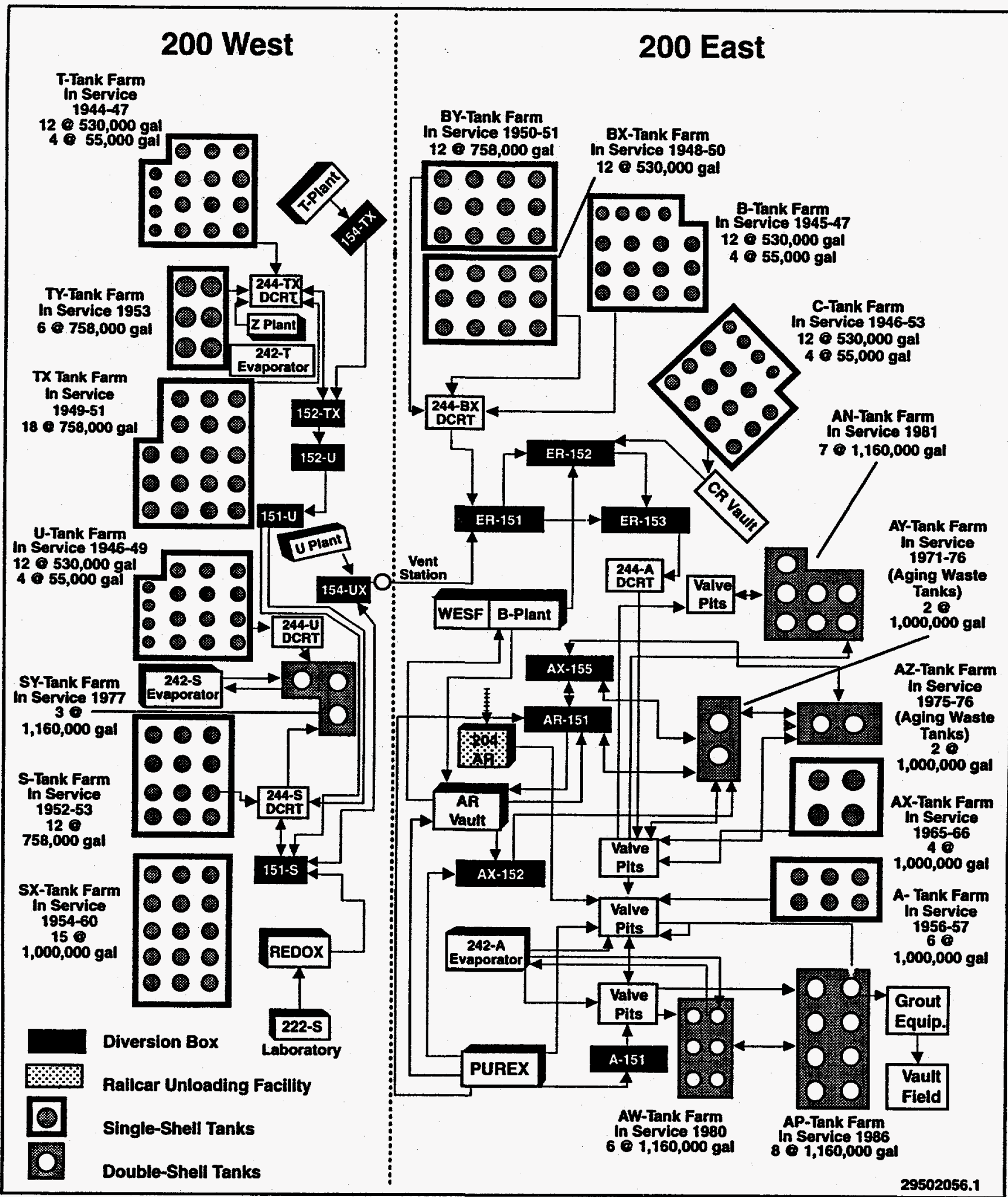


two tanks; the 241-AZ Tank Farm consists of two tanks; the 241-AW Tank Farm consists of six tanks; the 241-AN Tank Farm consists of seven tanks; and the 241-AP Tank Farm consists of eight tanks.

The second type of tank consists of the smaller, 3,000- to $170,000-\mathrm{L}$ (800- to 45,000 -gal) tanks used primarily for lag storage of waste before transfer to the larger tanks or to other facilities. These smaller tanks are DCRTs.

The DSTs were fabricated as three concentric tanks. Waste is stored in the free standing primary tank which is $22.9 \mathrm{~m}(75 \mathrm{ft})$ in diameter and $14.2 \mathrm{~m}(46.8 \mathrm{ft})$ high at the crown. The primary tank sits on a concrete insulating pad. The secondary tank, $1.5 \mathrm{~m}(5 \mathrm{ft})$ larger in diameter than the primary tank, creates a surrounding space called the annulus. The secondary tank sits on a concrete pad. The completely enclosed annulus serves as a containment barrier if the primary tank should leak. The annulus is ventilated and continually monitored for evidence of primary tank leakage. The third tank is a concrete shell that encloses the sides of both primary and secondary tanks for additional containment, radiation shielding, and structural support. Figure 2-3 illustrates a typical DST cross section.

This FEMP includes ancillary equipment, such as transfer lines between tank farms and/or DCRTs, associated valve pits, diversion boxes, and tank farm piping.

\subsection{PROCESS DESCRIPTION}

The DST farms store waste from:

- PUREX Plant

- PFP

- B Plant

- T Plant

- 222-S Laboratory

- 100 Areas

- 300 Areas

- 400 Areas

- Single-shell tanks.

A maximum "operating volume" of $106 \mathrm{ML}$ (28 Mgal) of waste can be stored in the 28 DSTs in the 6 tank farms. Thus, maximum "operating volume" is less than the maximum physical volume of all of the tanks of about $119 \mathrm{ML}(31.5 \mathrm{Mgal})$.

This allows for realistic operating conditions (e.g., self-boiling in the aging tanks, frothing, mixing, agitation). No offsite waste is accepted for storage.

Tables 2-2 and 2-3 show the types of waste stored in non-aging and aging tanks. 
Table 2-2. Tank Number and Type of Waste Stored in Million-Gallon Non-Aging Double-Shell Tanks. (2 sheets)

\begin{tabular}{|c|c|c|}
\hline Tank number & Waste stream source & Type of waste stored in tank \\
\hline 241-AN-101 & 244-BX & Single-shell tank saltwell waste \\
\hline 241-AN-102 & B-Plant & $\begin{array}{l}\text { Complexed concentrate waste (waste } \\
\text { encapsulation) }\end{array}$ \\
\hline 241-AN-103 & 242-A Evaporator & Double-shell slurry waste \\
\hline 241-AN-104 & 242-A Evaporator & Double-shell slurry feed waste \\
\hline 241-AN-105 & PUREX & Neutralized cladding removal waste \\
\hline 241-AN-106 & 100 Area & Concentrate phosphate waste \\
\hline 241-AN-107 & B Plant & $\begin{array}{l}\text { Complexed concentrate waste (waste } \\
\text { encapsulation) }\end{array}$ \\
\hline 241-AP-101 & 241-AP-103/G7 & Ammonia scrubber feed (ASF) (PUREX) \\
\hline 241-AP-102 & 100 Area & Phosphate and sulfate waste \\
\hline 241-AP-103 & PUREX & Ammonia scrubber feed \\
\hline 241-AP-104 & 100 Area & Phosphate and sulfate waste \\
\hline 241-AP-105 & 241-AW-106/241-AP-106 & $\begin{array}{l}\text { Double-shell slurry feed and noncomplexed } \\
\text { (242-A Evaporator) waste }\end{array}$ \\
\hline 241-AP-106 & 241-AY-102/241-AW-106 & $\begin{array}{l}\text { Double-shell slurry feed and noncomplexed } \\
\text { (242-A Evaporator) waste }\end{array}$ \\
\hline 241-AP-107 & PUREX & Process distillate discharge \\
\hline 241-AP-108 & PUREX & Process distillate discharge \\
\hline 241-AW-101 & Single-shell tanks & $\begin{array}{l}\text { Dilute noncomplexed waste } \\
\text { Single-shell tank saltwell waste }\end{array}$ \\
\hline 241-AW-102 & 244-A/A-350 catch tank & $\begin{array}{l}\text { Evaporator feed tank, double-shell slurry } \\
\text { feed ( } 242-\mathrm{A} \text { Evaporator) }\end{array}$ \\
\hline $241-A W-103$ & PUREX & Neutralized cladding removal waste \\
\hline 241-AW-104 & $\begin{array}{l}\text { PUREX F-18, U-3, U-4, } \\
\text { G-8, R-8 }\end{array}$ & Dilute noncomplexed waste \\
\hline 241-AW-105 & PUREX & Neutralized cladding removal waste \\
\hline
\end{tabular}


Table 2-2. Tank Number and Type of Waste Stored in Million-Gallon Non-Aging Double-Shell Tanks. (2 sheets)

\begin{tabular}{|c|l|l|}
\hline Tank number & \multicolumn{1}{|c|}{ Waste stream source } & \multicolumn{1}{|c|}{ Type of waste stored in tank } \\
\hline 241-AW-106 & 242-A Evaporator & $\begin{array}{l}\text { Double-shell slurry feed } \\
\text { Single-shell tank saltwell }\end{array}$ \\
\hline $241-S Y-101$ & $\begin{array}{l}\text { Single-Shell tanks } \\
\text { 242-S Evaporator }\end{array}$ & $\begin{array}{l}\text { Double-shell slurry feed } \\
\text { Single-shell tank saltwell, complexed waste }\end{array}$ \\
\hline $241-S Y-102$ & $\begin{array}{l}\text { 244-TX-DCRT, } \\
\text { 244-S-DCRT }\end{array}$ & $\begin{array}{l}\text { Cross-site waste, single-shell tank saltwell, } \\
\text { Plutonium Finishing Plant waste }\end{array}$ \\
\hline $241-S Y-103$ & $\begin{array}{l}\text { 242-S Evaporator } \\
\text { TK-C-100, 244-S }\end{array}$ & $\begin{array}{l}\text { Uranium sludge waste, double-shell slurry, } \\
\text { complexed waste }\end{array}$ \\
\hline
\end{tabular}

DCRT $=$ Double-Contained Receiver Tanks.

PUREX = Plutonium/Uranium Extraction Plant.

Table 2-3. Tank Number and Type of Waste Stored in Million-Gallon Aging Waste Double-Shell Tanks.

\begin{tabular}{|l|l|l|}
\hline Tank number & \multicolumn{1}{|c|}{ Waste stream source } & \multicolumn{1}{|c|}{ Type of waste stored in tank } \\
\hline 241-AY-101 & NDA & $\begin{array}{l}\text { Strontium- and cesium-bearing waste, } \\
\text { depleted high-level waste, dilute } \\
\text { noncomplexed waste, dilute complexed } \\
\text { waste }\end{array}$ \\
\hline 241-AY-102 & $\begin{array}{l}\text { AX-152 catch tank, 204-AR } \\
\text { waste unloading station }\end{array}$ & $\begin{array}{l}\text { Neutralized high-level waste, A-417 catch } \\
\text { tank, double-shell slurry feed, dilute } \\
\text { B-Plant 25-1 NCPLX, noncomplexed } \\
\text { waste }\end{array}$ \\
\hline 241-AZ-101 & PUREX & Neutralized current acid waste \\
\hline 241-AZ-102 & PUREX & Neutralized current acid waste \\
\hline
\end{tabular}

NDA $=$ No data available. 


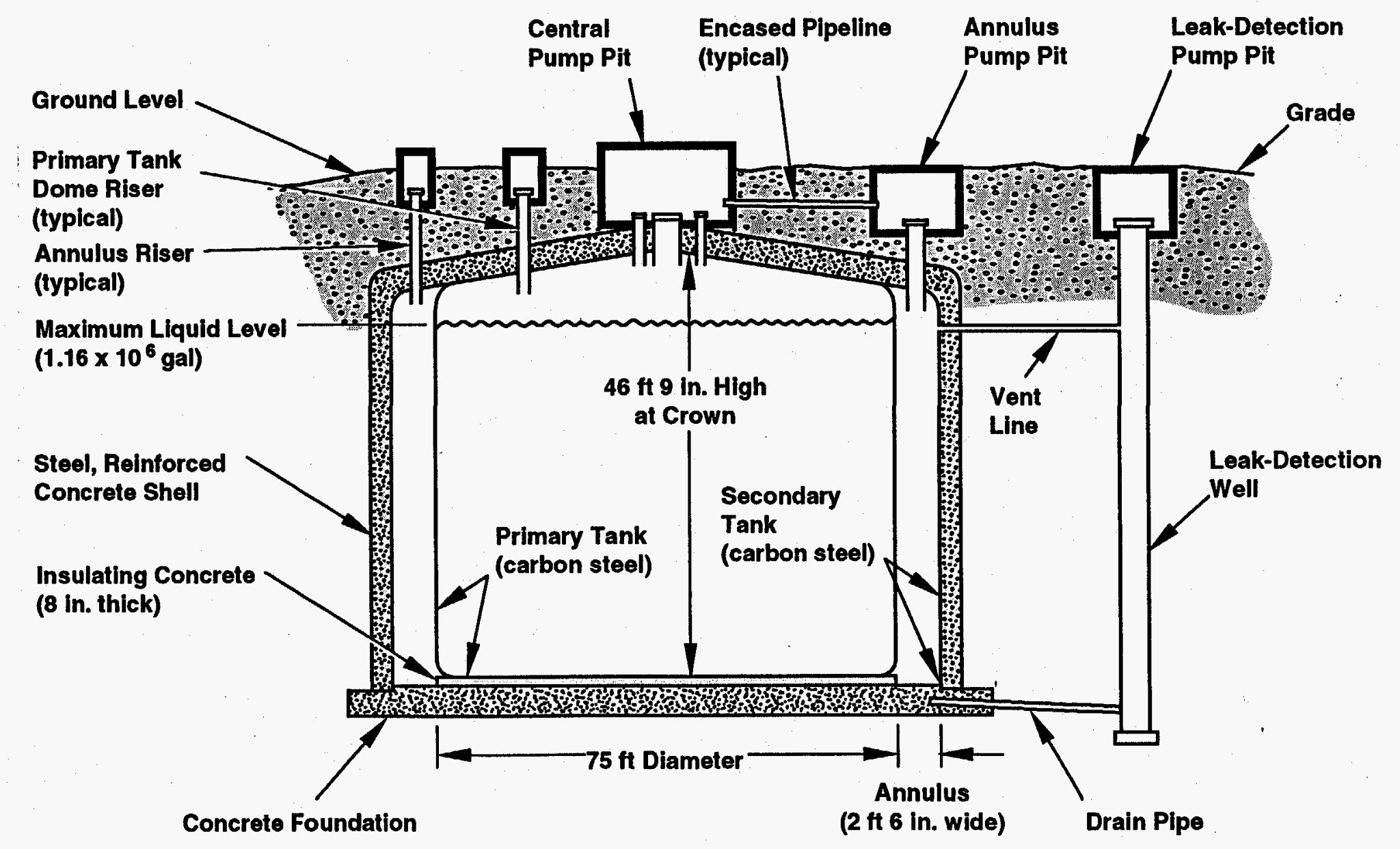


Waste composition, degree of radioactivity, and source location determine which tank is selected to store specific wastes. Some waste streams are combined in one DST, particularly when the waste stream volume and the potential for chemical interaction are small.

Waste from the 100,300 , and 400 Areas generally is transported to the 200 East Area in railroad tank cars. The waste enters the DST System at the 204-AR Waste Unloading Station, located north of the PUREX Plant. The 204-AR Building is also equipped to receive waste shipments by truck.

Characterization of wastes in DSTs generally is based on generator knowledge and records or other information from its point of origin. As stated in Double-Shell Tank System Dangerous Waste Permit Application, DOE/RL-90-39 (DOE/RL 1990), EPA protocols were not used in most of the limited analyses that have been performed. Hanford Site laboratories are currently modifying procedures to meet EPA protocols. However, all waste contained in DSTs has been analyzed to some extent for both hazardous and radioactive materials.

The waste stored in the DSTs is a mixed waste containing both radioactive and hazardous chemical components as defined by the Atomic Energy Act of 1954 and RCRA. The DST waste consists primarily of sodium hydroxide, sodium salts of nitrate, nitrite, carbonate, aluminate, phosphate, and hydrous oxides of iron and manganese. The radioactive part of the mixed waste includes various types and concentrations of radioactive constituents including high-level, transuranic, and low-level waste. These radioactive components consist primarily of fission products (e.g. ${ }^{90} \mathrm{Sr},{ }^{137} \mathrm{Cs}$, and $\left.{ }^{129} \mathrm{I}\right)$ and actinide elements (e.g., uranium, americium, plutonium, and neptunium).

The RCRA-regulated components of the mixed waste have several potential waste classifications, including primarily RCRA characteristics (e.g., corrosivity [D002] and TCLP toxicity [F003/F005] for various metals). The dangerous waste classifications of toxic, persistent, carcinogenic, and extremely hazardous waste, pursuant to Dangerous Waste Regulations, Washington Administrative Code (WAC) 173-303, also are potential designations for waste stored in the DSTs based on the presence of low concentrations of solvents and high concentrations of heavy metals.

Although the DSTs contain mostly inorganic waste, small amounts of organics may be present. The presence of regulated organics in the waste may be a result of chemical breakdown or recombination of organic complexing agents, laboratory and research work, or solvents that may have been added during fuel reprocessing procedures.

Waste stored in the DSTs is designated as corrosive, toxic, persistent, carcinogenic, and extremely hazardous waste in accordance with WAC 173-303.

The 28 DSTs are currently at about $75 \%$ of their $106 \mathrm{ML}$ (28 Mgal) maximum "operating" storage capacity. Space for $7.6 \mathrm{ML}(2 \mathrm{Mgal})$ is kept in reserve for contingencies (i.e., half of which is for aging waste, the other half is for non-aging waste). This effectively raises the $75 \%$ to about $83 \%$. PUREX Plant is normally the largest contributor of waste that is 
transferred to the DSTs. However, PUREX is in a non-processing mode and is generating greatly reduced volumes of waste. The volumes of waste generated at individual sites and transferred to the DSTs varies greatly. For example, during early 1990, B Plant transferred approximately $212,000 \mathrm{~L}(56,000 \mathrm{gal})$ to the DSTs per month. T Plant transferred approximately $793,600 \mathrm{~L}(209,700 \mathrm{gal})$ during 1988 . These numbers are provided for general information only.

Future plans call for the retrieval and treatment of waste stored in the DST system. After treatment, the low-activity fraction of the waste will be vitrified at the Low-Level Waste Vitrification Plant. The high-activity and transuranic portions of the waste will be vitrified at the High-Level Waste Vitrification Plant and sent offsite for disposal in a national repository.

In general, the majority of the waste stored in the DSTs is generated by the PUREX process. Facilities that currently (or had) produce(d) and transfer(red) waste to the DSTs include the following:

- PUREX Plant

- $\quad$ PUREX neutralized cladding removal waste

- PUREX neutralized current acid waste from the first extraction column (aging-waste)

- $\quad$ PUREX Tank F-18 miscellaneous waste

- $\quad$ PUREX Tanks U3 and U4 miscellaneous waste

- PUREX ammonia scrubber waste.

- Plutonium Finishing Plant

- Transuranic sludge

- Low-level processing waste supernatant

- 242-A Evaporator concentrated double-shell slurry and double-shell feed (the 242-A Evaporator is addressed in a separate FEMP).

- $\quad$ B Plant

- Concentrated complexed waste and noncomplexed waste (currently not being generated)

- Cell drainage and vessel cleanout waste. 
- S Plant laboratory and decontamination waste

- T Plant decontamination solutions

- 300 Area laboratory and fuel fabrication waste

- 400 Area laboratory waste

- 100 Area

- Dilute phosphate reactor decontamination waste

- 100 Area spent fuel storage basin sulfate waste (from ion exchange regeneration and sand filter backwashing).

- $\quad$ Single-shell tank saltwell waste.

Waste from historical chemical process operations also is transferred to the DSTs. Before 1980, this waste was stored in SSTs. Liquid supernatant from the SSTs has been and is being transferred to the DSTs. 


\subsection{APPLICABLE REGULATIONS}

Conditions and requirements for monitoring existing or potential releases of radioactive and other chemicals to the environment are contained in DOE orders and federal, state, and local laws and regulations. Table 3-1 gives a brief summary of the regulations and standards applicable to this FEMP.

\subsection{U.S. DEPARTMENT OF ENERGY ORDERS}

\subsubsection{U.S. Department of Energy Order 5400.1}

The DOE Order 5400.1, General Environmental Protection Program (DOE 1990a), requires a written environmental monitoring plan for each site, facility, or process that uses, generates, releases, or manages significant pollutants or hazardous materials. The plan must include the rationale and design criteria for the monitoring program, as well as describe the extent and frequency of the monitoring analysis. The plan also must contain Quality Assurance (QA) requirements, program implementation procedures, directions for preparation and implementation of reports, and directions for identification and discussion of effluent monitoring and environmental surveillance.

The effluent monitoring portion of the plan must verify compliance with applicable regulations and DOE orders. It also should evaluate the effectiveness of treatment; identify potential environmental problems; evaluate the need for remedial action or mitigation measures; support permit revision and/or reissuance; and detect, characterize, and report unplanned releases.

\subsubsection{U.S. Department of Energy Order 5400.5}

The DOE Order 5400.5 (DOE 1990c) requires a monitoring plan that complies with the requirements of DOE Order 5400.1. Compliance with the requirements of DOE Order 5400.5 may be demonstrated based on calculations from monitoring and surveillance programs information. 
Table 3-1. Applicable Regulations and Standards. (3 sheets)

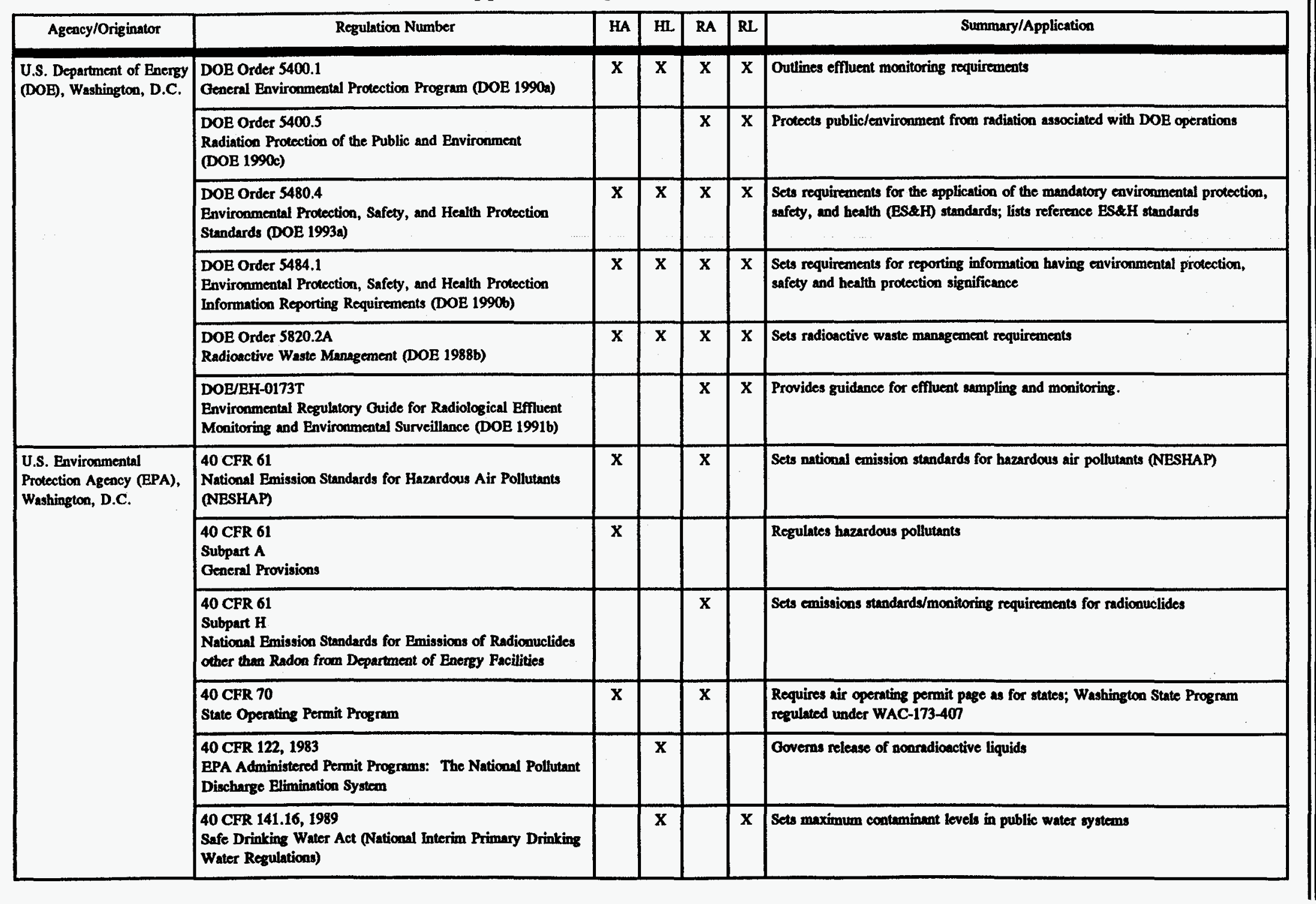


Table 3-1. Applicable Regulations and Standards. (3 sheets)

\begin{tabular}{|c|c|c|c|c|c|c|}
\hline Agency/Originator & Regulation Number & HA & HL & RA & $\mathbf{R L}$ & Summary/Application \\
\hline \multirow[t]{5}{*}{ EPA (Cont'd) } & $\begin{array}{l}40 \text { CFR } 191 \\
\text { Disposal of Spent Nuclear Fuel, High-Level and Transuranic } \\
\text { Radioactive Wastes }\end{array}$ & & & & $\mathbf{x}$ & Regulates radioaclive waste disposal \\
\hline & $\begin{array}{l}40 \text { CFR } 261 \\
\text { Identification and Listing of Hazardous Waste }\end{array}$ & & $\mathbf{x}$ & & & Identifies and lists hazardous wastes \\
\hline & $\begin{array}{l}40 \text { CFR } 302.4 \\
\text { Comprehensive Eavironmental Response, Compensation and } \\
\text { Liability Act of } 1980 \text { (CERCLA): Designation, Reportable } \\
\text { Quantities and Notification }\end{array}$ & $\mathbf{x}$ & $\mathbf{x}$ & $\mathbf{x}$ & $\mathbf{x}$ & Designates hazardous materials, reportable quantities, notification process \\
\hline & $\begin{array}{l}40 \text { CFR } 355 \\
\text { Superfund Amendments and Reauthorization Act of } 1986 \\
\text { (SARA): Emergency Planning and Notification }\end{array}$ & $\mathbf{x}$ & $\mathbf{x}$ & & & Identifies threshold planning quantities for extremely hazardous substances \\
\hline & $\begin{array}{l}40 \text { CFR } 403-471 \\
\text { Effluent Guidelines Standards }\end{array}$ & & $\mathbf{x}$ & & & Sets pretreatment standards for waste water discharge to owned lands publicly. \\
\hline \multirow[t]{2}{*}{$\begin{array}{l}\text { American National } \\
\text { Standards Institute, (ANSI) } \\
\text { New York, New York }\end{array}$} & $\begin{array}{l}\text { N } 13.1^{*}-1969 \\
\text { Guidance to Sampling Airbome Radioactive Materials in } \\
\text { Nuclear Facilities }\end{array}$ & & & $\mathbf{x}$ & & Sets standards for effluent monitoring systems \\
\hline & $\begin{array}{l}\text { N } 42.18^{*}, 1974 \\
\text { Specification and Performance of On-site Instrumentation for } \\
\text { Continuously Monitoring Radioactivity in Effluents }\end{array}$ & & & $\mathbf{x}$ & $\mathbf{x}$ & $\begin{array}{l}\text { Recommendations for the selection of instrumentation for the monitoring of } \\
\text { radioactive effluents }\end{array}$ \\
\hline \multirow{4}{*}{$\begin{array}{l}\text { Washington State } \\
\text { Department of Ecology, } \\
\text { (Bcology) Olympia, } \\
\text { Washington }\end{array}$} & $\begin{array}{l}\text { WAC 173-216 } \\
\text { State Waste Discharge Permit Program }\end{array}$ & & $\mathbf{x}$ & & & Governs discharges to ground and surface waters \\
\hline & $\begin{array}{l}\text { WAC 173-220 } \\
\text { National Pollutant Discharge Elimination system Permit }\end{array}$ & & $\mathbf{x}$ & & $\mathbf{x}$ & $\begin{array}{l}\text { Governs waste water discharges to navigable waterways; controls National } \\
\text { Pollution Discharge Elimination System (NPDES) permit process }\end{array}$ \\
\hline & $\begin{array}{l}\text { WAC 173-240 } \\
\text { Submission of Plans and Reports for Construction of Waste } \\
\text { Water Pacilities }\end{array}$ & & $\mathbf{x}$ & & & Controls release of nouradioactive liquids \\
\hline & $\begin{array}{l}\text { WAC 173-303 } \\
\text { Dangerous Waste Regulations }\end{array}$ & & $\mathbf{x}$ & & & Regulates dangerous wastes; prohibits direct release to soil columns \\
\hline
\end{tabular}


Table 3-1. Applicable Regulations and Standards. (3 sheets)

\begin{tabular}{|l|l|l|l|l|l|l|l|}
\hline \multicolumn{1}{|c|}{ Agency/Originator } & \multicolumn{1}{|c|}{ Regulation Number } & HA & HI & RA & RL & \\
\hline Ecology (Cont'd) & $\begin{array}{l}\text { WAC 173-400 } \\
\text { General Regulations for Air Pollution Sources }\end{array}$ & $\begin{array}{l}\text { WAC 173-401 } \\
\text { Air Operating Permit Program }\end{array}$ & $\begin{array}{l}\text { WAC 173-460 } \\
\text { 1991 Control for New Sources of Toxic Air Pollutants }\end{array}$ & Xets emissions standards for hazardous air pollutants \\
\hline & $\begin{array}{l}\text { WAC 173-480 } \\
\text { 1990 Washington State Ambient Air Quality Standard and } \\
\text { Emission Limits for Radionuclides }\end{array}$ & X & & X & & Endorses the 10-mrem/yr EDE-EPA standards (40 CFR 61, Subpant H) \\
\hline $\begin{array}{l}\text { Washington State } \\
\text { Department of Health, } \\
\text { Olympia, Washington }\end{array}$ & $\begin{array}{l}\text { WAC 246-247, 1994 } \\
\text { Radiation Protection - Air Emissions }\end{array}$ & radionuclides
\end{tabular}

*Refers to standards that are referenced in the DOE and EPA regulations.

$\mathbf{R A}=$ radioactive aiborne.

HIL $=$ hazardous liquid.

$\mathbf{R L}=$ radioactive liquid. 


\subsection{FEDERAL REGULATIONS}

\subsubsection{Environmental Protection Agency Regulations on National Emission Standards for Hazardous Air Pollutants $\mathbf{4 0}$ Code of Federal Regulations 61}

Subpart H, "National Emission Standards for Emissions of Radionuclides Other Than Radon from Department of Energy Facilities," (40 CFR 61) establishes exposure limits and monitoring requirements. The exposure limits, for members of the public, from radionuclide emissions is an EDE not to exceed $10 \mathrm{mrem} /$ year. Compliance with this standard is measured by calculating the highest EDE where a person resides or abides using an EPA-approved method.

Emissions of radionuclides must be measured at all release points that have a potential to discharge radionuclides into the air in quantities that could cause an EDE in excess of $1 \%$ of the standard. If the EDE caused by all emissions is less than 1\% of the standard, the facility is exempt from the EPA monitoring requirements. All radionuclides that could contribute greater than $10 \%$ of the potential EDE for a release point shall be measured individually. With prior EPA approval, DOE may determine these emissions through alternative procedures. For other release points that have a potential to release radionuclides into the air, periodic confirmatory measurements shall be made to verify low emissions.

To determine whether a release point is subject to emission measurement requirements, it is necessary to evaluate the potential for radionuclide emissions for that release point. In evaluating the potential of a release point to discharge radionuclides into the air, the estimated radionuclide release rates shall be based on the discharge of the effluent stream that would result if all pollution control equipment did not exist, but the facility operations were otherwise normal.

Subpart $\mathrm{H}$ also states that effluent streams shall be directly monitored continuously with an in-line detector or representative samples of the effluent stream shall be withdrawn continuously from the sampling site following the guidance presented in American National Standards Institute (ANSI) N13.1 (ANSI 1969). The requirements for continuous sampling are applicable to batch processes when the unit is in operation. Periodic sampling (grab samples) may be used only with EPA's prior approval. Such approval may be granted in cases where continuous sampling is not practical and radionuclide emission rates are relatively constant. In such cases, grab samples shall be collected with sufficient frequency to provide a representative sample of the emissions. 


\subsubsection{Reportable Quantities 40 Code of Federal Regulations 302}

The regulations in 40 CFR 302 designate hazardous substances and identify reportable quantities and notification requirements for releases of these hazardous substances under the Comprehensive Environmental Response, Compensation, and Liability Act (CERCLA) of 1980 and the Safe Drinking Water Act of 1974, as amended.

Any unpermitted release of any of these designated hazardous substances must be reported. Therefore, if the possibility exists for a facility to release any of the designated substances, waste streams must be monitored for their presence and monitoring practices must be provided in a FEMP.

\subsection{STATE REGULATIONS}

\subsubsection{Washington State Ambient Air Quality Standard and Emission Limits for Radionuclides WAC-173-480}

Although the standard for Washington (WAC 173-480) establishes a $25 \mathrm{mrem} / \mathrm{yr}$ EDE for public exposure to radionuclide emissions, facilities must comply with the most restrictive of federal, state or local law. Therefore, the exposure limit that must be complied with is $10 \mathrm{mrem} / \mathrm{yr}$; however, compliance is calculated at the point of maximum annual air concentration in an unrestricted area where any member of the public may be located (fence boundary).

\subsubsection{Groundwater Protection}

Radionuclides are defined as hazardous air pollutants, so they also will be construed to be hazardous in liquid effluent, without any specific listing of individual radionuclides as a hazardous substance under water pollution control laws.

"Water Quality Standards For Groundwaters of the State of Washington" (WAC 173-200) protects groundwater to the level of drinking water standards. These standards limit exposures to gross alpha, gross beta, tritium, ${ }^{90} \mathrm{Sr}$, and ${ }^{226,228} \mathrm{Ra}$. For radionuclides that are not specifically listed, exposures are limited by the federal standard to an EDE not to exceed $4 \mathrm{mrem} / \mathrm{yr}$. 


\subsubsection{Dangerous Waste Regulations}

Any release of a dangerous waste or hazardous substance (as designated by Washington State Administrative Code [WAC] 173-303) to the environment, except permitted releases, must be reported. Waste streams that have the potential to contain dangerous waste constituents must be monitored accordingly.

\subsection{LOCAL REGULATIONS}

\subsubsection{Benton, Franklin, and Walla Walla Counties Air Pollution Control Authority}

The local air pollution control authority has jurisdiction over all air emissions except radionuclide emissions in the Benton, Franklin, and Walla Walla county areas, including the Hanford Site. Currently, there are no local standards more restrictive than the previously mentioned state and federal limits; therefore state and federal standards apply.

\subsection{AIR EMISSIONS}

The DOE Order 5400.5 (DOE 1990c) provides requirements for the monitoring of radioactive and nonradioactive airborne effluents from DOE facilities at the Hanford Site. This order states that DOE-controlled facilities must comply with 40 CFR 61 .

Additional EPA requirements on hazardous substances are contained in 40 CFR Part 302.A. This regulation provides information on reportable quantities of nonradioactive hazardous substances. Unlisted hazardous substances designated by 40 CFR Part 302.4 are regulated in accordance with the EPA toxicity of the contaminant.

In Washington State, airborne effluents are regulated by the Department of Ecology through regulations in the WAC, Title 173, Chapters 173-400 through 173-490, as amended, pursuant to the Washington Clean Air Act (RCW, Title 70, Public Health and Safety Chapter 94, as amended). General regulations for air pollution sources are presented in WAC 173-400, including emission standards for sources emitting hazardous air pollutants found in WAC 173-400-075.

WAC 246-247, "Radiation Protection Air Emissions," specifies new source review, notification, registration, and permitting requirements associated with any source of radioactive air emissions in Washington State, including those on the Hanford Site. One requirement listed in WAC 246-247 is the semiannual (twice yearly) reporting of emissions from each registered stack or vent on site. By agreement with the Washington State Department of Health, only annual reporting is required. 
WAC 173-480, "Ambient Air Quality Standards and Emission Limits for Radionuclides," defines maximum allowable levels for radionuclides in the ambient air and defines required levels for control of emissions.

While both the WAC 246-247 and 173-480 list outdated maximum EDE standards, each contains a caveat stating that a more stringent federal standards take precedence over the EDE standard specified by the WAC. Therefore, each effectively endorses the $10 \mathrm{mrem} / \mathrm{yr}$ EDE standard of 40 CFR 61, Subpart $H$.

Regulations, including DOE orders, state that DOE facilities must comply with the requirements set forth in the National Emission Standards for Hazardous Air Pollutants (NESHAP) (40 CFR 61). Other regulations (e.g., 40 CFR 52, "Approval and Promulgation of Implementation Plans," and DOE Orders 5400.1 [DOE 1990a], 5400.5 [DOE 1990c], DOE/EH-0173T [DOE 1991b], and 5484.1 [DOE 1990b] state that DOE facilities must comply with the applicable requirements set forth in the Clean Air Act of 1977.

\subsection{LIQUID EFFLUENTS}

Requirements limiting the exposure of the public to radioactive materials from DOE-controlled activities through the drinking water pathway are presented in DOE Order 5400.5, Chapter II, Paragraph 1.d. The radiological criteria of the public community drinking water standards of 40 CFR Part 141, "National Primary Drinking Water Regulations," are applicable to Steam and Water Utilities Operation 200 East and West Operations as the providers of potable water to the site under the Safe Drinking Water Act of 1974. It is the policy of DOE to provide an equivalent level of protection for all persons consuming water from a drinking water supply operated by, or for, the DOE. These systems shall not cause any persons consuming the water to receive an EDE greater than $4 \mathrm{mrem} / \mathrm{yr}$, excluding naturally occurring radionuclides. In addition, DOE facility operators shall ensure that the liquid effluents from DOE activities shall not cause private or public drinking water systems downstream of the facility discharge to exceed the drinking water radiological limits of 40 CFR Part 141.

Depending on where a liquid effluent (waste water) is discharged, certain regulations apply. These regulations are implemented through issuance of permits by federal, state, and/or local agencies. It is the responsibility of the facility, through the Richland Operations Office (RL), to apply for the permit appropriate to the effluent being discharged. Before applying for any permits, the applicant must know the source of waste water discharges and where the waste water is being discharged to. The following regulations apply based on where the waste water is discharged.

1. The 40 CFR 261(4)(b)(6) provides a hazardous waste exclusion for fly ash, bottom ash, slag waste, and flue gas emissions control waste generated primarily from combustion of gas or other fossil fuel. 
2. Washington State controls discharges to groundwater and surface water of the state, under WAC 173-216, and issues permits for such discharges. A permit of this type would be necessary for any discharges to land that could infiltrate to groundwater.

Each type of discharge permit identified will typically contain discharge limitations and monitoring requirements. However, the limitations and monitoring requirements will vary depending on the source and type of waste water being discharged. For instance, discharges to a publicly owned treatment works will be subject to pretreatment standards based on the production process that generated the waste water for those processes categorized by the EPA. Categorical processes are identified in 40 CFR 401-471. Specific limitations, monitoring, and reporting requirements have been promulgated for each categorical process. In addition to EPA's requirements, the state and local waste water treatment agencies may impose additional limitations, monitoring, and reporting requirements. Discharges to a navigable waterway also will be subject to certain standards based on the industrial process that generated the waste water; certain additional limitations are typically imposed in the National Pollutant Discharge Elimination System (NPDES) permit. In all cases, the specific pollutants to be monitored and the frequency of monitoring and reporting will be based on the applicable regulations and the language of the permit. 
WHC-EP-0479-1

This page intentionally left blank. 


\subsection{DENTIFICATION AND CHARACTERIZATION OF EFFLUENT STREAMS}

This section discusses source terms (radiological and non-radiological) for the DSTs that need to be considered as potential contributors to public (offsite) exposures and evaluated against instrumentation design criteria. Routine operational conditions and a hypothesized upset condition are presented.

\subsection{IDENTIFICATION AND CHARACTERIZATION OF SOURCE TERMS CONTRIBUTING TO EACH EFFLUENT STREAM}

This section provides information for the identification and characterization of the potential source terms associated with the DSTs. The source term information will be compared to information in 40 CFR Part 61, Appendix D, and 40 CFR 302.4.

Tables 2-2 and 2-3 list the types of waste stored in non-aging and aging DSTs. Also listed in these tables are the waste stream sources for each specific tank.

Radionuclide source terms and major contributors to the potential offsite dose are identified in Section 3.0 of WHC-SD-WM-EMP-031 (WHC 1994m).

\subsubsection{Emissions from Routine Operations}

This section characterizes the radionuclide air stream effluents from the applicable Tank Farm Stacks during normal operating conditions.

The method used is different from that used in Rev. 0 of this FEMP. The original method used to determine the Tank Farm emissions, as discussed in the Rev. 0 of this FEMP, was rejected by EPA. Since this was the case and since the NESHAP regulations require that the potential public EDE be established for each emission point on the Hanford site, the EDE assessment was re-accomplished for all Tank Farm stacks in WHC-SD-WM-EMP-031, Determination of NESHAP Status of Tank Farm Stacks Based on Calculations Using 40 CFR, Part 61, Appendix D Factors (WHC 1994m). WHC-SD-WM-EMP-031 used Appendix D factors in determining the potential EDE for the following reasons:

- The method was a regulatory given method. No specific approvals had to be acquired to use it. By regulation, use of any other method required regulatory approval.

- A method was needed that could be used in a variety of situations existing around Tank Farms. Appendix D is designed to be used in that way. 
- It is generally believed that the Appendix D method is extremely conservative. This is because the release fractions allowed are extremely conservative. The real purpose, however, in determining the potential public EDE was to determine if the potential existed to exceed $0.1 \mathrm{mrem} / \mathrm{yr}$. If the results were conservative, they would still be acceptable.

- It was not known if all the possible specific radionuclides were being measured. This affected the decision to use the real emission approach. Since it wasn't known if all possible radionuclides were being measured, then it wouldn't be known if the results using a decontamination factor of $3000^{\circ}$ (where $n$ is the number of HEPA filters in service) would be valid.

- It was not known how efficient the sampling systems were and if real emission data would give reasonable results. For instance, if the sampling collection efficiency was low, then the results using real emission data could be off significantly. This would raise questions in those cases where the potential EDE were close to the 0.1 mrem limit.

- The Appendix D method was tied to use of a source term and would prove beneficial in providing a basis for which specific radionuclides had to be measured.

- Other scientific methods were explored which based emissions on available source term. The results were not that much different from the results generated from the Appendix D method.

In use of Appendix D in WHC-SD-WM-EMP-031, the source term data presented were decayed to September 1993. After applying the appropriate CAP-88 conversion factors (Rhoads 1991) the resultant potential public EDE came to those values given in Table 4-1. In addition to these potential values, actual emissions are given as well. The actual emissions came from the most recent annual emission reports. A more complete listing of the emission reports are given in given in Section 8.0 of this FEMP.

\subsubsection{Radionuclide Emissions of Concern}

The regulations (40 CFR 61.93) requires continuous measurement of all radionuclides that could contribute $10 \%$ or greater to the potential public EDE if that particular emission point has the potential to cause an EDE of $0.1 \mathrm{mrem} / \mathrm{yr}$ or greater. The results given in WHC-SD-WM-EMP-031 (WHC 1994m) provide the first step, in a two step approach being used to determine what these $10 \%$ contributors are. The second step is to compare real emission data to what Appendix $D$ predicts. If any radionuclides are not present in this data, they will be eliminated from the future measurement process. Listed in Table 4-2 are the significant contributors given WHC-SD-WM-EMP-031 for each of the applicable stacks. 
Table 4-1. Comparison of Potential and Actual Emissions. (mrem/yr)

\begin{tabular}{|c|c|c|c|}
\hline \multirow[t]{2}{*}{ Stack } & \multicolumn{2}{|c|}{$\begin{array}{l}\text { Emissions } \\
\text { (mrem/yr) }\end{array}$} & \multirow[t]{2}{*}{ Report Reference } \\
\hline & Potential & Actual & \\
\hline $\begin{array}{c}296-A-17 \\
\& \\
296-P-26\end{array}$ & 226 & $1.28 \mathrm{E}-05$ & $\begin{array}{l}\text { DOE/RL-94-51 } \\
\text { (DOE/RL 1994) }\end{array}$ \\
\hline $296-A-25$ & 0.11 & $7.9 \mathrm{E}-09$ & $\begin{array}{l}\text { DOE/RL-92-30 } \\
\text { (DOE/RL 1992) }\end{array}$ \\
\hline $296-A-27$ & 148 & 4.12E-08 & DOE/RL-94-51 \\
\hline $296-A-29$ & 846 & 3.68E-09 & DOE/RL-94-51 \\
\hline $296-A-40$ & 0.21 & $2.3 \mathrm{E}-09$ & DOE/RL-94-51 \\
\hline $296-B-28$ & 0.16 & $7.4 \mathrm{E}-09$ & DOE/RL-94-51 \\
\hline 296-C-05 & 187 & $3.1 \mathrm{E}-07$ & DOE/RL-94-51 \\
\hline 296-P-16 & 1.68 & $4.66 \mathrm{E}-07$ & DOE/RL-94-51 \\
\hline $\begin{array}{c}296-\mathrm{P}-23 \\
\& \\
296-\mathrm{P}-28\end{array}$ & 10.5 & 2.92E-08 & DOE/RL-94-51 \\
\hline $296-S-15$ & 270 & 2.17E-09 & DOE/RL-94-51 \\
\hline $296-S-22$ & 0.34 & $7.7 \mathrm{E}-08$ & DOE/RL-92-30 \\
\hline $296-T-18$ & 0.18 & $1.54 \mathrm{E}-08$ & DOE/RL-94-51 \\
\hline 296-U-11 & 0.37 & * & $\mathbf{N} / \mathbf{A}$ \\
\hline
\end{tabular}

*This stack did not operate prior to 1995. 
Table 4-2. Significant Radionuclide Contributors to Potential EDE.

\begin{tabular}{|c|c|c|c|}
\hline Facility & Stack Number & Radionuclide & $\%$ Of Potential EDE \\
\hline 241-AY/AZ & $\begin{array}{l}296-A-17 \\
296-P-26\end{array}$ & $137-\mathrm{Cs}$ & 97.60 \\
\hline 244-A DCRT & $296-A-25$ & $\begin{array}{c}137-\mathrm{Cs} \\
239 / 240-\mathrm{Pu}\end{array}$ & $\begin{array}{c}\text { Varies depending } \\
\text { upon tanks being } \\
\text { pumped }\end{array}$ \\
\hline 241-AW & $296-A-27$ & $\begin{array}{c}137-\mathrm{Cs} \\
241-\mathrm{Am}\end{array}$ & $\begin{array}{l}83.82 \\
10.71\end{array}$ \\
\hline 241-AN & 296-A-29 & $\begin{array}{c}137-\mathrm{Cs} \\
241-\mathrm{Am}\end{array}$ & $\begin{array}{l}26.58 \\
67.34\end{array}$ \\
\hline 241-AP & $296-A-40$ & 241-Am & 93.78 \\
\hline 244-BX DCRT & 296-B-28 & $\begin{array}{c}137-\mathrm{Cs} \\
241-\mathrm{Am} \\
239 / 240-\mathrm{Pu}\end{array}$ & $\begin{array}{c}\text { Varies depending } \\
\text { upon tanks being } \\
\text { pumped }\end{array}$ \\
\hline 244-CR & $296-C-05$ & $\begin{array}{c}137-\mathrm{Cs} \\
\text { 89/90-Sr } \\
239 / 240-\mathrm{Pu} \\
241-\mathrm{Am}\end{array}$ & $\begin{array}{c}\text { Varies depending } \\
\text { upon tanks being } \\
\text { pumped }\end{array}$ \\
\hline $241-C$ & 296-P-16 & $\begin{array}{c}137-\mathrm{Cs} \\
239 / 240-\mathrm{Pu}\end{array}$ & $\begin{array}{l}53.75 \\
43.31\end{array}$ \\
\hline 241-SY & $\begin{array}{l}296-P-23 \\
296-P-28\end{array}$ & 137-Cs & 98.50 \\
\hline $241-S X$ & $296-S-15$ & $\begin{array}{l}89 / 90-\mathrm{Sr} \\
137-\mathrm{Cs} \\
241-\mathrm{Am}\end{array}$ & $\begin{array}{l}64.21 \\
10.01 \\
20.25\end{array}$ \\
\hline $244-S$ & $296-S-22$ & $\begin{array}{c}\text { 89/90-Sr } \\
137-\mathrm{Cs} \\
239 / 240-\mathrm{Pu} \\
241-\mathrm{Am}\end{array}$ & $\begin{array}{c}\text { Varies depending } \\
\text { upon tanks being } \\
\text { pumped }\end{array}$ \\
\hline 244-TX & $296-T-18$ & $\begin{array}{c}\text { 89/90-Sr } \\
137-\mathrm{Cs} \\
239 / 240-\mathrm{Pu}\end{array}$ & $\begin{array}{c}\text { Varies depending } \\
\text { upon tanks being } \\
\text { pumped }\end{array}$ \\
\hline 244-U & 296-U-11 & $\begin{array}{c}\text { 89/90-Sr } \\
137-\mathrm{Cs} \\
239 / 240-\mathrm{Pu}\end{array}$ & $\begin{array}{c}\text { Varies depending } \\
\text { upon tanks being } \\
\text { pumped }\end{array}$ \\
\hline
\end{tabular}




\subsection{HYPOTHESIZED UPSET CONDITION}

The realistic upset condition chosen for the DSTs is an over-pressurization event in which all air filtration systems are damaged and the exhausters continue to run for an additional 4 hours before shutdown. Using the data presented in Section 7.0 of the DST Safety Analysis Report, it was calculated that the quantity per tank of contaminants exhausted to the atmosphere in 4 hours with no controls in place would be:

$$
\begin{aligned}
& 0.018 \mathrm{Ci}^{90} \mathrm{Sr} \\
& 0.018 \mathrm{Ci}^{137} \mathrm{Cs} \\
& 2.7 \times 10^{-5} \mathrm{Ci}^{241} \mathrm{Am} .
\end{aligned}
$$

These source terms are based on a 4-hour release (AP Tank Farm) with no filtration at concentrations of $2.65 \times 10^{-5} \mu \mathrm{Ci} / \mathrm{cc}$ of ${ }^{90} \mathrm{Sr}$ and ${ }^{137} \mathrm{Cs}$, and $4 \times 10^{-8} \mu \mathrm{Ci} / \mathrm{cc}$ of ${ }^{241} \mathrm{Am}$. The AP Farm was used because it has the greatest number of DSTs. Using the radiation dose factors provided in Rhoads (1991), these releases equate to $0.0006,0.0004$, and $0.00026 \mathrm{mrem}$, respectively, and total 0.0013 mrem to the maximally exposed offsite individual. This scenario does not include the release of loose material in the ventilation ducts or in the failed filters. 
WHC-EP-0479-1

This page intentionally left blank. 


\subsection{EFFLUENT POINT OF DISCHARGE DESCRIPTION}

This section includes brief descriptions of the applicable effluent streams from the tank farm facilities, including DSTs, SSTs, the 244-CR Vault, and the DCRTs.

\subsection{AIR EFFLUENTS}

The airborne effluent discharge points associated with the applicable stacks and associated information are listed below.

HEPA filter configurations are listed according to the following notation:

$-\mathrm{H}-\mathrm{H}-\quad$ Denotes 2 HEPA filters in series.

$-2 \mathrm{H}-\quad$ Denotes $2 \mathrm{HEPA}$ filters in parallel.

\subsubsection{Stack 296-A-17; 241-AY and 241-AZ Tank Farm Exhaust}

This stack exhausts filtered, noncondensable vapors from waste storage tanks in 241-AY and -AZ Tank Farms.

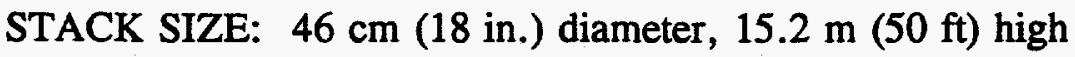

FAN DESIGN CAPACITY: Two, each rated at $113.3 \mathrm{~m}^{3} / \mathrm{min}\left(4,000 \mathrm{ft}^{3} / \mathrm{min}\right)$. Only one fan designed to run at a time. Fan Nos. are K1-1-1 and K1-1-2.

EMISSION CONTROL DEVICE: Filtration.

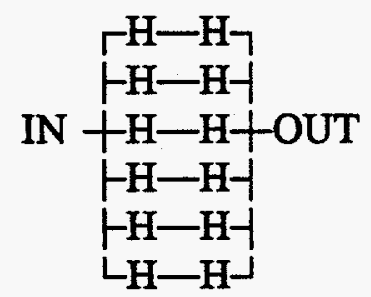

Stack flow rates are measured using Waste Tank Plant Maintenance Procedure 6-TF-155, Air Flow Test for Tank Farm Stacks and Ducts (WHC 1995a). 
AVERAGE

VARIABILITY

STANDARD DEVIATION

95\% CONFIDENT INTERVAL

RANGE
$92.3 \mathrm{~m}^{3} / \mathrm{min}\left(3,260 \mathrm{ft}^{3} / \mathrm{min}\right)$

$-16 \% /+13 \%$

$7.3 \mathrm{~m}^{3}\left(259 \mathrm{ft}^{3} / \mathrm{min}\right)$

$16.4 \mathrm{~m}^{3} / \mathrm{min}\left(578 \mathrm{ft}^{3} / \mathrm{min}\right) 18 \%$

75.95 to $108.7 \mathrm{~m}^{3} / \mathrm{min}\left(2,682\right.$ to $\left.3,838 \mathrm{ft}^{3} / \mathrm{min}\right)$

The location chosen for the measurement is specified in the guidance:

\subsubsection{Stack 296-P-26; 241-AY and -AZ Backup Tank Farm Exhaust}

This stack serves as backup to 296-A-17.

STACK SIZE: $41 \mathrm{~cm}(16 \mathrm{in}$.$) diameter, 3.1 \mathrm{~m}(10 \mathrm{ft})$ high

FAN DESIGN CAPACITY: $113.2 \mathrm{~m}^{3} / \mathrm{min}\left(4,000 \mathrm{ft}^{3} / \mathrm{min}\right)$. No fan number.

EMISSION CONTROL DEVICE: Filtration.

IN $-4 \mathrm{H}-4 \mathrm{H}-\mathrm{OUT}$

Stack flow rates are measured using Waste Tank Plant Maintenance procedure 6-TF-155, Air Flow Test for Tank Farm Stacks and Ducts (WHC 1995a).

$\begin{array}{ll}\text { AVERAGE } & 153.3 \mathrm{~m}^{3} / \mathrm{min}\left(5,412 \mathrm{ft}^{3} / \mathrm{min}\right) \\ \text { VARIABILITY } & -6 \% /+3 \% \\ \text { STANDARD DEVIATION } & 4.67 \mathrm{~m}^{3} / \min \left(165 \mathrm{ft}^{3} / \mathrm{min}\right) \\ \text { 95\% CONFIDENT INTERVAL } & 11.4 \mathrm{~m}^{3} / \mathrm{min}\left(403 \mathrm{ft}^{3} / \mathrm{min}\right)( \pm 7 \%) \\ \text { RANGE } & 141.8 \text { to } 164.7 \mathrm{~m}^{3} / \mathrm{min}\left(5,009 \text { to } 5,816 \mathrm{ft}^{3} / \mathrm{min}\right)\end{array}$

The location chosen for the measurement is specified in the guidance.

\subsubsection{Stack 296-A-25; 244-A Lift Station Catch Tank Exhaust}

This stack exhausts filtered air from the catch tank at the 244-A lift station.

STACK SIZE: $10 \mathrm{~cm}(4 \mathrm{in}$.$) diameter, 2.9 \mathrm{~m}(9.5 \mathrm{ft})$ high.

FAN DESIGN CAPACITY: $4.25 \mathrm{~m}^{3} / \mathrm{min}$ at $99^{\circ} \mathrm{C}\left(150 \mathrm{ft}^{3} / \mathrm{min}\right.$ at $\left.210^{\circ} \mathrm{F}\right)$. Fan No. is K1-5-1. 
EMISSION CONTROL DEVICE: Filtration.<smiles>N#CCN</smiles>

Stack flow rates are measured using Waste Tank Plant Maintenance Procedure 6-TF-155, Air Flow Test for Tank Farm Stacks and Ducts (WHC 1995a).
AVERAGE
VARIABILITY
$5.47 \mathrm{~m}^{3} / \mathrm{min}\left(193 \mathrm{ft}^{3} / \mathrm{min}\right)$
STANDARD DEVIATION
$-8 \% /+8 \%$
95\% CONFIDENT INTERVAL
$0.42 \mathrm{~m}^{3} / \mathrm{min}\left(15 \mathrm{ft}^{3} / \mathrm{min}\right)$
RANGE
$1.1 \mathrm{~m}^{3} / \mathrm{min}\left(40 \mathrm{ft}^{3} / \mathrm{min}\right)(21 \%)$
4.33 to $6.60 \mathrm{~m}^{3} / \mathrm{min}$ (153 to $233 \mathrm{ft}^{3} / \mathrm{min}$ )

The location chosen for the measurement is specified in the guidance.

\subsubsection{Stack 296-A-27; 241-AW Tank Farm Exhaust}

This stack exhausts filtered air from all 241-AW waste storage tanks.

STACK SIZE: $25 \mathrm{~cm}\left(10 \mathrm{in}\right.$.) diameter, $4.8 \mathrm{~m}^{3} / \mathrm{min}(15.8 \mathrm{ft})$ high.

FAN DESIGN CAPACITY: Two fans, each rated at $28.32 \mathrm{std} . \mathrm{m}^{3} / \mathrm{min}$ at $21^{\circ} \mathrm{C}$ $\left(1,000 \mathrm{std}\right.$. $\mathrm{ft}^{3} / \mathrm{min}$ at $70^{\circ} \mathrm{F}$. Normally, only one fan operates at a time. However, both fans can run at once. Fan Nos. are K1-5-1 and K1-5-2.

EMISSION CONTROL DEVICE: Filtration.<smiles>CCOO[I-]CC</smiles>

Stack flow rates are measured using Waste Tank Plant Maintenance Procedure 6-TF-155, Air Flow Test for Tank Farm Stacks and Ducts (WHC 1995a).
AVERAGE
VARIABILITY
$29.48 \mathrm{~m}^{3} / \mathrm{min}\left(1,041 \mathrm{ft}^{3} / \mathrm{min}\right)$
STANDARD DEVIATION
$-11 \% /+20 \%$
95\% CONFIDENT INTERVAL
$3.09 \mathrm{~m}^{3} / \mathrm{min}\left(109 \mathrm{ft}^{3} / \mathrm{min}\right)$
RANGE
$7.02 \mathrm{~m}^{3} / \mathrm{min}\left(248 \mathrm{ft}^{3} / \mathrm{min}\right)(24 \%)$
22.5 to $36.50 \mathrm{~m}^{3} / \mathrm{min}$ (793 to $1,289 \mathrm{ft}^{3} / \mathrm{min}$ )

The location chosen for the measurement is specified in the guidance. 


\subsubsection{Stack 296-A-29; 241-AN Tank Farm Exhaust}

This stack exhausts filtered air from all AN tank exhausts.

STACK SIZE: $25 \mathrm{~cm}(10 \mathrm{in}$.$) diameter, 4.6 \mathrm{~m}(14.9 \mathrm{ft})$ high

FAN DESIGN CAPACITY: Two fans, each rated at $17.0 \mathrm{std} \mathrm{m}^{3} / \mathrm{min}$ at $21^{\circ} \mathrm{C}$ (600 std. $\mathrm{ft}^{3} / \mathrm{min}$ at $70^{\circ} \mathrm{F}$. Only one fan operates at a time. Fan Nos. are K1-5-1 and $\mathrm{K} 1-5-2$.

EMISSION CONTROL DEVICE: Filtration.

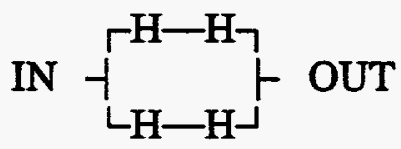

Stack flow rates are measured using Waste Tank Plant Maintenance Procedure 6-TF-155, Air Flow Test for Tank Farm Stacks and Ducts (WHC 1995a).
AVERAGE
$21.7 \mathrm{~m}^{3} / \mathrm{min}\left(765 \mathrm{ft}^{3} / \mathrm{min}\right)$
VARIABILITY
$-13 \% /+8 \%$
STANDARD DEVIATION
$1.5 \mathrm{~m}^{3} / \mathrm{min}\left(53 \mathrm{ft}^{3} / \mathrm{min}\right)$
95\% CONFIDENT INTERVAL $\quad 3.45 \mathrm{~m}^{3} / \mathrm{min}\left(122 \mathrm{ft}^{3} / \mathrm{min}\right)( \pm 16)$
RANGE
18.2 to $25.1 \mathrm{~m}^{3} / \mathrm{min}\left(643\right.$ to $\left.887 \mathrm{ft}^{3} / \mathrm{min}\right)$

The location chosen for the measurement is specified in the guidance.

\subsubsection{Stack 296-A-40; 241-AP Tank Farm Exhaust}

This stack exhausts filtered air from all 241-AP waste storage tanks.

STACK SIZE: $25 \mathrm{~cm}(10 \mathrm{in}$.$) diameter, 4.1 \mathrm{~m}(13.3 \mathrm{ft})$ high

FAN DESIGN CAPACITY: Two fans rated at $33.13 \mathrm{std} . \mathrm{m}^{3} / \mathrm{min}$ at $21^{\circ} \mathrm{C}$ $\left(1,170 \mathrm{std}\right.$. $\mathrm{ft}^{3} / \mathrm{min}$ each at $70^{\circ} \mathrm{F}$. Only one fan runs at a time. Fan Nos. are $\mathrm{K} 1-5-1$ and $\mathrm{K} 1-5-2$.

EMISSION CONTROL DEVICE: Filtration.<smiles></smiles> 
Stack flow rates are measured using Waste Tank Plant Maintenance Procedure 6-TF-155, Air Flow Test for Tank Farm Stacks and Ducts (WHC 1995a).
AVERAGE
VARIABILITY
$27.6 \mathrm{~m}^{3} / \mathrm{min}\left(974 \mathrm{ft}^{3} / \mathrm{min}\right)$
STANDARD DEVIATION
$-27 \% /+21 \%$
95\% CONFIDENT INTERVAL
$4.22 \mathrm{~m}^{3} / \mathrm{min}\left(149 \mathrm{ft}^{3} / \mathrm{min}\right)$
RANGE
$9.54 \mathrm{~m}^{3} / \mathrm{min}\left(337 \mathrm{ft}^{3} / \mathrm{min}\right)( \pm 35 \%)$
18.0 to $37.12 \mathrm{~m}^{3} / \mathrm{min}\left(637\right.$ to $\left.1,311 \mathrm{ft}^{3} / \mathrm{min}\right)$

The location chosen for the measurement is specified in the guidance.

\subsubsection{Stack 296-B-28; 244-BX Salt Well Receiver Exhaust}

This stack exhausts filtered air from the 244-BX tanks and annulus.

STACK SIZE: $15 \mathrm{~cm}(6 \mathrm{in}$.$) diameter 3.4 \mathrm{~m}(11 \mathrm{ft})$ high

FAN DESIGN CAPACITY: $7.08 \mathrm{~m}^{3} / \mathrm{min}\left(250 \mathrm{ft}^{3} / \mathrm{min}\right)$. Designed to vary from 3.54 to $7.08 \mathrm{~m}^{3} / \mathrm{min}$ (125 to $250 \mathrm{ft}^{3} / \mathrm{min}$ ). Fan No. is EF-1.

EMISSION CONTROL DEVICE: Filtration.

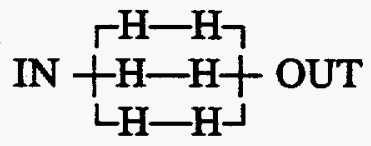

Stack flow rates are measured using Waste Tank Plant Maintenance Procedure 6-TF-155, Air Flow Test for Tank Farm Stacks and Ducts (WHC 1995a).
AVERAGE
$6.63 \mathrm{~m}^{3} / \mathrm{min}\left(234 \mathrm{ft}^{3} / \mathrm{min}\right)$
VARIABILITY
$-18 \% /+12 \%$
STANDARD DEVIATION
$0.65 \mathrm{~m}^{3} / \mathrm{min}\left(23 \mathrm{ft}^{3} / \mathrm{min}\right)$
95\% CONFIDENT INTERVAL
$1.6 \mathrm{~m}^{3} / \mathrm{min}\left(55 \mathrm{ft}^{3} / \mathrm{min}\right)( \pm 24 \%)$
RANGE
5.07 to $8.18 \mathrm{~m}^{3} / \mathrm{min}$ (179 to $\left.289 \mathrm{ft}^{3} / \mathrm{min}\right)$

The location chosen for the measurement is specified in the guidance. 


\subsubsection{Stack 295-C-5; CR Vault Cell and Vessel Ventilation Exhaust}

This stack exhausts filtered air from the 244-CR Vault cell and process ventilation.

STACK SIZE: $46 \mathrm{~cm}$ (18 in.) diameter, $15.2 \mathrm{~m} \mathrm{(50} \mathrm{ft)} \mathrm{high}$

STACK FANS: Two (2) in parallel. One primary, one stand-by. Fan numbers 291-CR-923-1 and -2 .

FAN DESIGN CAPACITY: $119 \mathrm{~m}^{3} / \mathrm{min}\left(4,200 \mathrm{ft}^{3} / \mathrm{min}\right)$ each.

EMISSION CONTROL DEVICE: Filtration.

$$
\mathrm{IN}-4 \mathrm{H}-4 \mathrm{H}-\mathrm{OUT}
$$

Stack flow rates are measured using Waste Tank Plant Maintenance Procedure 6-TF-155, Air Flow Test for Tank Farm Stacks and Ducts (WHC 1995a).
AVERAGE
$72.52 \mathrm{~m}^{3} / \mathrm{min}\left(2,561 \mathrm{ft}^{3} / \mathrm{min}\right)$
VARIABILITY
$-57 \% /+44 \%$
STANDARD DEVIATION
$28.54 \mathrm{~m}^{3} / \mathrm{min}\left(1,008 \mathrm{ft}^{3} / \mathrm{min}\right)$
95\% CONFIDENT INTERVAL
RANGE
$65.78 \mathrm{~m}^{3} / \mathrm{min}\left(2,323 \mathrm{ft}^{3} / \mathrm{min}\right)(91 \%)$
6.71 to $138.3 \mathrm{~m}^{3} / \mathrm{min}\left(237\right.$ to $\left.4,885 \mathrm{ft}^{3} / \mathrm{min}\right)$

The location chosen for the measurement is specified in the guidance.

\subsubsection{Stack 296-P-16; 241-C-105 and 241-C-106 Tank Exhaust}

This stack exhausts filtered air directly from the 241-C-105 and -106 tanks, and indirectly from tank 241-C-104 through cascade line (underground pipe).

STACK SIZE: $41 \mathrm{~cm}(16 \mathrm{in}$.$) diameter, 3.1 \mathrm{~m} \mathrm{(10 \textrm {ft } ) \mathrm { high }}$

FAN DESIGN CAPACITY: $198.2 \mathrm{~m}^{3} / \mathrm{min}$ at $21^{\circ} \mathrm{C}\left(7,000 \mathrm{ft}^{3} / \mathrm{min}\right.$ at $\left.70{ }^{\circ} \mathrm{F}\right)$. No fan number.

EMISSION CONTROL DEVICE: Filtration

$$
\text { IN-9H-9H-OUT }
$$

Stack flow rates are measured using Waste Tank Plant Maintenance Procedure 6-TF-155, Air Flow Test for Tank Farm Stacks and Ducts (WHC 1995a). 
AVERAGE

VARIABILITY

STANDARD DEVIATION

95\% CONFIDENT INTERVAL

RANGE
$91.83 \mathrm{~m}^{3} / \mathrm{min}\left(3,243 \mathrm{ft}^{3} / \mathrm{min}\right)$

$-15 \% /+22 \%$

$9.74 \mathrm{~m}^{3} / \mathrm{min}\left(344 \mathrm{ft}^{3} / \mathrm{min}\right)$

$21.2 \mathrm{~m}^{3} / \mathrm{min}\left(750 \mathrm{ft}^{3} / \mathrm{min}\right)( \pm 23 \%)$

70.59 to $113.1 \mathrm{~m}^{3} / \mathrm{min}\left(2,493\right.$ to $\left.3,993 \mathrm{ft}^{3} / \mathrm{min}\right)$

The location chosen for the measurement is specified in the guidance.

\subsubsection{Stack 296-P-23; 241-SY Tank Farm Exhaust}

This stack exhausts filtered air from the 241-SY-101, -102 , and -103 tank.

STACK SIZE: $20 \mathrm{~cm}(8 \mathrm{in}$.$) diameter, 3.1 \mathrm{~m}(10.2 \mathrm{ft})$ high

FAN DESIGN CAPACITY: $19.8 \mathrm{~m}^{3} / \mathrm{min}$ at $93^{\circ} \mathrm{C}\left(700 \mathrm{ft}^{3} / \mathrm{min}\right.$ at $\left.200^{\circ} \mathrm{F}\right)$. Fan No. is $\mathrm{K} 1-4-1$.

EMISSION CONTROL DEVICE:

$\mathrm{IN}-\mathrm{H}-\mathrm{H}-\mathrm{OUT}$

Stack flow rates are measured using Waste Tank Plant Maintenance Procedure 6-TF-155, Air Flow Test for Tank Farm Stacks and Ducts (WHC 1995a).
AVERAGE
$24.6 \mathrm{~m}^{3} / \mathrm{min}\left(867 \mathrm{ft}^{3} / \mathrm{min}\right)$
VARIABILITY
$-14 \% /+22 \%$
STANDARD DEVIATION
$2.7 \mathrm{~m}^{3} / \mathrm{min}\left(95 \mathrm{ft}^{3} / \mathrm{min}\right)$
95\% CONFIDENT INTERVAL
$5.92 \mathrm{~m}^{3} / \mathrm{min}\left(209 \mathrm{ft}^{3} / \mathrm{min}\right)(24 \%)$
RANGE
18.7 to $30.47 \mathrm{~m}^{3} / \mathrm{min}\left(659\right.$ to $\left.1,076 \mathrm{ft}^{3} / \mathrm{min}\right)$

The location chosen for the measurement is specified in the guidance.

\subsubsection{Stack 296-P-28; 241-SY Backup Tank Farm Exhaust}

This stack currently serves as BACKUP to 296-P-23.

STACK SIZE: $20 \mathrm{~cm}(8 \mathrm{in}$.$) diameter, 3.4 \mathrm{~m}(11 \mathrm{ft})$ high

FAN DESIGN CAPACITY: $28.32 \mathrm{~m}^{3} / \mathrm{min}\left(1,000 \mathrm{ft}^{3} / \mathrm{min}\right)$

EMISSION CONTROL DEVICE: Filtration.

$\mathrm{IN}-\mathrm{H}-\mathrm{H}-\mathrm{OUT}$ 
Stack flow rates are measured using Waste Tank Plant Maintenance Procedure 6-TF-155, Air Flow Test for Tank Farm Stacks and Ducts (WHC 1995a).

AVERAGE
VARIABILITY
STANDARD DEVIATION
95\% CONFIDENT INTERVAL
RANGE

AVERAGE

VARIABILITY 95\% CONFIDENT INTERVAL RANGE

\author{
$20.9 \mathrm{~m}^{3} / \mathrm{min}\left(739 \mathrm{ft}^{3} / \mathrm{min}\right)$ \\ $-18 \% /+14 \%$ \\ $2.5 \mathrm{~m}^{3} / \mathrm{min}\left(88 \mathrm{ft}^{3} / \mathrm{min}\right)$ \\ $6.09 \mathrm{~m}^{3} / \mathrm{min}\left(215 \mathrm{ft}^{3} / \mathrm{min}\right)(29 \%)$ \\ 14.8 to $27.0 \mathrm{~m}^{3} / \mathrm{min}$ (523 to $954 \mathrm{ft}^{3} / \mathrm{min}$ )
}

The location chosen for the measurement is specified in the guidance.

\subsubsection{Stack 296-S-15; 241-SX Tank Farm Exhaust}

This stack exhausts filtered air from tanks 241-SX-101 through -112 and 241-SX-114.

STACK SIZE: $107 \mathrm{~cm}$ (42 in.) diameter, $4.6 \mathrm{~m}(15 \mathrm{ft})$ high

FAN DESIGN CAPACITY: Originally designed to be $321.40 \mathrm{~m}^{3} / \mathrm{min}\left(11,350 \mathrm{ft}^{3} / \mathrm{min}\right)$ each for a total flow of $641.38 \mathrm{~m}^{3} / \mathrm{min}\left(22,650 \mathrm{ft}^{3} / \mathrm{min}\right)$. Later changed to $172.7 \mathrm{~m}^{3} / \mathrm{min}\left(6,100 \mathrm{ft}^{3} / \mathrm{min}\right)$ total flow with one fan used as a backup. Fan Nos. are K1-3-1 N and K1-3-1 S.

EMISSION CONTROL DEVICE: Filtration.<smiles>N#CCOCCO</smiles>

Stack flow rates are measured using Waste Tank Plant Maintenance Procedure 6-TF-155, Air Flow Test for Tank Farm Stacks and Ducts (WHC 1995a).
AVERAGE
$119.3 \mathrm{~m}^{3} / \mathrm{min}\left(4,212 \mathrm{ft}^{3} / \mathrm{min}\right)$
VARIABILITY
$-49 \% /+32 \%$
STANDARD DEVIATION
$29.00 \mathrm{~m}^{3} / \mathrm{min}\left(1,024 \mathrm{ft}^{3} / \mathrm{min}\right)$
95\% CONFIDENT INTERVAL
RANGE
$65.55 \mathrm{~m}^{3} / \mathrm{min}\left(2,315 \mathrm{ft}^{3} / \mathrm{min}\right)(55 \%)$
53.69 to $184.8 \mathrm{~m}^{3} / \mathrm{min}\left(1,896\right.$ to $\left.6,527 \mathrm{ft}^{3} / \mathrm{min}\right)$

The location chosen for the measurement is specified in the guidance. 


\subsubsection{Stack 296-S-22; 244-S Salt Well Receiver Tank and Annulus Exhaust}

This stack exhausts filtered air from the 244-S tank and annulus.

STACK SIZE: $15 \mathrm{~cm}(6 \mathrm{in}$.$) diameter, 3.4 \mathrm{~m}(11 \mathrm{ft})$ high

FAN DESIGN CAPACITY: $4.67 \mathrm{~m}^{3} / \mathrm{min}$ at $116^{\circ} \mathrm{C}\left(165 \mathrm{ft}^{3} / \mathrm{min}\right.$ at $\left.240^{\circ} \mathrm{F}\right)$. Fan No. is $\mathrm{K} 1-5-1$.

EMISSION CONTROL DEVICE: Filtration.

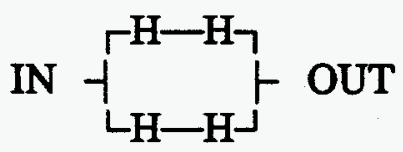

Stack flow rates are measured using Waste Tank Plant Maintenance Procedure 6-TF-155, Air Flow Test for Tank Farm Stacks and Ducts (WHC 1995a).
AVERAGE
VARIABILITY
$4.20 \mathrm{~m}^{3} / \mathrm{min}\left(148 \mathrm{ft}^{3} / \mathrm{min}\right)$
STANDARD DEVIATION
$-18 \% /+18 \%$
95\% CONFIDENT INTERVAL
$1.1 \mathrm{~m}^{3} / \mathrm{min}\left(37 \mathrm{ft}^{3} / \mathrm{min}\right)$
RANGE
$13.2 \mathrm{~m}^{3} / \mathrm{min}\left(467 \mathrm{ft}^{3} / \mathrm{min}\right)$
Not enough data points

The location chosen for the measurement is specified in the guidance.

\subsubsection{Stack 296-T-18; 244-TX Salt Well Receiver Tank and Annulus Exhaust}

This stack exhausts filtered air from the 244-TX tank and annulus.

STACK SIZE: $15 \mathrm{~cm}(6 \mathrm{in}$.$) diameter, 3.4 \mathrm{~m}(11 \mathrm{ft})$ high

FAN DESIGN CAPACITY: $7.09 \mathrm{~m}^{3} / \mathrm{min}\left(250 \mathrm{ft}^{3} / \mathrm{min}\right)$. Stack is designed to vary from 3.54 to $7.09 \mathrm{~m}^{3} / \mathrm{min}$ (125 to $\left.250 \mathrm{ft}^{3} / \mathrm{min}\right)$. Fan No. is EF-1.

EMISSION CONTROL DEVICE: Filtration.<smiles></smiles>

Stack flow rates are measured using Waste Tank Plant Maintenance Procedure 6-TF-155, Air Flow Test for Tank Farm Stacks and Ducts (WHC 1995a). 
AVERAGE

VARIABILITY

STANDARD DEVIATION

95\% CONFIDENT INTERVAL

RANGE
$8.13 \mathrm{~m}^{3} / \mathrm{min}\left(287 \mathrm{ft}^{3} / \mathrm{min}\right)$

$-35 \% /+16 \%$

$1.4 \mathrm{~m}^{3} / \mathrm{min}\left(48 \mathrm{ft}^{3} / \mathrm{min}\right)$

$3.15 \mathrm{~m}^{3} / \mathrm{min}\left(111 \mathrm{ft}^{3} / \mathrm{min}\right)( \pm 39 \%)$

4.96 to $11.3 \mathrm{~m}^{3} / \mathrm{min}\left(175\right.$ to $\left.398 \mathrm{ft}^{3} / \mathrm{min}\right)$

The location chosen for the measurement is specified in the guidance.

\subsubsection{Stack 296-U-11; 244-U Salt Well Receiver Tank and Annulus Exhaust}

This stack exhausts filtered air from the 244-U tank and annulus.

STACK SIZE: $15 \mathrm{~cm}(6 \mathrm{in}$.$) diameter, 4.3 \mathrm{~m}(14 \mathrm{ft})$ high

FAN DESIGN CAPACITY: $7.09 \mathrm{~m}^{3} / \mathrm{min}\left(250 \mathrm{ft}^{3} / \mathrm{min}\right)$.

EMISSION CONTROL DEVICE: Filtration.

$$
\text { IN } \underset{L_{H}-\mathrm{H}_{-}}{\stackrel{\mathrm{H}-\mathrm{H}}{\mathrm{H}}-\mathrm{H}} \text { OUT }
$$

Stack flow rates are measured using Waste Tank Plant Maintenance Procedure 6-TF-155, Air Flow Test for Tank Farm Stacks and Ducts (WHC 1995a).

Historical stack flowrate data is not available; however, the stack flowrate should be similar to the 244-BX and 244-TX stacks because they are similar in design.

The location chosen for the measurement is specified in the guidance.

\subsection{LIQUID EFFLUENTS}

Liquid effluents include:

- 244AR Vault Cooling Water (CAR) to 216-B-3C Pond. The source of this stream is the cooling water and/or steam condensate from process and vessel ventilation system condensates, and other miscellaneous sources.

- 241-A Tank Farm Surface Condenser Cooling Water (CAR) to 216-B-3 Pond. Cooling water from the surface condensers for 241-AY and -AZ Tank Farms is collected in this waste stream. 


\subsection{EFFLUENT MONITORING/SAMPLING SYSTEM DESIGN CRITERIA}

\subsection{EFFLUENT MONITORING SYSTEM GENERAL DESIGN CRITERIA}

The design criteria for the stack monitoring and sampling systems is specified in WHC-SD-EN-TI-288, Rev. 0, Functional Requirements Document for Measuring Emissions of Airborne Radioactive Materials (WHC 1994f).

\subsection{EFFLUENT MONITORING SYSTEM REQUIREMENTS/CONSIDERATIONS}

The NESHAP establishes requirements and procedures for measuring radionuclide emissions from point sources (e.g., stacks and vents). The requirements and procedures are contained in 40 CFR 61.93. Alternative procedures are allowed if EPA has granted prior approval. The following sections present methods that the NESHAP mandates for an airborne radionuclide effluent monitoring system. Alternative methods are allowed but they must have received prior EPA approval.

The NESHAP in 40 CFR Part 61 specifies parameters that must be sampled or measured and specific implementation methods. The methods are contained in 40 CFR 60, Appendix A and 40 CFR 61, Appendix B. The following six elements are the essential requirements for design and operation of an airborne effluent release monitoring system mandated by the NESHAP for DOE facilities.

- Effluent flow rate must be measured using EPA Method 2 in large stacks and vents or EPA Method 2A in pipes and small vents.

- Radionuclides shall be directly monitored or extracted, collected and measured.

- The placement of the sampling/monitoring probe or sensor must be derived using EPA Method 1.

- If measurement is not performed in situ, the guidance presented in ANSI N13.1 1969 must be followed for sample extraction.

- Radionuclides must be measured according to 40 CFR 61, Appendix B, Method 114.

- A quality assurance program must be conducted that meets the performance requirements described in 40 CFR 61, Appendix B, Method 114.

The following sections present these requirements in more detail and discuss their importance. 


\subsubsection{Measurement of Effluent Flow Rate}

The NESHAP requires that flow rate measurements be made. The flow rate (volumetric) needs to be accurately quantified so that concentrations or activity levels, measured in the samples that are extracted, can be used to derive total emission rates. The volumetric flow rate is the product of the cross-sectional area of the stack and the effluent velocity. The measurement of velocity is complicated by its variation across the diameter of the stack. For stacks with a circular cross-section, the maximum velocity occurs at the center of the stack and the velocity approaches zero at the stack wall.

The NESHAP specifies EPA Reference Method 2 to determine velocity and volumetric flow rate for stacks and large vents. Reference Method 2A is specified for flow rates through pipes and small vents. Both methods are contained in 40 CFR 60, Appendix A.

Method 2 specifies the measurement of average gas velocity with a Type $S$ pitot tube. It is applicable to any gas stream where a measurement site that meet the criteria of Method 1 is available. It cannot be used in cyclonic or swirling gas streams.

Method 2A specifies the measurement of average gas velocity directly with a gas volume meter. Temperature and pressure measurements are made to correct the volume to standard conditions. It is applicable to pipes and small ducts, either in-line or at exhaust positions, within the temperature range of $0{ }^{\circ} \mathrm{C}$ to $50^{\circ} \mathrm{C}\left(32^{\circ} \mathrm{F}\right.$ to $\left.122^{\circ} \mathrm{F}\right)$.

The NESHAP does not define a specific frequency for conducting flow rate measurements. The rule states that the frequency of flow rate measurements should be dependent upon the variability of the effluent flow rate. If the flow is highly variable, continuous or frequent flow rate measurements must be made. For consistent flow rates, only periodic measurements are necessary.

\subsubsection{Measurement of Radionuclides}

The NESHAP mandates that radionuclides be monitored in situ or extracted, collected, and measured. The effluent stream must be monitored continuously with an in-line (in situ) detector, or representative samples must be extracted continuously. Periodic sampling may be used only with EPA's prior approval, and the frequency must be sufficient to provide representative sampling.

The NESHAP requires that radionuclides be measured at the point of release so that dispersion modeling can then be used to estimate the ambient impact (dose) at critical receptors. Measurements are made on samples of the effluent. The samples must be representative of the entire effluent stream to minimize over- or underestimation of the characteristics of the effluent and the estimated ambient impacts. The characteristics of the effluent stream can vary temporally and spatially. The procedures specified by the NESHAP are designed to ensure that samples are representative. 40 CFR 61.93(b)(2)(ii) mandates that 
monitoring or sample extraction be performed continuously. This eliminates or at least mitigates the impact of temporal variation on the representativeness of the sample. The NESHAP also mitigates the impact of spatial variation on representativeness of the sample by mandating a method for identifying an acceptable sampling site. This method is presented in the next section.

\subsubsection{Sampling or Monitoring Site Location (EPA Method 1)}

In order to obtain a representative sample that considers the impact of spatial variation the NESHAP [40 CFR 61.93(b)(2)(i)] mandates that EPA Method 1 be employed to select a monitoring or sampling site. EPA Method 1 can be found in 40 CFR 60, Appendix A. The purpose of the method is to aid in the representative measurement of contaminants and volumetric flow rate by identifying a measurement site where the effluent stream is flowing in a known direction. The method also divides the stack into cross-sections of equal areas. The method is applicable to flowing gas streams in ducts, stacks or vents. It cannot be used when (1) flow is cyclonic or swirling, (2) a stack is smaller than 12 in. in diameter, or (3) the measurement site is less than two stack diameters downstream or less than a half diameter upstream from a flow disturbance.

\subsubsection{Sample Extraction (ANSI N13.1 1969)}

If the sample must be extracted from the effluent stream and transported to a collection device or analyzer, precautions must be taken to ensure that the representativeness of the sample is not affected by the extraction process.

If it is necessary to extract the sample from the effluent for collection or measurement, the NESHAP [40 CFR 61.93(b)(2)(i)] mandates that ANSI N13.1 (ANSI 1969) be followed to mitigate changes in the characteristics of the sample due to extraction and transport of the sample to the collection or measurement device.

ANSI N13.1 1969, Guide to Sampling Airborne Radioactive Materials in Nuclear Facilities, provides the guideline for design of an effluent monitoring system. The standard encompasses the design of the probe and the transport system for moving the sample from the probe's orifice to the sample collection device or analyzer.

The guidelines in ANSI N13.1 are designed to ensure that the sample that is collected and/or measured represents the effluent slip stream at the point of extraction. Factors that affect the representativeness of the sample during collection and transport are inertial separation, deposition, impaction, sample loss/dilution, physical changes, and/or chemical activity. ANSI N13.1 provides guidance for mitigating the impact of each of these factors. 
6.2.4.1 Inertial Separation. Radioactive particulate matter is frequently a contaminant of concern in airborne effluents. Particulate matter consists of small solid and liquid particles. These particles when entrained in an airstream tend to continue to move in a straight line, due to momentum, when the air stream flow is redirected due to a bend, tee, change in diameter, or other flow disturbance. The greater the mass of the particle, the greater the tendency to continue to move in a straight line. This is the principal mechanism of inertial separation. It is employed in cyclonic separators to remove particles from an effluent stream, or at the inlet of an air sampling device to obtain a sample that is differentiated by size. The location of a sample probe should avoid regions where a change in the direction of the airstream flow may result in an unrepresentative particle size distribution.

ANSI N13.1 recommends that a sampling point should be a minimum of five diameters (or five times the major dimension for rectangular ducts) downstream from abrupt changes in flow direction or prominent transitions. However, the NESHAP requires that Method 1 be used to select sampling sides. Method 1 requires that the probe is eight diameters upstream and two diameters downstream from a flow disturbance. The more restrictive requirements of Method 1 should be applied.

Inertial separation can be induced in particles entrained in an airstream by suddenly changing the velocity of the airstream. In airborne effluent monitoring systems, distortion in particle size distributions may occur when the velocity of the sampled air entering the sample probe (or collector, when supported directly in the stream to be sampled) is significantly different from the velocity of the air in the stream sampled. When the air drawn through the sampler or collector in the stream is at a much lower velocity than the stream velocity, larger particles will be preferentially collected. When the air velocity through the sample probe and collector is greater than the stream velocity smaller particles will be preferentially collected. The degree to which the fractionation occurs is a function of particle size, density, the particle size distribution, and the difference between the isokinetic velocity and the an isokinetic velocity employed. Except in very unusual situations, particles smaller than an aerodynamic diameter of about five microns are able to follow the streamlines of the air, and the fractionation error is not great.

ANSI N13.1 recommends that in applications in which particle sizes may be expected to vary, particularly when particles larger than five microns are anticipated, the sampler arrangement be designed to permit near isokinetic flow into the sampler entry probe or through the collector when the collector is facing into the stream sampled.

6.2.4.2 Deposition Losses. The principal mechanisms by which particles are deposited are gravity settling and Brownian diffusion when the flow is laminar. Particles carried by an airstream moving in a horizontal tube will tend to settle to the bottom of the tube due to the influence of gravity. Any delivery line through which the sample is carried to the collection or measurement device will preferentially remove large particles through gravitational settling when the flow is too low. Very small particles can diffuse to the wall of a conduit by Brownian motion. Particle size is of extreme significance. Very small particles are lost to the wall rapidly when gas flow is very low. 
ANSI N13.1, Appendix B recommends that sampling lines be avoided whenever possible and always kept at a minimum length. In every case where sampling delivery lines are required, an evaluation should be made of deposition in the lines. Appendix B also provides a table that allows a determination to be made of the significance of distortion due to deposition.

6.2.4.3 Impaction Losses. Particles carried in turbulent flow will be deposited on the walls of a conduit due to the adhesive properties of the particle and the wall. The degree of deposition depends upon particle size and density, the average velocity of the air, and the diameter and length of the conduit. Deposition does not continue to increase indefinitely as the velocity and particle size increases. A velocity will be reached above which particles will be re-entrained. The onset of re-entrainment is a function of particle size, the particle density, tube diameter, and the adhesive properties of the particle and wall.

6.2.4.4 Physical Changes. A change in the physical state (e.g., liquid, gas, solid) of an airstream constituent can result in sample distortions. Such changes can be precipitated by a temperature and/or pressure change. Moisture in the sample can result in condensate on the inner surfaces of sampling lines that may form pockets and act as traps, or provide wetted surfaces to which the contaminant of interest may adhere. In extreme situations traps and pockets may act as effective scrubbers for the radioactive material transported. Excessive moisture may also destroy filter media usefulness either by blocking the air passageways through the pores, or by weakening it to a point that it tears or breaks easily. ANSI N13.1 recommends heated sampling lines when heavy moisture loadings are anticipated, to prevent condensation in the lines and to raise the collector temperature well above dewpoint.

6.2.4.5 Chemical Activity. Chemically reactive contaminants in the extracted sample can be largely absorbed on or react with materials of construction resulting in under-representation in the analysis. In addition the corrosion, clogging, and uneven surfaces that can result from chemically active constituents can result in distortion of the measurement of non-reactive contaminants. ANSI N13.1 recommends extreme care when extracting a sample from an airstream when the air contains chemically reactive forms of radioactive isotopes. Precautions would include having a thorough understanding of the chemical composition of the airstream and the materials of construction of the effluent monitoring/sampling system. For example, when radioiodine is a constituent, materials to be avoided in sampling systems are rubber, copper, and some plastics.

6.2.4.6 Sample Loss/Dilution. There are many mechanisms that can result in sample loss. An isokinetic sample extraction can cause the loss of larger or smaller particles. Deposition or impaction in sample transport lines can cause losses of particulate matter. Chemical reaction of the sample with the material of construction can cause sample loss due to absorption or it can become fixed because it reacted with a system component. The reactions can also cause physical obstructions that interfere with the transfer of nonreactive contaminants resulting in losses at the collection or measurement device. 
Since sample transfer lines operate at below atmospheric pressure, system leaks will generally introduce ambient air into the sampling lines that will dilute the constituents in the sample.

ANSI N13.1 recommends that sampling lines be avoided whenever possible and always kept at a minimum length. Guidelines to mitigate the various types of line losses were presented in the previous five sections. In addition, good operating practice would mandate identification of effluent monitoring system leakage and expedient corrective action to preclude sample dilution from this type of problem.

\subsubsection{Sample Analysis (EPA Method 114)}

The requirements for determining the amounts of radionuclides collected by the effluent sampling system are provided in EPA Method 114, which is codified in 40 CFR 61, Appendix B. The appropriate sample analysis for a radionuclide is dependent upon a number of interrelated factors including the mixture of other radionuclides present. Therefore, a series of methods based on "principles of measurement" are described for monitoring and sample collection and analysis; these methods are applicable to the measurement of radionuclides found in effluent streams at stationary sources. The approach provides flexibility to choose the most appropriate combination of monitoring and sample collection and analysis methods.

6.2.5.1 Stack Monitoring and Sample Collection Methods. EPA Method 114 presents monitoring and sample collection methods based on "principles of monitoring and sample collection" which are applicable to the measurement of radionuclides from effluent streams at stationary sources. The collection media (i.e., filters) for particulate radionuclides are incorporated by reference to ANSI N13.1. Collection methods for other radionuclide physical states are listed in EPA Method 114.

6.2.5.2 Radionuclide Analysis Methods. EPA Method 114 presents a series of methods based on "principles of measurement," which are applicable to the analysis of radionuclides collected from airborne effluent streams at stationary sources. These methods are applicable only under the conditions stated and within the limitations described. Some methods specify that only a single radionuclide be present in the sample or the chemically separated sample. This condition should be interpreted to mean that no other radionuclides are present in quantities that would interfere with the measurement. The methods that are applicable are dependent upon the type of radiation emitted.

\subsubsection{Quality Assurance Program for Effluent Monitoring}

EPA Method 114 presents minimum requirements for QA program. The QA program must be documented in a project plan that addresses all the QA elements prescribed in Method 114. The QA Project Plan is documented in WHC-EP-0446-2 (WHC 1994b). 


\title{
6.3 ACCEPTANCE TEST PROCEDURE
}

A generic Acceptance Test Procedure (ATP-G-999-00010 [WHC 1981]) is used at the Hanford Site to verify initial stack sampling system operability. This procedure provides electrical, mechanical, and alarm function checks as identified in RHO-MA-241, "Installation Criteria for the Generic Airborne Radioactive Contamination Sampling and Monitoring System" (RHO 1980b). Applicable sections of this acceptance test procedure are applied to facility-specific airborne effluent monitoring/sampling systems.

\subsection{CONTINUOUS AIR MONITOR (CAM)}

The following is a list of CAMs approved for use at Hanford by Radiological Control Technology Group.

\author{
ALPHA CAMS \\ Eberline 3 \\ Eberline 4 \\ Eberline 5 \\ Eberline 5A \\ Eberline 5AS \\ BETA/GAMMA CAMS \\ Eberline AMS-3 \\ Eberline AMS-3A \\ Eberline AMS-3A-1
}


WHC-EP-0479-1

This page intentionally left blank. 


\subsection{CHARACTERIZATION OF CURRENT EFFLUENT MONITORING SYSTEM}

\subsection{GENERIC STACK SAMPLING/MONITORING INSTRUMENTATION}

Most of the stack sampling/monitoring systems in the stacks discussed in this FEMP are of generic design. Section 7.3 gives specific instrumentation in each system. The stack sampling and monitoring systems consist of continuous air monitors (CAMs) and record samplers. The discussion presented here, however, centers mostly on the record samplers. CAM alarms are discussed in Section 7.2. The entire stack radionuclide sampling system consists of the following elements:

- The sampling probe withdraws the sample from the stack.

- The sample transport line transports the sample to a sample collection (record sampler) and/or other detection devices (CAMs).

- Heat trace on the sample transport line to prevent condensation.

- The collection and/or detection devices collect the sample.

- The rotameter measures the flow through the system.

- The gasmeter or totalizer totals the sample flow.

- The pressure or vacuum gauge measures the vacuum in the system.

- The flow switch indicates when the sample flow falls below established limits.

- The flow regulator is used to adjust the flow to maintain established flow rates through the sampling system.

- The vacuum pump supplies the flow through the system.

- The timer indicates the length of time the collection devices have been operating.

The sampling system elements and associated measurement errors are discussed in greater detail in the WHC-SD-WM-ES-291-1 (WHC 1994e). A brief description is provided in the following sections. 


\subsubsection{Stack Sampling Probe}

The sampling probe withdraws a sample from the stack or stream of interest. Most of the 200 Area Tank Farm radionuclide sampling systems are designed to sample isokinetically (i.e., sample probe intake velocity $=$ stack velocity) by sizing the stack's sampling probes to a design sample flow rate and stack flow rate.

At some facilities, the sampling systems are designed with a single sampling probe. In these cases, the sample from the probe is split and routed to the record sampler and to the CAM(s). At other facilities, multiple sampling probes are used, one for the record sampler and one for the CAM(s).

Most of the 200 area Tank Farm record sampling systems are designed to operate at a $6 \mathrm{E}-2 \mathrm{~m}^{3} / \mathrm{min}\left(2.2 \mathrm{ft}^{3} / \mathrm{min}\right)$ sample flow rate (reflected on the probe design paperwork for the various stacks). A lower flow rate of $6 \mathrm{E}-2 \mathrm{~m} \mathrm{~m}^{3} / \mathrm{min}\left(2.0 \mathrm{ft}^{3} / \mathrm{min}\right)$ is allowed for the CAMs; however, the design is still based on $6 \mathrm{E}-2 \mathrm{~m}^{3} / \mathrm{min}\left(2.2 \mathrm{ft}^{3} / \mathrm{min}\right)$. The lower flow rate $6 \mathrm{E}-2 \mathrm{~m}^{3} / \mathrm{min}\left(2 \mathrm{ft}^{3} / \mathrm{min}\right)$ theoretically results in the CAMs oversampling (with respect to large particles) the airborne effluent stream. Because the ratio of the sample nozzle velocity to the stack velocity is the determining factor in the degree of oversampling, the exact amount of oversampling can only be determined upon close examination of each system. Because CAMs are monitoring devices which provide notification of increasing particulate radionuclide emissions, this oversampling improves the sampling system collection efficiency.

\subsubsection{Record Sample Collection Filter Paper and Holder}

The record sample collection filter paper and holder collects/samples particulate radionuclides from the stack or stream. This filter is sent to the laboratory on a periodic basis for analysis. The analytical results are used to quantify radionuclide emissions.

The record sample collection filter paper is held inside a holder. This holder requires inspection periodically for wear and for leaks. The filter paper needs to be removed for laboratory analysis and replaced with a new filter on a predetermined schedule. The filter used in the filter holder is a Gelman Sciences Versapor 3000 - Supported Membrane type. The manufacturer specifies that this filter has a $91 \%$ collection efficiency for 0.3 micron particles (Butcher 1991).

A new filter has recently become available. It is a $3000 \mathrm{H}$ hydroploblis filter. This new filter performs better than the 3000 model.

Most of the sampling systems consist of both record samplers and CAMs. The record sample portion of the sampling system is considered the regulatory portion of the system used to quantify and report what dose the public receives from operation of that particular emission point. The CAMs are considered safety devices and are set to alarm if emissions 
concentrations increase above preset levels. The CAMs can also be used as backup regulatory devices. The difference between the CAMs and the record samplers is a detector above or near the collection filter paper in the CAM. The record samplers only contain filter paper. If the filter paper from the record sampler could not be used for analysis for some reason, the CAM's filter paper may be used as a backup.

\subsubsection{Rotameter}

The rotameter measures the flow rate through the sampling system. Knowing the flow rate is important to acquire a good sample. The rotameter consists of a ball floating in a column of fluid (air) in a tube. The model primarily used at Tank Farms is a DWYER/RMC-103PF. No calibration is required for this instrument. This model has neither flow adjustment nor calibration scale adjustment.

\subsubsection{Gasmeter}

The gasmeter or totalizer quantifies the flow through the sampling system. This totalizer complies with specifications which state that a meter must remain within $\pm 2.0 \%$ accuracy at $28,000 \mathrm{~m}^{3}\left(1,000,000 \mathrm{ft}^{3}\right)$ total volume. This is basically the same system used on homes across the country. The manufacturer-supplied data shows that this meter is well within the required accuracy (regulations specify the accuracy to be within $2 \%$ ). In fact, the data supplied showed this meter to be accurate to $-0.4 \%$ at the maximum designed full rate and to $+0.2 \%$ accurate at $20 \%$ of the maximum designed full flow rate for an average volume of $28,000 \mathrm{~m}^{3}\left(1,000,000 \mathrm{ft}^{3}\right)$.

\subsubsection{Vacuum Gauge}

The pressure (or vacuum) gauge measures the vacuum in the sampling system. The air coming from the stacks is first run through the record sample filter paper, then the flow meter and totalizer, and finally the air pump which pulls the air through the system. The more particulate matter collected by sample filter paper the higher the vacuum in the system. The filter papers are generally replaced on a weekly basis. Over this week, the vacuum within the sampling system should theoretically increase as particulate matter is collected. The pressure gauge readings are used in emission calculations to acquire the true flow rate (from the rotameter recorded reading) and/or totalized flow (from the gasmeter recorded reading). 


\subsubsection{Flow Switch}

The flow switch indicates when the sample flow falls below established limits. The purpose is three fold:

a. to prevent damage to the sample collection filter paper. As the filter paper collects particulates, the vacuum increases and the sample flow rate drops. If the vacuum increases too much the filter paper may be damaged.

b. to prevent nonrepresentative sampling due to anisokinetic sampling conditions. As the flow drops, isokinetic conditions necessary to acquire a representative sample are not maintained.

c. to indicate vacuum pump problems (e.g. no flow or failed condition).

\subsubsection{Flow Regulator}

The flow regulator adjusts to maintain an established flow within the system. Calibration is not required. This regulator is an EBERLINE 10552-CO2 RAP-1.

\subsubsection{Vacuum Pump and Filters}

The vacuum pump inlet filter provides filtered air to the pump. This filter should be replaced periodically. The pump is a constant flow device. It does not need calibration. The pump is a GAST MODEL NO. 0822-V103-G271X. The Pump is an oil-less carbon vane rotary pump with inlet and outlet filter/manifold assemblies. It is a 373 watts (1/2 HP), $115 / 230 \mathrm{VAC}, 60 \mathrm{~Hz}$, single phase motor.

\subsubsection{Timer}

The timer indicates the length of time the filter paper has been collecting a sample. This information is necessary for emission calculations. Most of the stack record sampling systems contain a switched and an unswitched power receptacle. Power is lost to the switched receptacle when the exhauster fan is turned off. The record sampling system, along with the timer are designed to be plugged into the switched receptacle. In this way, this timer will indicate the length of time the exhauster has been running as well. This is important because the sampling system should only be sampling when the exhauster is on. This timer is a CRAMER 10083. The timer readout is an elapsed time resettable 5 digit meter which reads in hours. The first digit reads in tens of an hour. It has a specified certified accuracy to $\pm 1 \%$. The manufacturer says that there is no adjustment on this timer, therefore no calibration can be accomplished. 
This device is a synchronous motor; the accuracy of the timer is a function of the accuracy of our line frequency. Discussions with the electrical people indicate that 58.5 to $61.5 \mathrm{hz}$ is run; which means the real accuracy of the timer is on the order of $+/-2.5 \%$. However, the timer only indicates hours and tenths, and if it is assumed that one could accurately read one-half the smallest graduation, then the timer is only capable of accurately indicating $+/-5 \%$. It is recommended that the timer be replaced on an annual basis in lieu of wasting time and money checking this device.

\subsubsection{Instrument Enclosure}

The standard design for the tank ventilation systems consists of a record sampler and a beta-gamma CAM that are installed in a weather-resistant cabinet. Figure 7-1 represents a composite generic monitor/sampler instrument enclosure and shows the equipment and instrumentation that can be located in one of the enclosures. Two thermostats control the cabinet environment. When the temperature in the cabinet drops below $18 \pm 3{ }^{\circ} \mathrm{C}$ $\left(65^{\circ} \mathrm{F} \pm 5^{\circ} \mathrm{F}\right)$, the cabinet heater is activated and operates until the temperature reaches $24 \pm 3{ }^{\circ} \mathrm{C}\left(75^{\circ} \mathrm{F} \pm 5^{\circ} \mathrm{F}\right)$. The lower setting for the thermostat that controls the heater is above $10^{\circ} \mathrm{C}\left(50^{\circ} \mathrm{F}\right)$, limiting the potential for moisture condensation (RHO 1980a). A second thermostat actuates a fan to prevent the cabinet temperature from increasing to above $52^{\circ} \mathrm{C}\left(125^{\circ} \mathrm{F}\right)$, the upper limit for proper Beta/Gamma CAM operation.

Summer temperatures greater than $35 \pm 3{ }^{\circ} \mathrm{C}\left(95^{\circ} \mathrm{F} \pm 5^{\circ} \mathrm{F}\right)$ activate a ventilation fan, which draws in air from the outside to remove heat from the cabinet. An alarm light mounted on the cabinet alarm panel is activated if the temperature falls below $13^{\circ} \mathrm{C}\left(55^{\circ} \mathrm{F}\right)$ or exceeds $52^{\circ} \mathrm{C}\left(125^{\circ} \mathrm{F}\right)$.

The instrument enclosure has a rotating beacon in a plastic dome and a bell that are actuated by off-normal conditions. On all of the standard enclosures, the beacon alarm light is actuated by high or low temperatures in the enclosure, beta-gamma CAM (and/or Alpha CAM) failure, or low sample flow through the record sampler. If the beta-gamma CAM (or Alpha CAM) detects a level of radioactivity exceeding the alarm set point, the beacon and the bell on the side of the enclosure are activated.

\subsection{ALARM SET POINTS}

The quantity of material released from a stack effluent stream is of primary importance in emission reporting. For radionuclides, these quantities are normally reported in units of curies (abbreviated as $\mathrm{Ci}$ ). From these quantities, offsite dose consequences are calculated. Regulatory limits are normally in terms of offsite dose limits. Not only are the regulations concerned with the quantity emitted, they are also interested in an increase in emissions. CAMs can be used to indicate an increase in emissions. Since this is the case, it is logical 
Figure 7-1. Composite Generic Monitor/Sampler Instrument Enclosure.

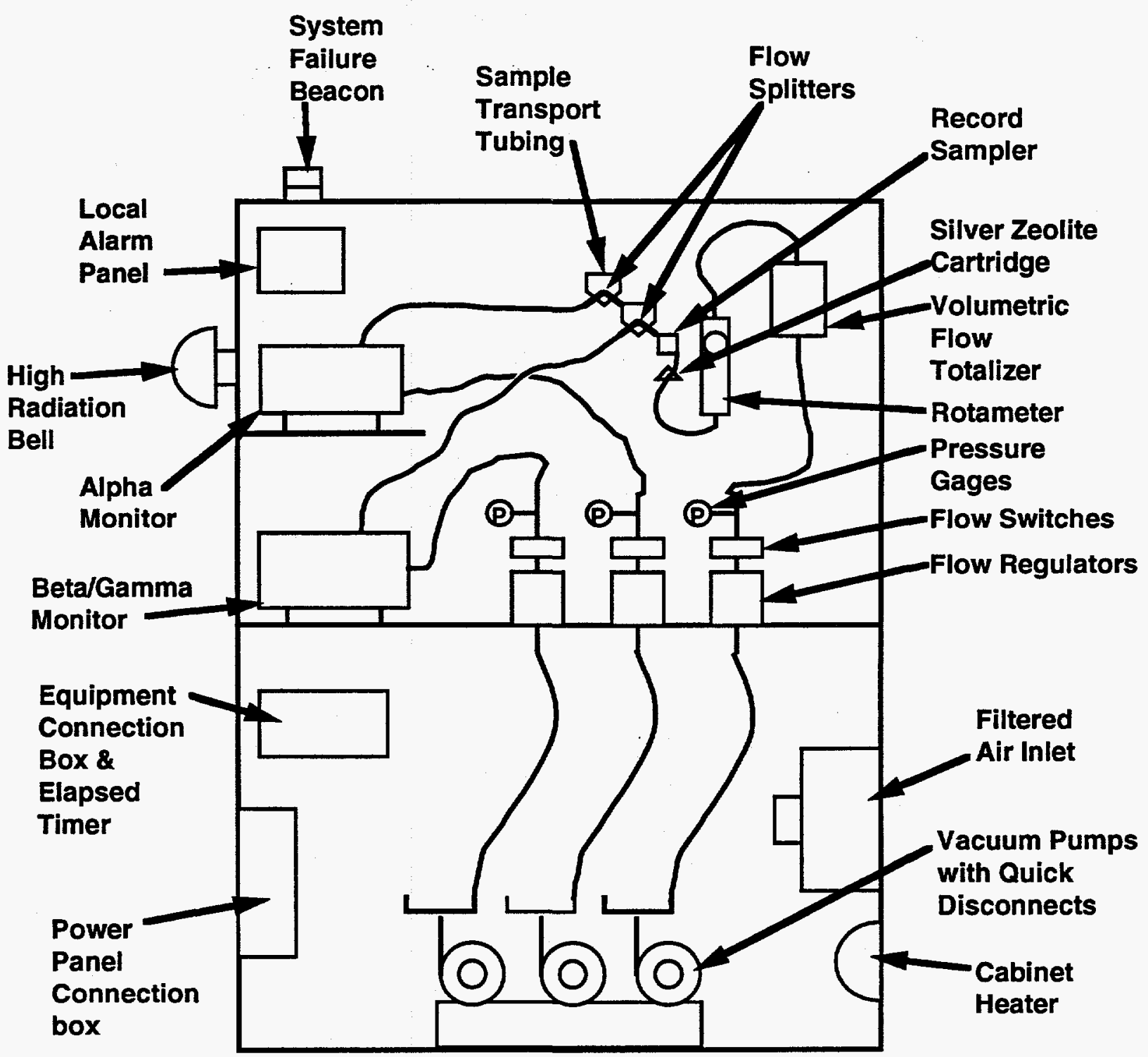

29110019.1 
to assume that the alarm set point should be based on a value just above historical emissions plus background. The Environmental Compliance Manual, WHC-CM-7-5, Section 2.0, "Air Quality," discusses alarm set points as follows:

"Monitoring systems shall alarm at emission concentrations as low as possible without resulting in an excessive number of alarms due to normal fluctuations in background or normal fluctuations in emissions. The alarms are intended to provide timely warnings when the radionuclide concentration or content of emissions has increased significantly so that corrective actions are required to prevent their exceeding the discharge limits. The alarm settings for a specific facility may be selected by the cognizant engineer of the facility who has detailed knowledge of both its process design and its operating experience."

WHC-CM-7-5, Section 2.0 also states:

"Monitoring systems shall, as a minimum, have the capability to alarm at less than or equal to the time-integrated equivalent concentration equal to a 4-hour release at 5,000 times the DCG-public value, as noted in Appendix C of this manual."

Though WHC-CM-7-5 Manual is used for environmental compliance purposes, the alarm set points are actually established and set by the field Health Physics Technicians (HPTs) via the methods established in WHC-IP-0718 (Appendix I), Section 4.2, Continuous Air Monitoring (WHC 1994a). What this document has to say about alarm set points is:

"Alarm set points for environmental release points are determined by Radiological Engineering."

"Continuous air monitors should be capable of measuring 1 derived air concentration (DAC) when averaged over 8 hours (8 DAC-hours) under laboratory conditions."

"Because of ALARA: The CAM alarm set points (ASP) shall be set at the lowest practical level possible to indicate loss of containment or the need for corrective action without resulting in a significant number of false alarms (i.e., false alarms should not exceed one per month)."

What is given in these two documents, though contradictory on responsibilities for establishing alarm settings and use of concentration values (DAC vs DCG - defined next), actually do lead to the same results - setting the alarm to the lowest practical level. The DAC and the DCG are defined as follows:

DERIVED AIR CONCENTRATION (DAC): The concentration of a radionuclide in air that, if inhaled over a period of a work year, would result in a dose equal to the ALI. The DAC is obtained by dividing the ALI by the dose received per curie of 
radionuclide inhaled/ingested, then by the volume of air inhaled by an average worker during a working year $2400 \mathrm{~m}^{3}\left(85,000 \mathrm{ft}^{3}\right)$. DACs are listed in 10 CFR 20, Appendix B.

ANNUAL LIMTT ON INTAKE (ALI): The quantity of a single radionuclide which, if inhaled or ingested for 1 work-year, would result in a committed effective dose equivalent (represented by reference man as defined in Publication 23 of the International Commission on Radiological Protection [ICRP 1979]) of 5 REM. In DOE 5480.11 (DOE 1988a), DACs are used for controlling exposures.

DERIVED CONCENTRATION GUIDES (DCG): The DCG values are listed WHC-CM-7-5, Appendix C. DCGs were derived for the purpose of relating concentrations of radionuclides in the environment to a human dose. The DCG values relate to a 100 mrem dose only when applied at the point of exposure to humans. When a standard person is exposed continuously for 1 year to air concentrations at one times the DCG values, they will receive an effective committed dose equivalent of 100 mrem. When more than one radionuclide is involved in the exposure, the fractional relationship of the concentration of each radionuclide to its respective DCG value must be summed to determine the total dose from the radionuclide mix.

With that said, the rest of this discussion is devoted to examination of how the alarm set point is established, recommendation of what the alarm set points should be, and to explain what the alarm set point really means.

\subsubsection{Emissions Limits}

WHC-CM-7-5 establishes emissions limits as follows:

The annual average concentration of radionuclides released to the environment shall not exceed an Administrative Control Value (ACV) of 1 times the DCG-public value (unity rule applies) at the point of emission (the exit of the stack).

The weekly average (any consecutive 7-day period) concentration of radionuclides released to the environment in airborne emissions should not exceed 10 times the annual average ACV concentration specified for that stack at the point of emission. 
Emission limits for each specific applicable stack are specified in appropriate Operational Specification Documents (OSDs) as:

OSD-T-151-00007, Rev. H-10, Operating Specifications For 241, AN, AP, AW, AY, $A Z$, \& SY Tank Farms (WHC 1995b) includes:

\begin{tabular}{ll} 
Stack Number & \multicolumn{1}{c}{ Facility } \\
296-A-27 & 241-AW Tank Farm Exhauster \\
$296-A-29$ & 241-AN Tank Farm Exhauster \\
$296-A-40$ & 241-AP Tank Farm Exhauster \\
$296-P-23$ & 241-SY Tank Farm Exhauster \\
$296-P-28$ & 241-SY Tank Farm Backup Exhauster
\end{tabular}

Specified Emission Limits are:

Annual average concentrations not to exceed 1 times the DCG

Exceptions: not to exceed 10 times the DCG for:

$296-A-17$
$296-A-27$
$296-A-29$

Weekly average concentrations not to exceed 10 times the DCG

Instantaneous concentrations not to exceed 5000 times the DCG averaged over 4 hours.

OSD-T-151-00011, Rev. C-1, Operating Specifications For SaltWell Receiver Vessels (Joncus 1990) includes:

Stack Number $\quad$ Facility
296-A-25
244-A Double Contained Receiver Tank Exhauster
296-B-28 244-BX Double Contained Receiver Tank Exhauster
296-S-22
244-S Double Contained Receiver Tank Exhauster
296-T-18
244-TX Double Contained Receiver Tank Exhauster
296-U-11
244-U Double Contained Receiver Tank Exhauster 
Specified Emission Limits are:

Annual average concentrations not to exceed 1 times the DCG

Two week average concentrations not to exceed 4 times the DCG

Instantaneous concentrations not to exceed 5000 times the DCG.

OSD-T-151-00013, Rev. D-4, Operating Specifications For Single-Shell Waste Storage Tanks (WHC 1994L) includes:

Stack Number $\quad$ Facility

296-P-16 241-C-105/106 Tank Exhauster

296-S-15 241-SX Tank Farm Exhauster

Specified Emission Limits are:

Annual average concentrations not to exceed 1 times the DCG

Two week average concentrations not to exceed 4 times the DCG

Instantaneous concentrations not to exceed 5000 times the DCG.

OSD-T-151-00015, Rev. B-6, Operating Specifications For Miscellaneous Facilities (WHC 1995c) includes:

Stack Number $\quad \underline{\text { Facility }}$

296-C-05 244-CR Vault Exhauster

Specified Emission Limits are:

Annual average concentrations not to exceed 1 times the DCG

Two week average concentrations not to exceed 4 times the DCG

Instantaneous concentrations not to exceed 5000 times the DCG averaged over 4 hours. 
OSD-T-151-00016, Rev. C-2, Operating Specifications For the 241-A-702 Vessel Ventilation System (WHC 1994j) includes:

Stack Number

Facility

$$
\text { 296-A-17 }
$$

296-P-26

241-AY/AZ Tank Farms Exhauster

241-AY/AZ Tank Farms Backup Exhauster (4000 $\left.\mathrm{ft}^{3} / \mathrm{min}\right)$

Specified Emission Limits are:

Annual average concentrations not to exceed 10 times the DCG

Instantaneous concentrations not to exceed 40 times the DCG averaged over 4 hours.

\subsubsection{Alarm Set Point Derivation}

The amount of material that is released from a stack effluent stream can be determined by multiplying the concentration of that material in the effluent stream by the total volume of the effluent stream that was released. This can be expressed mathematically as follows:

$$
\operatorname{Tr}=\rho_{\mathrm{k}} * \mathrm{~V}_{\mathrm{k}}
$$

where:

$\operatorname{Tr}$ is the total amount released

$\rho_{\mathbf{x}}$ is the concentration of the material in the effluent stream

$V_{k}$ is the released volume of the effluent stream

Table 7-1 summarizes these limits. 
Table 7-1. Emission Limits. (2 sheets)

\begin{tabular}{|c|c|c|c|c|c|c|}
\hline \multirow[t]{3}{*}{ Stack } & \multicolumn{2}{|c|}{ Annual $^{1}$} & \multicolumn{2}{|c|}{ Weekly $^{2}$} & \multicolumn{2}{|c|}{ Instantaneous ${ }^{3}$} \\
\hline & \multicolumn{6}{|c|}{$\mu \mathrm{Ci} / \mathrm{ml}$} \\
\hline & Alpha & Beta & Alpha & Beta & Alpha & Beta \\
\hline $\begin{array}{c}296-\mathrm{A}-17 \\
\& \\
296-\mathrm{P}-26\end{array}$ & $2.0 \mathrm{E}-13$ & $9.0 \mathrm{E}-11$ & N/A & N/A & $8.0 \mathrm{E}-13$ & $3.6 \mathrm{E}-10$ \\
\hline $295-A-25$ & $2.0 \mathrm{E}-14$ & $9.0 \mathrm{E}-12$ & $8.0 \mathrm{E}-14^{4}$ & $3.6 \mathrm{E}-11^{4}$ & $1.0 \mathrm{E}-10$ & $4.5 \mathrm{E}-08^{5}$ \\
\hline $296-A-27$ & $2.0 \mathrm{E}-13$ & $9.0 \mathrm{E}-11$ & $2.0 \mathrm{E}-13$ & $9.0 \mathrm{E}-11$ & $1.0 \mathrm{E}-10$ & $4.5 \mathrm{E}-08$ \\
\hline $296-A-29$ & $2.0 \mathrm{E}-13$ & $9.0 \mathrm{E}-11$ & $2.0 \mathrm{E}-13$ & $9.0 \mathrm{E}-11$ & $1.0 \mathrm{E}-10$ & $4.5 \mathrm{E}-08$ \\
\hline $296-A-40$ & $2.0 \mathrm{E}-14$ & $9.0 \mathrm{E}-12$ & $2.0 \mathrm{E}-13$ & $9.0 \mathrm{E}-11$ & $1.0 \mathrm{E}-10$ & $4.5 \mathrm{E}-08$ \\
\hline 296-B-28 & $2.0 \mathrm{E}-14$ & $9.0 \mathrm{E}-12$ & $8.0 \mathrm{E}-14^{4}$ & $3.6 \mathrm{E}-11^{4}$ & $1.0 \mathrm{E}-10$ & $4.5 \mathrm{E}-08^{5}$ \\
\hline $296-C-05$ & $2.0 \mathrm{E}-14$ & $9.0 \mathrm{E}-12$ & $8.0 \mathrm{E}-14^{4}$ & $3.6 \mathrm{E}-11^{4}$ & $1.0 \mathrm{E}-10$ & $4.5 \mathrm{E}-08$ \\
\hline $296-P-16$ & $2.0 \mathrm{E}-14$ & $9.0 \mathrm{E}-12$ & $8.0 \mathrm{E}-14^{4}$ & $3.6 \mathrm{E}-11^{4}$ & $1.0 \mathrm{E}-10$ & $4.5 E-08^{5}$ \\
\hline $\begin{array}{c}296-\mathrm{P}-23 \\
\& \\
296-\mathrm{P}-28\end{array}$ & $2.0 \mathrm{E}-14$ & $9.0 \mathrm{E}-12$ & $2.0 \mathrm{E}-13$ & $9.0 \mathrm{E}-11$ & $1.0 \mathrm{E}-10$ & $4.5 \mathrm{E}-08$ \\
\hline $296-S-15$ & $2.0 \mathrm{E}-14$ & $9.0 \mathrm{E}-12$ & $8.0 \mathrm{E}-14^{4}$ & $3.6 \mathrm{E}-11^{4}$ & $1.0 \mathrm{E}-10$ & $4.5 E-08^{5}$ \\
\hline
\end{tabular}


Table 7-1. Emission Limits. (2 sheets)

\begin{tabular}{|c|c|c|c|c|c|c|}
\hline \multirow[t]{3}{*}{ Stack } & \multicolumn{2}{|c|}{ Annual $^{1}$} & \multicolumn{2}{|c|}{ Weekly $^{2}$} & \multicolumn{2}{|c|}{ Instantaneous $^{3}$} \\
\hline & \multicolumn{6}{|c|}{$\mu \mathrm{Ci} / \mathrm{ml}$} \\
\hline & Alpha & Beta & Alpha & Beta & Alpha & Beta \\
\hline $296-S-22$ & $2.0 \mathrm{E}-14$ & $9.0 \mathrm{E}-12$ & $8.0 \mathrm{E}-14^{4}$ & $3.6 \mathrm{E}-11^{4}$ & $1.0 \mathrm{E}-10$ & 4.5E-08 \\
\hline $296-T-18$ & $2.0 \mathrm{E}-14$ & $9.0 \mathrm{E}-12$ & $8.0 \mathrm{E}-14^{4}$ & $3.6 \mathrm{E}-11^{4}$ & $1.0 \mathrm{E}-10$ & $4.5 \mathrm{E}-08^{5}$ \\
\hline $296-U-11$ & $2.0 \mathrm{E}-14$ & $9.0 \mathrm{E}-12$ & $8.0 \mathrm{E}-14$ & $3.6 \mathrm{E}-11^{4}$ & $1.0 \mathrm{E}-10$ & $4.5 \mathrm{E}-8^{5}$ \\
\hline
\end{tabular}

1 Annual limit $=1 *$ DCG

2 Weekly limit $=4 *$ DCG

3 Instantaneous limit $=5,000 *$ DCG (Averaged over $4 \mathrm{hrs}$ )

4 Refers to, two week average, not weekly

5 Refers to instantaneous, not over 4 hours 
The released volume, can be found from the flow rate of the effluent stream and the operating time of the system.

$$
\mathrm{V}_{\mathrm{k}}=\mathrm{Q}_{\mathrm{x}}{ }_{\mathrm{t}}
$$

where:

$Q_{k}$ is the flow rate, and

$t$ is the length of time that the system operated

Tr is therefore,

$$
\operatorname{Tr}=\rho_{\mathbf{k}}^{*} \mathrm{Q}_{\mathrm{r}}^{* \mathrm{t}}
$$

$\mathrm{Tr}$ is a quantity, normally expressed in units of $\mathrm{Ci}$. It is $\mathrm{Tr}$ that is important in emission reporting. If the CAMs are to be used as indicators of increased emissions, it is logical to assume, then, that the alarm set points should be based on increased quantities.

Alarm set points are established on concentrations. From equation 1 above, it is readily apparent that $\mathrm{Tr}$ is directly related to the concentration and the stack flow rate. Therefore, as long as the stack flow rate remains the same, increased emissions would be indicated by increased stack concentrations. The CAM can be used to indicate when this happens.

The CAM unit is designed to draw a portion of the stack effluent through a collection filter paper at certain sample flow rates. A radiation detector head is installed as part of the CAM unit and used to monitor the activity collected on this filter. The average concentration seen by the CAM is determined by dividing the activity seen by the CAM detector head by the sample flow volume, which is the sample flow rate multiplied by the time the system was collecting the sample. This is expressed mathematically as follows:

$$
\rho_{0}=\frac{A}{Q_{0} \times t}
$$

where:

$$
\begin{aligned}
& \rho_{0}=\text { the concentration of material seen in the CAM } \\
& A \quad=\text { the activity seen on the CAM's collection filter by the CAM's detector } \\
& \mathrm{Q}_{0}=\text { the flow rate through the CAM }
\end{aligned}
$$

The variable of interest, though, is that concentration in the stack - recall that an increase in the concentration being released is what the alarm set point should be set to. Therefore the variable of interest, as given in equation 1 is $\rho_{k}$. In order to assume that $\rho_{\mathrm{o}}$ (the 
concentration collected in the sample) is equivalent to $\rho_{\mathrm{k}}$ (the concentration in the stack), the losses and efficiencies must be known or estimated. The expression of these losses or efficiencies can be done as follows:

$$
\epsilon^{*} \rho_{\mathrm{k}}=\rho_{\mathrm{o}}
$$

Where $\epsilon$ represents the efficiency of the sample collection and detection process. $\epsilon$ can be further broken down as follows:

$$
\begin{aligned}
& \epsilon_{\mathrm{c}}=\text { the sample collection efficiency } \\
& \epsilon_{\mathrm{f}}=\text { the filter collection efficiency } \\
& \epsilon_{\mathrm{d}}=\text { the detector efficiency }
\end{aligned}
$$

where

$$
\epsilon=\epsilon_{\mathrm{c}}^{*} \epsilon_{\mathrm{f}}^{*} \epsilon_{\mathrm{d}}
$$

Recall that the variable of interest here is $\rho_{k}$, the concentration in the stack. With this:

$$
\rho_{k}=\frac{A}{Q_{0} \times t \times \epsilon_{c} \times \epsilon_{f} \times \epsilon_{d}}
$$

The CAM reads out in counts per minute (cpm), which is an activity. As such, the alarm set point can be set to "A", the activity collected on the filter paper. Solving for "A" now gives:

$$
\mathrm{A}=\rho_{\mathrm{k}} * \mathrm{Q}_{\mathrm{o}} * \mathrm{t} * \epsilon_{\mathrm{c}} * \epsilon_{\mathrm{f}} * \epsilon_{\mathrm{d}}
$$

DISCUSSION OF THE VARIABLES: Now that an appropriate equation is derived, a brief discussion of the variables involved is in order:

From the discussion above, $\rho_{\mathrm{k}}$ is usually expressed as a DCG or a DAC which has units of $\mu \mathrm{Ci} / \mathrm{ml}$.

$\epsilon_{\mathrm{d}}$ is the detector efficiency, expressed as a ratio of $\mathrm{cpm} / \mathrm{dpm}$ - dpm is the abbreviation for disintegrations per minute. Since $\rho_{\mathrm{x}}$ is expressed in units of $\mu \mathrm{Ci} / \mathrm{ml}$, a conversion factor is necessary to convert dpm to $\mu \mathrm{Ci}$. One $\mu \mathrm{Ci}$ is equivalent to $2.22 \mathrm{E}+06 \mathrm{dpm}$. $\epsilon_{\mathrm{d}}$ is determined in the field. WHC-IP-0718 (Appendix I), Section 4.2, Continuous Air Monitoring (WHC 1994a) gives instructions to reject the CAM if the efficiencies do not meet the criteria given, or if any of the alarm circuitry is inoperable. The efficiencies given $\left(\epsilon_{d}\right)$ are:

Alpha CAM efficiency performance should always be $>7 \%$ and $<20 \%$. 
Beta CAM efficiency performance should always be $>10 \%$ for $\mathrm{Cs}^{137}$, and $>15 \%$ for $\mathrm{Sr}-\mathrm{Y}^{90}$.

$\epsilon_{\mathrm{f}}$ is the collection efficiency of the filter paper. The manufacturers efficiency given for the VERSAPOR 3000 filter paper is $91 \%$. If another filter paper is used, the corresponding manufacturer's efficiency rating must be used.

$\epsilon_{c}$ is the collection efficiency of the sample probe and transport line. These values have been derived in WHC-SD-WM-ES-291, Rev. 1 (WHC 1994e). These values are however dependant upon the particle size. For purposes of calculating the alarm set point of the CAM, there are two possible particle sizes which might be used to ascertain the possible collection efficiency factor to use. These are as follows:

- During normal operation, there is no reason to assume that the particles will be large. WHC-SD-WM-ES-291, Rev. 1 justified use of a $3.5 \mu \mathrm{m}$ sized particles for collection efficiencies.

- If the HEPAs were to fail, however, large particles might exist in the effluent stream. As such, the correct efficiency factor to use would be for the $10 \mu \mathrm{m}$ sized particles. These collection efficiencies are given in WHC-SD-WM-ES-291, Rev. 1 as follows:

$\begin{array}{lcc}\text { Stack } & \epsilon_{c} \text { for } 3.5 \mu \mathrm{m} & \epsilon_{\text {c for } 10 \mu \mathrm{m}} \\ 296-\mathrm{A}-17 & 0.775 & 0.014 \\ 296-\mathrm{P}-26 & 0.927 & 0.572 \\ 296-\mathrm{A}-25 & 0.894 & 0.493 \\ 296-\mathrm{A}-27 & 0.574 & 0.000 \\ 296-\mathrm{A}-29 & 0.586 & 0.002 \\ 296-\mathrm{A}-40 & 0.875 & 0.375 \\ 296-\mathrm{B}-28 & 0.788 & 0.036 \\ 296-\mathrm{C}-05 & 0.916 & 0.525 \\ 296-\mathrm{P}-16 & 0.866 & 0.384 \\ 296-\mathrm{P}-23 & 0.866 & 0.361 \\ 296-\mathrm{P}-28 & 0.839 & 0.177 \\ 296-\mathrm{S}-15 & 0.923 & 0.486 \\ 296-\mathrm{S}-22 & 0.787 & 0.092 \\ 296-\mathrm{T}-18 & 0.769 & 0.088 \\ 296-\mathrm{U}-11 & \ldots * & 0.856\end{array}$

"*Collection efficiency has not been calculated.

The variable " $t$ " is the time the sampler/monitor was running - this is, of course, the time since a fresh, clean filter was installed. " $t$ " is usually expressed in units of hours. 
$\mathrm{Q}_{0}$ is the variable for the sample flow rate. Normally this variable is set to $6 \mathrm{E}-2 \mathrm{~m}^{3}$ $\left(2 \mathrm{ft}^{3}\right)$ per minute or $3.4 \mathrm{~m}^{3}\left(120 \mathrm{ft}^{3}\right)$ per hour (abbreviated as CFH). Since, $\rho_{\mathrm{k}}$ is expressed in units of $\mu \mathrm{Ci} / \mathrm{ml}$, a conversion factor is necessary, to use the CFH unit in this equation. One $\mathrm{ft}^{3}$ is equivalent to $2.83168 \mathrm{E}+04 \mathrm{ml}$.

With the variables defined and the conversion factors determined, equation 3 can be rewritten as follows:

$$
\begin{aligned}
A & =\rho_{\mathrm{r}}{ }^{*} \mathrm{Q}_{\mathrm{o}}{ }^{*} \mathrm{t}^{*} \epsilon_{\mathrm{c}}{ }^{*} \epsilon_{\mathrm{f}}{ }^{*} \epsilon_{\mathrm{d}}{ }^{*} 2.832 \mathrm{E}+04 \mathrm{ml} / \mathrm{ft}^{3} * 2.22 \mathrm{E}+06 \mathrm{dpm} / \mu \mathrm{Ci} \\
& =\rho_{\mathrm{r}}{ }^{*} \mathrm{Q}_{\mathrm{o}}{ }^{*} \mathrm{t}^{*} \epsilon_{\mathrm{c}}{ }^{*} \epsilon_{\mathrm{f}}{ }^{*} \epsilon_{\mathrm{d}}{ }^{*} 6.286 \mathrm{E}+10(\mathrm{ml})(\mathrm{dpm}) /\left(\mathrm{ft}^{3}\right)(\mu \mathrm{Ci})
\end{aligned}
$$

Another way to express this is to put the conversion factor into the denominator as follows:

$$
A=\frac{\rho_{k} \times Q_{0} \times t \times \epsilon_{c} \times \epsilon_{f} \times \epsilon_{d}(d p m)(m l)}{1.591 \times 10^{-11}\left(\mathrm{ft}^{3}\right)(u C i)}
$$

Note that in equation 4 , one still has to put the units in for variables $\rho_{k}, Q_{o}, t$, and $\epsilon_{d}$. These units should be:

- $\mu \mathrm{Ci} / \mathrm{ml}$ for $\rho_{\mathrm{k}}$

- $\quad \mathrm{CFH}$ for $\mathrm{Q}_{0}$

- hrs for $\mathrm{t}$

- $\epsilon_{\mathrm{d}} \mathrm{cpm} / \mathrm{dpm}$.

A similar equation to equation 4 is given in WHC-IP-0718 (Appendix I), Section 4.2 (WHC 1994a) as:

$$
A S P=\frac{(\mathrm{DAC})(\mathrm{V})(\mathrm{E})(\mathrm{DAC}-\mathrm{hrs})}{2 \mathrm{E}-11}
$$

where:
ASP $\quad=\quad$ Alarm Set Point (cpm)
DAC $=$ Derived Air Concentration for the isotope of concern $(\mu \mathrm{Ci} / \mathrm{ml})$
$\mathrm{V}=$ Flow rate of the air through the CAM $\left(\mathrm{ft}^{3} / \mathrm{hr}\right)$
$\mathrm{E}=\mathrm{CAM}$ counting efficiency (decimal form, cpm/dpm) 
DAC-hrs $=$ Value retrieved from the Appendix of WHC-IP-0718

$2 \mathrm{E}-11=$ Conversion constant $\left(\mu \mathrm{Ci} \cdot \mathrm{ft}^{3} / \mathrm{dpm} \cdot \mathrm{ml}\right)$

Note that equation 5 identical to equation 4 except for the conversion factor of $2 \mathrm{E}-11$ and a couple efficiency factors. This is because the missing efficiency factors in equation 5 have been combined into the conversion factor. In fact the conversion factor of $2 \mathrm{E}-11$ is different from that in equation 4 by about a factor of 0.8 . This means that in the derivation of equation $4, \epsilon_{\mathrm{c}}$ and $\epsilon_{\mathrm{f}}$ were assumed to be equivalent to about 0.8 .

\subsubsection{Determination of Alarm Set Points}

As noted in Section 7.2.1, emission limits are established on annual, weekly/two week, and for the OSD, instantaneous bases. These limits are established because the regulations are concerned with increased emissions. Annual limits are easily verified as being in or out with review of the annual reports. The weekly values are not so easily viewed, however, unless one has access to the laboratory analysis values. It can be done though. Therefore, it is suggested that the CAM alarm set points be set as low as possible without spurious alarms, but between the weekly and instantaneous limits. The following table provides these alarm set points. Set points for both the weekly and instantaneous emission limits are provided. For illustrative purposes, the EDE for the public due to the instantaneous limit being violated for an entire year is also provided. The alarm set points were calculated using the following values and assumptions:

- The weekly and instantaneous values given in the Table 7-1 were used in the variable $\rho_{\mathbf{k}}$.

- A value of $3.4 \mathrm{~m}^{3} / \mathrm{hr}(120 \mathrm{CFH})$ was used for the variable $Q_{0}$.

- A value of 168 hours was used for the variable " $t$ " in the weekly calculations. A value of 336 was used for " $t$ " in the cases were the limit is specified to be for two week averages.

- A value of 4 hours was used for the variable " $t$ " in the instantaneous calculations. A value of 1 hour was used for " $t$ " in those cases where no hourly limit was mentioned in the OSDs.

- The values used for the variable $\epsilon_{\mathrm{c}}$ were those listed in Section 7.2.2 above for each specific stack. The values for $\epsilon_{\mathrm{c}}$ for $10 \mu \mathrm{m}$ were used in cases were it was assumed that increased emissions were caused by a HEPA filter failure or some other cause creating large particles.

- The value of 0.91 was used the variable $\epsilon_{\mathrm{f}}$. 
- The lowest beta efficiency factor for Sr-90 of 0.15 was used for the variable $\epsilon_{d}$ in the beta CAM alarm set point calculations.

- The lowest alpha efficiency factor of 0.07 was used for the variable $\epsilon_{d}$ in the alpha CAM alarm set point calculations.

- The following maximum $95 \%$ confidence interval flow rate values were used to calculate the resultant public EDE due to a continual maximum instantaneous release for the entire year:

\begin{tabular}{|c|c|c|}
\hline Stack & Max flow (ft $\left.{ }^{3} / \mathrm{min}\right)$ & Max flow (L/yr) \\
\hline $296-\mathrm{A}-17$ & 3,838 & $5.7 \mathrm{E}+10$ \\
\hline $296-\mathrm{P}-26$ & 5,816 & $-8.7 \mathrm{E}+10$ \\
\hline $296-\mathrm{A}-25$ & 233 & $3.5 \mathrm{E}+09$ \\
\hline $296-\mathrm{A}-27$ & 1,289 & $1.9 \mathrm{E}+10$ \\
\hline $296-\mathrm{A}-29$ & 887 & $1.3 \mathrm{E}+10$ \\
\hline $296-\mathrm{A}-40$ & 1,311 & $2.0 \mathrm{E}+10$ \\
\hline $296-\mathrm{B}-28$ & 289 & $4.3 \mathrm{E}+09$ \\
\hline $296-\mathrm{C}-05$ & 4,885 & $7.3 \mathrm{E}+10$ \\
\hline $296-\mathrm{P}-16$ & 3,993 & $5.9 \mathrm{E}+10$ \\
\hline $296-\mathrm{P}-23$ & 1,076 & $1.6 \mathrm{E}+10$ \\
\hline $296-\mathrm{P}-28$ & 954 & $1.4 \mathrm{E}+10$ \\
\hline $296-\mathrm{S}-15$ & 6,527 & $9.7 \mathrm{E}+10$ \\
\hline $296-\mathrm{S}-22$ & 174 & $* 2.6 \mathrm{E}+09$ \\
\hline $296-\mathrm{T}-18$ & 398 & $5.9 \mathrm{E}+09$ \\
\hline $296-\mathrm{U}-11$ & $* *$ & $* *$ \\
\hline
\end{tabular}

* Refers to maximum, not confidence.

**Max flow has not been determined

It is suggested that the CAM alarm set points be set as low as possible without spurious alarms, but between the weekly and instantaneous values listed in Table 7-2. 
Table 7-2. CAM Alarm Set Point. (3 sheets)

\begin{tabular}{|c|c|c|c|c|c|}
\hline \multirow[t]{2}{*}{ Stack/CAM } & \multicolumn{2}{|c|}{$\epsilon_{\mathrm{c}}$ for $10 \mu \mathrm{m}$} & \multicolumn{2}{|c|}{$\epsilon_{\mathrm{c}}$ for $3.5 \mu \mathrm{m}$} & \multirow{2}{*}{$\begin{array}{c}\mathrm{EDE}^{1} \\
\text { (mrem/yr) }\end{array}$} \\
\hline & $\begin{array}{l}\text { Weekly } \\
\text { (cpm) }\end{array}$ & $\begin{array}{l}\text { Instantaneous } \\
\text { release } \\
(\mathrm{cpm})\end{array}$ & $\begin{array}{c}\text { Weekly } \\
\text { (cpm) }\end{array}$ & $\begin{array}{c}\text { Instantaneous } \\
\text { release } \\
\text { (cpm) }\end{array}$ & \\
\hline $\begin{array}{c}\text { 296-A-17 } \\
\text { Beta CAM }\end{array}$ & N/A & 21 & N/A & 1,100 & 8.8E-04 \\
\hline $\begin{array}{c}296-P-26 \\
\text { Beta CAM }\end{array}$ & N/A & 850 & N/A & 1,400 & $1.4 \mathrm{E}-03$ \\
\hline $\begin{array}{c}296-A-25 \\
\text { Beta CAM }\end{array}$ & 6,100 & 23,000 & 11,000 & 41,000 & $1.7 \mathrm{E}-03$ \\
\hline $\begin{array}{c}296-A-27 \\
\text { Beta CAM }\end{array}$ & 0 & 0 & 8,900 & 110,000 & 0.037 \\
\hline $\begin{array}{c}\text { 296-A-29 } \\
\text { Beta CAM }\end{array}$ & 31 & 370 & 9,100 & 110,000 & 0.026 \\
\hline $\begin{array}{c}296-A-40 \\
\text { Beta CAM }\end{array}$ & 5,800 & 69,000 & 14,000 & 160,000 & 0.039 \\
\hline $\begin{array}{c}\text { 296-B-28 } \\
\text { Beta CAM }\end{array}$ & 450 & 1,700 & 9,800 & 37,000 & $2.1 \mathrm{E}-03$ \\
\hline
\end{tabular}




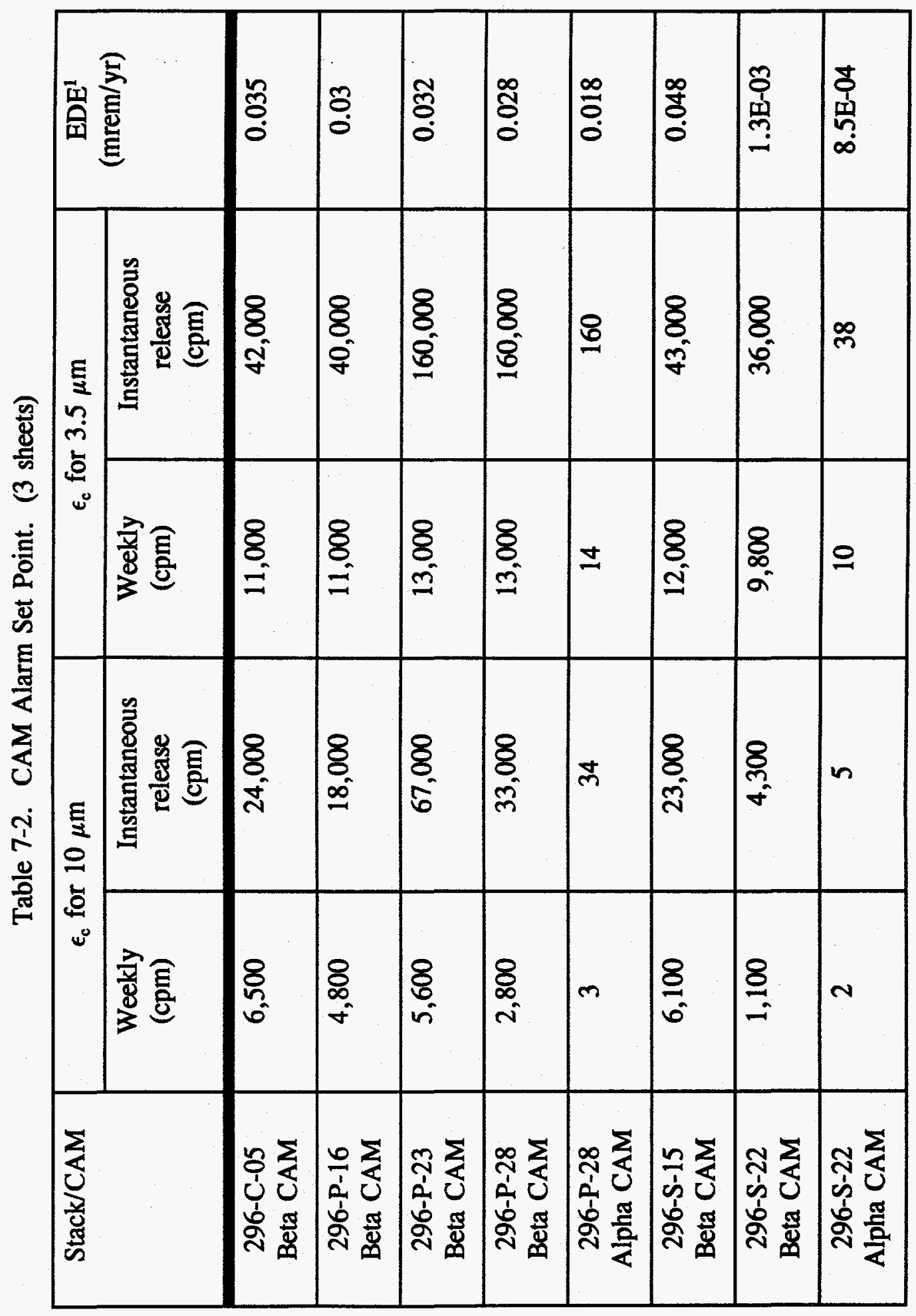


Table 7-2. CAM Alarm Set Point. (3 sheets)

\begin{tabular}{|c|c|c|c|c|c|}
\hline \multirow{2}{*}{ Stack/CAM } & \multicolumn{2}{|c|}{$\epsilon_{\mathrm{c}}$ for $10 \mu \mathrm{m}$} & \multicolumn{2}{c|}{$\epsilon_{\mathrm{c}}$ for $3.5 \mu \mathrm{m}$} & \multirow{2}{*}{\begin{tabular}{|c|c|}
$\mathrm{EDE}^{1}$ \\
(mrem/yr)
\end{tabular}} \\
\cline { 2 - 5 } & $\begin{array}{c}\text { Weekly } \\
(\mathrm{cpm})\end{array}$ & $\begin{array}{c}\text { Instantaneous } \\
\text { release } \\
(\mathrm{cpm})\end{array}$ & $\begin{array}{c}\text { Weekly } \\
(\mathrm{cpm})\end{array}$ & $\begin{array}{c}\text { Instantaneous } \\
\text { release } \\
(\mathrm{cpm})\end{array}$ & \\
\hline $\begin{array}{c}296-\mathrm{T}-18 \\
\text { Beta CAM }\end{array}$ & 1,100 & 4,100 & 9,600 & 36,000 & $3.0 \mathrm{E}-03$ \\
\hline $\begin{array}{c}296-\mathrm{T}-18 \\
\text { Alpha CAM }\end{array}$ & 1 & 4 & 10 & 37 & $1.9 \mathrm{E}-03$ \\
\hline $\begin{array}{c}\text { 296-U-11 } \\
\text { Beta CAM }\end{array}$ & 2,500 & 19,000 & 2 & 2 & 3 \\
\hline
\end{tabular}

${ }^{1}$ Consequence if the average release equaled the instantaneous release continuously for an entire year.

${ }^{2}$ Alarm set points for $3.5 \mu \mathrm{m}$ size particles were not calculated because the $10 \mu \mathrm{m}$ size particle is the most limiting case.

${ }^{3}$ The offsite dose has not been estimated for a continuous release at the instantaneous alarm set point, however, the dose would be approximately equal to the dose estimated for the 296-T-18 Stack. 


\subsubsection{Interpretation of Alarm Set Points}

\section{NORMAL RELEASE ALARM SETTINGS}

It should be understood that the alarm set point values given for $\epsilon_{\mathrm{c}}$ for $10 \mu \mathrm{m}$ in the table above represent those settings necessary to indicate large particle releases at the weekly and instantaneous limits. These values are a result of using the lowest possible value for $\epsilon_{\mathrm{c}}$ calculated for $10 \mu \mathrm{m}$ sized particles. Under normal circumstances, however, large particles may not be present. The word "may" is used because no particle size studies have been accomplished in these stacks. As noted in Section 7.2.2 under the heading "Discussion of the Variables" during normal circumstances a $3.5 \mu \mathrm{m}$ sized particle has been justified.

\section{INTERPRETATION OF ALARMS AND CAM READOUTS}

In interpreting the CAM's readouts and alarm settings, it is important to understand the mechanism at work. The CAMs do not read the concentration directly. They read the activity collected since a new, clean collection filter was installed. The following is provided to illustrate the importance of understanding this:

- Assume that the CAM alarm set point has been set to the 4 hour release of 5000 times the DCG.

- The collection filters are normally exchanged weekly (168 hours). Assume, then, that the alarm annunciated just before change out.

- Interpretation: A 4-hour release at 5000 times the DCG (for Sr-90) amounts to an average release concentration of $4.5 \mathrm{E}-08 \mu \mathrm{Ci} / \mathrm{ml}$. But if the alarm did not annunciate until just before the filter was exchanged (168 hours), the actual concentration released would have averaged $1.07 \mathrm{E}-09 \mu \mathrm{Ci} / \mathrm{ml}$ - a much lower concentration.

The intent of this illustration was to make it apparent that interpretation of the reading of the CAM or an alarm indication is dependant upon the length of time the collection filter has been in place.

\section{CONVERSION OF ALARMS AND CAM READOUTS TO ACTUAL RELEASES}

As noted above, the concentration seen in the sampling system is not, necessarily, that present in the stack effluent unless the losses or efficiencies have been accounted for. Equation 2 was provided to accomplish this. This equation can be used to estimate the concentration in the stack from the readout of the CAM or to signify what alarm set point 
would represent a particular stack concentration. To quantify this concentration, however, it is necessary to combine equation 2 with equation 1 . Equation 6 provides that combination.

$$
T_{r}=\frac{A \times Q_{k} \times t_{k}}{Q_{o} \times t_{o} \times \epsilon_{c} \times \epsilon_{f} \times \epsilon_{d}}
$$

where:

$t_{0}=$ the length of time that a clean filter paper has been installed. It is important to understand that if the alarm goes off, $t_{0}$ is the length of time the filter has been installed, not the time used to calculate the alarm set point.

$\mathbf{t}_{\mathbf{k}}=$ the length of time that the exhaust fan has been operating. For purposes of estimating emissions during the time the filter was in place, $t_{4}$ would be equal to $t_{0}$. In this case time cancels out of the equation. The two " $t$ " variables are useful, however, if one wants to know the resulting emissions for longer periods of time at specific CAM settings or readouts.

\subsection{SPECIFIC STACK SAMPLING/MONITORING INSTRUMENTATION}

Tables 7-3 through 7-28 list the current instrument number and the Component Based Recall System (CBRS) number for applicable stacks sampling/monitoring systems discussed in this FEMP. The CBRS is the current system used to track and schedule instrument maintenance. Contained within the CBRS database are the maintenance procedures, last done and next due maintenance dates, and frequency.

Instruments currently contained in the CBRS system will soon be transferred into the Job Control System (JCS) PM module. 
Table 7-3. Stack 296-A-17: 241-AY/AZ Tank Farms Exhauster - Beta/gamma Loop.

\begin{tabular}{|l|l|c|}
\hline \multicolumn{1}{|c|}{ Instrument } & Instrument No. & CBRS Loop \\
\hline Vacuum gauge & PI-CAM-702-1 & 2A 054 2 \\
\hline Flow switch & FAS-Cam-702-1 & 2A 054 3 \\
\hline
\end{tabular}

Table 7-4. Stack 296-A-17: 241-AY/AZ Tank Farms Exhauster - Record Sampler Loop.

\begin{tabular}{|l|l|c|}
\hline \multicolumn{1}{|c|}{ Instrument } & \multicolumn{1}{|c|}{ Instrument No. } & CBRS Loop \\
\hline Rotameter & FI-RS-702-2 & 2A 053 1 \\
\hline Gasmeter & FIQ-RS-702-2 & 2A 053 3 \\
\hline Vacuum gauge & PI-RS-702-2 & 2A 053 4 \\
\hline Flow switch & FAS-RS-702-2 & 2A 053 5 \\
\hline
\end{tabular}

Table 7-5. Stack 296-P-26: 241-AY/AZ Tank Farms Backup Exhauster - Beta/gamma Loop.

\begin{tabular}{|l|l|c|}
\hline \multicolumn{1}{|c|}{ Instrument } & \multicolumn{1}{|c|}{ Instrument No. } & CBRS Loop \\
\hline Vacuum gauge & PI-EXH-PE-2 & 2A 062 2 \\
\hline Flow switch & FAS-EXH-PE-2 & 2A 062 3 \\
\hline
\end{tabular}

Table 7-6. Stack 296-P-26: 241-AY/AZ Tank Farms Backup Exhauster - Record Sampler Loop.

\begin{tabular}{|l|l|c|}
\hline \multicolumn{1}{|c|}{ Instrument } & \multicolumn{1}{|c|}{ Instrument No. } & CBRS Loop \\
\hline Rotameter & FI-EXH-PE-1 & 2A 061 1 \\
\hline Gasmeter & FQI-EXH-PE-1 & 2A 061 2 \\
\hline Vacuum gauge & PI-EXH-PE-1 & 2A 061 3 \\
\hline Flow switch & FAS-EXH-PE-1 & 2A 061 4 \\
\hline
\end{tabular}


Table 7-7. Stack 296-A-25: 244-A Double-Contained Receiver Tank Exhauster - Beta/gamma Loop.

\begin{tabular}{|l|l|c|}
\hline \multicolumn{1}{|c|}{ Instrument } & \multicolumn{1}{|c|}{ Instrument No. } & CBRS Loop \\
\hline Vacuum gauge & PI-EXH-2 & 4A 30B 2 \\
\hline Flow switch & FAS-EXH-2 & 4A 30B 3 \\
\hline
\end{tabular}

Table 7-8. Stack 296-A-25: 244-A Double-Contained Receiver Tank Exhauster - Record Sampler Loop.

\begin{tabular}{|l|l|c|}
\hline \multicolumn{1}{|c|}{ Instrument } & \multicolumn{1}{|c|}{ Instrument No. } & CBRS Loop \\
\hline Rotameter & FI-EXH-1 & 4A 30A 1 \\
\hline Gasmeter & FQI-EXH-1 & 4A 30A 3 \\
\hline Vacuum gauge & PI-EXH-1 & 4A 30A 4 \\
\hline Flow switch & FAS-EXH-1 & 4A 30A 5 \\
\hline
\end{tabular}

Table 7-9. Stack 296-A-27: 241-AW Tank Farm Exhauster Beta/gamma Loop.

\begin{tabular}{|l|l|c|}
\hline \multicolumn{1}{|c|}{ Instrument } & \multicolumn{1}{|c|}{ Instrument No. } & CBRS Loop \\
\hline Vacuum gauge & PI-EXH-K1-2 & AW 311 1 \\
\hline Flow switch & FAS-EXH-K1-2 & AW 311 2 \\
\hline
\end{tabular}

Table 7-10. Stack 296-A-27: 241-AW Tank Farm Exhauster Record Sampler Loop.

\begin{tabular}{|l|l|c|}
\hline \multicolumn{1}{|c|}{ Instrument } & \multicolumn{1}{|c|}{ Instrument No. } & CBRS Loop \\
\hline Rotameter & FI-EXH-K1-1 & AW 312 1 \\
\hline Gasmeter & FQI-EXH-K1-1 & AW 312 2 \\
\hline Vacuum gauge & PI-EXH-K1-1 & AW 312 3 \\
\hline Flow switch & FAS-EXH-K1-1 & AW 312 4 \\
\hline
\end{tabular}


Table 7-11. Stack 296-A-29: 241-AN Tank Farm Exhauster Beta/gamma Loop.

\begin{tabular}{|r|l|c|}
\hline Instrument & Instrument No. & CBRS Loop \\
\hline Pressure switch & PS-EXH-K1-1 & AN 038 2 \\
\hline
\end{tabular}

Table 7-12. Stack 296-A-29: 241-AN Tank Farm Exhauster Record Sampler Loop.

\begin{tabular}{|l|l|c|}
\hline \multicolumn{1}{|c|}{ Instrument } & \multicolumn{1}{|c|}{ Instrument No. } & CBRS Loop \\
\hline Rotameter & FI-RS-K1 & AN 039 2 \\
\hline Gasmeter & FQI-EXH-K1 & AN 039 1 \\
\hline Pressure switch & PS-EXH-K1-2 & AN 039 3 \\
\hline
\end{tabular}

Table 7-13. Stack 296-A-40: 241-AP Tank Farm Exhauster Beta/gamma Loop.

\begin{tabular}{|l|l|c|}
\hline \multicolumn{1}{|c|}{ Instrument } & \multicolumn{1}{|c|}{ Instrument No. } & CBRS Loop \\
\hline Vacuum gauge & PI-K1-3-1 & AP 305 B \\
\hline Flow switch & FAS-K1-3-1 & AP 305 8 \\
\hline
\end{tabular}

Table 7-14. Stack 296-A-40: 241-AP Tank Farm Exhauster Record Sampler Loop.

\begin{tabular}{|l|l|c|}
\hline \multicolumn{1}{|c|}{ Instrument } & \multicolumn{1}{|c|}{ Instrument No. } & CBRS Loop \\
\hline Rotameter & FI-K1-2-1 & AP 301 1 \\
\hline Gasmeter & FQI-K1-2-1 & AP 301 2 \\
\hline Vacuum gauge & PI-K1-1 & AP 301 3 \\
\hline Flow switch & FAS-K1-2-1 & AP 301 4 \\
\hline
\end{tabular}


Table 7-15. Stack 296-B-28: 244-BX Double Contained Receiver Tank Exhauster - Record Sampler Loop.

\begin{tabular}{|l|l|c|}
\hline \multicolumn{1}{|c|}{ Instrument } & \multicolumn{1}{c|}{ Instrument No. } & CBRS Loop \\
\hline Rotameter & FI-5 & 4B 045 1 \\
\hline Gasmeter & FI-9 & 4B 045 2 \\
\hline Flow switch & PS-244BX-4 & 4B 045 3 \\
\hline Flow switch & PS-244BX-3 & 4B 045 4 \\
\hline
\end{tabular}

Table 7-16. Stack 296-C-05: 244-CR Vault Exhauster Beta/gamma Loop.

\begin{tabular}{|l|l|c|}
\hline \multicolumn{1}{|c|}{ Instrument } & \multicolumn{1}{|c|}{ Instrument No. } & CBRS Loop \\
\hline Vacuum gauge & PI-CAM-2 & CR 0852 \\
\hline Flow switch & FAS-CAM-2 & CR 085 1 \\
\hline
\end{tabular}

Table 7-17. Stack 296-C-05: 244-CR Vault Exhauster Record Sampler Loop.

\begin{tabular}{|l|l|c|}
\hline \multicolumn{1}{|c|}{ Instrument } & \multicolumn{1}{|c|}{ Instrument No. } & CBRS Loop \\
\hline Rotameter & FI-RS-1 & CR 0831 \\
\hline Gasmeter & FQI-RS-1 & CR 0832 \\
\hline Vacuum gauge & PI-RS-1 & CR 0831 \\
\hline Flow switch & FAS-RS-1 & CR 0834 \\
\hline
\end{tabular}

Table 7-18. Stack 296-P-16: 241-C-105/106 Tank Exhauster Beta/gamma Loop.

\begin{tabular}{|l|l|c|}
\hline \multicolumn{1}{|c|}{ Instrument } & \multicolumn{1}{|c|}{ Instrument No. } & CBRS Loop \\
\hline Vacuum gauge & PI-CAM-2 & P 1624 2 \\
\hline Flow switch & FAS-CAM-2 & P 1624 1 \\
\hline
\end{tabular}


Table 7-19. Stack 296-P-16: 241-C-105/106 Tank Exhauster Record Sampler Loop.

\begin{tabular}{|l|l|c|}
\hline \multicolumn{1}{|c|}{ Instrument } & \multicolumn{1}{|c|}{ Instrument No. } & CBRS Loop \\
\hline Rotameter & FI-RS-1 & P 1625 1 \\
\hline Gasmeter & FQI-RS-1 & P 1625 2 \\
\hline Vacuum gauge & PI-RS-1 & P 1625 3 \\
\hline Flow switch & FAS-RS-1 & P 1625 4 \\
\hline
\end{tabular}

Table 7-20. Stack 296-P-23: 241-SY Tank Farm Exhauster Beta/gamma Loop.

\begin{tabular}{|l|l|c|}
\hline \multicolumn{1}{|c|}{ Instrument } & \multicolumn{1}{c|}{ Instrument No. } & CBRS Loop \\
\hline Vacuum gauge & PI-K1-1-2 & SY 004 3 \\
\hline Flow switch & FAS-EXH-K1-1-2 & SY 004 1 \\
\hline
\end{tabular}

Table 7-21. Stack 296-P-23: 241-SY Tank Farm Exhauster Record Sampler Loop.

\begin{tabular}{|l|l|c|}
\hline \multicolumn{1}{|c|}{ Instrument } & \multicolumn{1}{|c|}{ Instrument No. } & CBRS Loop \\
\hline Rotameter & FI-EXH-K1-1 & SY 006 1 \\
\hline Gasmeter & FQI-EXH-K1-1 & SY 006 2 \\
\hline Vacuum gauge & PI-K1-1-1 & SY 006 5 \\
\hline Flow switch & FAS-EXH-K1-1-1 & SY 006 4 \\
\hline
\end{tabular}

Table 7-22. Stack 296-P-28: 241-SY Tank Farm Backup Exhauster - Alpha Loop.

\begin{tabular}{|l|l|c|}
\hline \multicolumn{1}{|c|}{ Instrument } & \multicolumn{1}{|c|}{ Instrument No. } & CBRS Loop \\
\hline Vacuum gauge & PI-P28-1 & P 2820 2 \\
\hline Flow switch & FAS-P28-1 & P 2820 1 \\
\hline
\end{tabular}


Table 7-23. Stack 296-P-28: 241-SY Tank Farm Backup Exhauster - Beta/gamma Loop.

\begin{tabular}{|l|l|c|}
\hline \multicolumn{1}{|c|}{ Instrument } & \multicolumn{1}{|c|}{ Instrument No. } & CBRS Loop \\
\hline Vacuum gauge & PI-P28-2 & P 2825 2 \\
\hline Flow switch & FAS-P28-2 & P 2825 1 \\
\hline
\end{tabular}

Table 7-24. Stack 296-P-28: 241-SY Tank Farm Backup Exhauster - Record Sampler Loop.

\begin{tabular}{|l|l|c|}
\hline \multicolumn{1}{|c|}{ Instrument } & \multicolumn{1}{|c|}{ Instrument No. } & CBRS Loop \\
\hline Rotameter & FI-P28-2 & P 2827 1 \\
\hline Gasmeter & FQI & P 2827 2 \\
\hline Vacuum gauge & PI-P28-3 & P 2827 4 \\
\hline Flow switch & FAS-P28-3 & P 2827 3 \\
\hline
\end{tabular}

Table 7-25. Stack 296-S-15: 241-SX Tank Farm Exhauster - Beta/gamma Loop.

\begin{tabular}{|l|l|c|}
\hline \multicolumn{1}{|c|}{ Instrument } & \multicolumn{1}{|c|}{ Instrument No. } & CBRS Loop \\
\hline Vacuum gauge & PI-CAM-2 & SX 0012 \\
\hline Flow switch & FAS-CAM-2 & SX 001 1 \\
\hline
\end{tabular}

Table 7-26. Stack 296-S-15: 241-SX Tank Farm Exhauster Record Sampler Loop.

\begin{tabular}{|l|l|c|}
\hline \multicolumn{1}{|c|}{ Instrument } & \multicolumn{1}{|c|}{ Instrument No. } & CBRS Loop \\
\hline Rotameter & FI-RS-1 & SX 013 1 \\
\hline Gasmeter & FQI-RS-1 & SX 013 2 \\
\hline Vacuum gauge & PI-RS-1 & SX 013 3 \\
\hline Flow switch & FAS-RS-1 & SX 013 4 \\
\hline
\end{tabular}


Table 7-27. Stack 296-S-22: 244-S Double-Contained Receiver

Tank Exhauster - Record Sampler, Alpha, and Beta/Gamma

Parallel Loops.

\begin{tabular}{|l|l|c|}
\hline \multicolumn{1}{|c|}{ Instrument } & \multicolumn{1}{|c|}{ Instrument No. } & CBRS Loop \\
\hline Rotameter & FI-1 & 4S 065 1 \\
\hline Gasmeter & FI-2 & 4S 065 2 \\
\hline Vacuum Gauge & PI-EXH-3 & 4S 065 3 \\
\hline Vacuum Gauge & PI-EXH-2 & 4S 065 4 \\
\hline Vacuum Gauge & PI-EXH-1 & 4S 065 5 \\
\hline Pressure Switch & PS-EXH-3 & 4S 065 6 \\
\hline Pressure Switch & PS-EXH-2 & 4S 065 7 \\
\hline Pressure Switch & PS-EXH-1 & 4S 065 8 \\
\hline
\end{tabular}

Table 7-28. Stack 296-T-18: 244-TX Double-Contained Receiver

Tank Exhauster - Record Sampler, Alpha, and Beta/Gamma Parallel Loop.

\begin{tabular}{|l|l|c|}
\hline \multicolumn{1}{|c|}{ Instrument No. } & \multicolumn{1}{|c|}{ Instrument No. } & CBRS Loop \\
\hline Rotameter & FI-244-TX-5 & 4T 312 1 \\
\hline Gasmeter & $\begin{array}{l}\text { FI-244-TX-9PI-EXH- } \\
9\end{array}$ & 4T 312 2 \\
\hline Pressure switch & PS-244-TX-4 & 4T 312 3 \\
\hline Pressure switch & PS-244-TX-3 & 4T 312 4 \\
\hline Pressure switch & PS-244-TX-2 & 4T 312 5 \\
\hline
\end{tabular}


Table 7-29. Stack 296-U-11: 244-U Double Contained Receiver

Tank Exhauster - Record Sample, Beta/Gamma Parallel Loops.

\begin{tabular}{|l|l|l|}
\hline \multicolumn{1}{|c|}{ Instrument } & \multicolumn{1}{c|}{ Instrument No. } & CBRS Loop $^{1}$ \\
\hline Chart recorder & XR-244-U-1 & \\
\hline Flow totalizer & FT-244-U-3 & \\
\hline Flow totalizer & FT-244-U-4 & \\
\hline Flow totalizer & FT-244-U-5 & \\
\hline Pressure switch & PS-244-U-3 & \\
\hline Pressure switch & PS-244-U-4 & \\
\hline Pressure controller & PS-244-U-4 & \\
\hline
\end{tabular}

${ }^{1}$ Not assigned 
WHC-EP-0479-1

\subsection{EMISSION DATA}

Emission data are compiled and reported each year. The following is a list of the emission reports for the past several years.

- WHC-EP-0141, Westinghouse Hanford Company Effluent Discharges and Solid Waste Management Report for 1987: 200/600/1100 Areas (WHC 1988)

- WHC-EP-0141-1, Westinghouse Hanford Company Effluent Discharges and Solid Waste Management Report for 1988: 200/600/1100 Areas (WHC 1989a)

- WHC-EP-0141-2, Westinghouse Hanford Company Effluent Discharges and Solid Waste Management Report for 1989: 200/600/1100 Areas (WHC 1990)

- DOE/RL-91-10, Calendar year 1990 Air Emissions Report for the Hanford Site (DOE/RL 1991)

- DOE/RL-92-30, Radionuclide Air Emission Report for the Hanford Site Calendar Year 1991 (DOE/RL 1992)

- DOE/RL-93-36, Radionuclide Air Emission Report for the Hanford Site Calendar Year 1992 (DOE/RL 1993)

- DOE/RL-94-51, Radionuclide Air Emission Report for the Hanford Site Calendar Year 1993 (DOE/RL 1994) 
WHC-EP-0479-1

This page intentionally left blank. 


\subsection{SAMPLE ANALYSIS}

This section provides information on the sample exchange processes, chain of custody procedures, and laboratory analytical procedures for the tank farm facility effluent streams covered in this FEMP.

Health Physics personnel use a number of procedures to obtain record and CAM samples from effluent streams, to change-out filters and cartridges, and to deliver specific samples to laboratories for analysis. These procedures reference requirements for accuracy of measurements, methods to preserve samples for counting, sample log and data sheets, and chain of custody procedures. In general, these procedures cover: air sample envelopes; air sample counter log sheets; silver zeolite monitor/cartridge change-out methods; gaseous effluent sampling and monitoring system operability inspection; operation of gaseous effluent sampling and monitoring systems; sampling potentially contaminated water, and beta CAM operational performance tests.

\subsection{EFFLUENT SAMPLE EXCHANGE AND ANALYTICAL LABORATORY PROCEDURES}

This section explains the sample exchange process for the effluent streams from all of the ventilated tanks, the analysis instructions given to the 222-S Laboratory, what happens to the analysis results, and, in general, what happens to the samples at the laboratories.

\subsubsection{Airborne Effuent Sample Exchange Process}

The facility HP group performs the sample exchanges for the tank farm systems.

9.1.1.1 Exchanging Silver Zeolite Cartridges. A sample exchange procedure for silver zeolite cartridges are exchanged per Westinghouse Hanford Company Health Desk Instruction No. DI33300-18-0; "Gaseous Effluent Sampling," dated March 31, 1994, Richland, Washington.

9.1.1.2 Exchanging Record Sample Filters. Record sample filters are exchanged per WHC-IP-0718, Health Physics Procedures, Section 3.3.2, Rev. 1, "Gaseous Effluent Monitoring System Inspection and Sample Exchange," and Section 3.3.3, Rev. 0, Automated Bar Coding of Air Samples at Hanford (ABCASH) (WHC 1992e).

9.1.1.3 Exchanging CAM Filters. CAM Filters are exchanged per WHC-IP-0718, Section 3.3.2, Rev. 1, Gaseous Effluent Monitoring System Inspection and Sample Exchange (WHC 1994a). 
9.1.1.4 Sample Data Examination and Delivery to the 222-S Laboratory. Sample data examination and delivery to the 222-S Laboratory are conducted per WHC-IP-0718, Section 3.3.2, Rev. 1 (WHC 1994a).

9.1.1.5 Laboratory Sample Analysis Instructions. The Effluent Monitoring (EM) group assigns an Effluent Data Processing (EDP) code to each effluent discharge point. This number is used to track the analysis of each effluent stream. The EDP codes for all Tank Farm stacks are listed in Tables 9-1 and 9-2.

Table 9-1. 200 East Tank Farm Effluent Data Processing Codes.

\begin{tabular}{|c|c|c|}
\hline \multicolumn{3}{|c|}{200 East Tank Farms } \\
\hline EDP Code & Stack/facility & Sample \\
\hline E001 & 296-A-22, 242-A Evaporator & AG-1 \\
\hline $\mathrm{E} 002$ & 296-A-22, 242-A Evaporator & AG-2 \\
\hline E013 & 296-A-40, AP Farm & RS \\
\hline $\mathrm{E} 015$ & 296-A-41, AP Annulus & RS \\
\hline E026 & 296-A-17, AY/AZ & AG-1 \\
\hline $\mathrm{E} 027$ & 296-A-17, AY/AZ & AG-2 \\
\hline $\mathrm{E} 052$ & 296-A-13, 244-AR Canyon & $\mathbf{R S}$ \\
\hline E058 & 296-A-12, 244-AR Vessel & RS \\
\hline E059 & 296-A-17, AY/AZ & $\mathbf{R S}$ \\
\hline E060 & 296-A-18, 101-AY Annulus & RS \\
\hline E061 & 296-A-19, 102-AY Annulus & RS \\
\hline E068 & 296-P-16, 105/106-C Tanks & $\mathbf{R S}$ \\
\hline E069 & $296-C-5,244-C R$ & $\mathbf{R S}$ \\
\hline E080 & $296-A-25,244-A$ & RS \\
\hline E120 & $296-\mathrm{P}-17,105-\mathrm{A}$ & RS \\
\hline E197 & 296-A-20, AZ Annulus & $\mathbf{R S}$ \\
\hline E209 & 296-P-31, 209-E Building & RS \\
\hline $\mathrm{E} 270$ & 296-A-27, AW Farm & RS \\
\hline $\mathrm{E} 272$ & 296-A-28, AW Annulus & RS \\
\hline
\end{tabular}


WHC-EP-0479-1

Table 9-1. 200 East Tank Farm Effluent Data Processing Codes.

\begin{tabular}{|c|c|c|}
\hline \multicolumn{3}{|c|}{200 East Tank Farms } \\
\hline EDP Code & Stack/facility & Sample \\
\hline E297 & 296-A-26, 204-AR & $\mathbf{R S}$ \\
\hline E643 & 296-A-22, 242-A Evaporator vessel & RS \\
\hline E645 & 296-A-21, 242-A Evaporator building & $\mathbf{R S}$ \\
\hline E886 & 296-B-28, 244-BX & RS \\
\hline E901 & 296-A-29, AN Farm & RS \\
\hline $\mathrm{E} 903$ & 296-A-30, AN Annulus & RS \\
\hline E933 & 296-A-27, AW Farm & AG-1 \\
\hline E934 & 296-A-27, AW Farm & AG-2 \\
\hline$* * * *$ & 296-A-17, AY/AZ Farm & H3-1 \\
\hline$* * * *$ & 296-P-26, AY/AZ Farm backup & H3-1 \\
\hline$* * * *$ & 296-A-27, AW Farm & H3-1 \\
\hline$* * * *$ & 296-A-29, AN Farm & H3-1 \\
\hline$* * * *$ & 296-A-40, AP Farm & H3-1 \\
\hline$* * * *$ & 296-P-26, AY/AZ Farm backup & RS \\
\hline$* * * *$ & 296-P-26, AY/AZ Farm backup & AG-1 \\
\hline$* * * *$ & 296-P-26, AY/AZ Farm backup & AG-2 \\
\hline $\begin{array}{l}\text { E301- } \\
\text { E399 }\end{array}$ & 296-P-32, Core sampling truck & $\mathbf{R S}$ \\
\hline
\end{tabular}

***** Not assigned or not available

AG - Silver zeolite sample

H3 - Tritium sample

RS - Record sample 
Table 9-2. 200 West Tank Farm Effluent Data Processing Codes.

\begin{tabular}{|l|l|c|}
\hline \multicolumn{3}{|c|}{ 200 West Tank Farms } \\
\hline EDP Code & \multicolumn{1}{|c|}{ Stack/facility } & Sample type \\
\hline W096 & 296-S-18, 242-S Evap. & RS \\
\hline W111 & 296-S-15, SX Farm & RS \\
\hline W117 & 296-T-17, 242-T Evap. & RS \\
\hline W190 & 296-P-23, SY Farm & RS \\
\hline W191 & 296-P-22, SY Annulus & RS \\
\hline W880 & 296-S-22, 244-S & RS \\
\hline W882 & 296-T-18, 244-TX & RS \\
\hline W195 & 296-P-28, SY Farm backup & RS \\
\hline W884 & 296-U-11, 244-U & RS \\
\hline W301- & 296-P-32, Core sampling truck & RS \\
W399 & & \\
\hline
\end{tabular}

RS - Record sample

The Tank Farm sample and analytical requirements for effluent sources are identified annually by EM. Gross alpha and gross beta/gamma analysis is required for all samples. For FY95, the analytical requirements for specific radionuclides are listed in WHC Internal Memo No. 88420-94-130, Analytical Requirements for Effluent Sampling CY 95," dated November 7, 1994, from L. P. Diediker to E. J. Kosiancic (Diediker 1994).

The minimum detectable activities for specific radionuclides are listed in Table 9-3. Note that ${ }^{239,240} \mathrm{Pu},{ }^{241} \mathrm{Am}$, and ${ }^{90} \mathrm{Sr}$ are analyzed quarterly rather than annually. To determine the minimum quantifiable activity for these samples, multiply the values listed in Table 9-3 by 13 weeks/quarter. 
Table 9-3. Minimum Quantifiable Activities for Specific

Radionuclides as Measured in Air Samples Changed Weekly*.

\begin{tabular}{|c|c|c|}
\hline Radionuclide & $\begin{array}{c}\text { Minimum } \\
\text { quantifiable } \\
\text { activity (pCi) }\end{array}$ & $\begin{array}{c}\text { Minimum } \\
\text { quantifiable activity } \\
\text { (pCi/cc) }\end{array}$ \\
\hline${ }^{239,240} \mathrm{Pu}$ & 5 & $1.0 \times 10^{-8}$ \\
\hline${ }^{241} \mathrm{Am}$ & 10 & $2.0 \times 10^{-8}$ \\
\hline${ }^{89,90} \mathrm{Sr}$ & 15 & $3.0 \times 10^{-8}$ \\
\hline${ }^{129} \mathrm{I}$ & 90 & $2.0 \times 10^{-6}$ \\
\hline${ }^{131} \mathrm{I}$ & 50 & $1.0 \times 10^{-7}$ \\
\hline${ }^{125} \mathrm{Sb}$ & 500 & $1.0 \times 10^{-6}$ \\
\hline${ }^{113} \mathrm{Sn}$ & 75 & $2.0 \times 10^{-7}$ \\
\hline${ }^{130} \mathrm{Ru}$ & 50 & $1.0 \times 10^{-7}$ \\
\hline${ }^{106} \mathrm{Ru}$ & 500 & $1.0 \times 10^{-6}$ \\
\hline
\end{tabular}

*Data from an internal memo, 28200-91-018, D. A. Dodd to D. G. Carpenter, "Minimum Detectable Concentrations 222-S Laboratory," dated March 27, 1991 (Dodd 1991).

Assumptions: (1) Airflow is $6 \mathrm{E}-2 \mathrm{~m}^{3} / \mathrm{min}\left(2 \mathrm{ft}^{3} / \mathrm{min}\right)$, and samples are changed on a weekly basis; (2) $\mathrm{Pu}, \mathrm{Am}$, and $\mathrm{Sr}$ are measured from particulate filters.

9.1.1.6 Laboratory Analysis. This section provides a brief description of what becomes of the various sample types after they reach the laboratory.

The Record Sample is held in the laboratory for $7 \mathrm{~d}$ to allow the short lived natural occurring radioisotopes to decay. The sample is then counted for alpha and beta readings. These readings are reported to EM and the Health and Safety group responsible for the facility. These samples are then stored. Once per yearly quarter, these samples are gathered, dissolved, and an radio-isotopic analysis is performed. The results of these analyses are reported to EM.

The CAM samples are not treated as record samples unless this is specifically requested. CAM filters from the stacks are managed by the Radiological Control group. 
The silver zeolite samples are analyzed and the results reported the next day to EM. These samples are not retained.

9.1.1.7 Laboratory Procedures. The analytical laboratory procedures are identified in Section 5.0 and Table 5-1 of WHC-EP-0528-1, Quality Assurance Project Plan for Radioactive Airborne Emissions Data Compilation and Reporting (WHC 1994d).

\subsubsection{Liquid Effluent Samples and Analyses}

Normal facility operations were examined to identify processes performed. The various hazardous materials involved in the processes were identified and the potential for their incorporation into a liquid effluent stream was evaluated. Based on this evaluation, the potential normal components of the liquid effluent stream were identified.

Potential upsets were identified to ensure that the sample analyses would also provide the necessary data for releases under other than normal operations. The hazardous materials that could be introduced into the liquid effluent streams of the facility as a result of such upsets were then identified.

The potential constituents of each liquid effluent stream resulting from both normal operations and upset conditions were examined to determine the possible quantities that could be introduced into the liquid effluent stream. These were examined in relation to analysis detection limits and regulatory release limits. Based on this, the potential liquid effluent constituents requiring analyses were identified. In those cases where past and/or current data were available on liquid effluent sample analyses, these results were examined. Those hazardous material constituents identified at levels above minimum detection limits were incorporated into the list of necessary analytical processes. The need for specific analysis was eliminated if previous or current analyses indicated levels below minimum detection limits, and if no potential upset condition could result in increased levels of the hazardous material. Based on the results, the appropriate analytical method for each remaining hazardous material constituent was determined and the resulting analysis and procedure list was prepared.

Little liquid effluent is generated from current operations at the Tank Farm facilities. However, the possible hazardous constituents that could be introduced to the effluents mandate sampling and analyses.

Liquid effluents from normal operations and the potential upset were reviewed. The active ventilation-process condensate from the 244-AR Vault and 241-A Tank Farm are the streams 
identified as needing sampling and analyses. The analyses to be performed are specified in the following sampling and analysis plans:

\section{LIOUID EFFLUENT STREAM}

244-AR Vault

241-A Tank Farm
SAMPLING \& ANALYSIS PLAN

WHC-SD-WM-EV-076, Rev. 2, 244-AR Vault Cooling Water Sampling and Analysis Plan (WHC 1992a)

WHC-SD-WM-EV-077, Rev. 2, 241-A Tank Farm Cooling Water Sampling and Analysis Plan (WHC 1992b)

\subsection{SAMPLING AND DATA CHAIN OF CUSTODY}

Chain of custody procedures are specified in WHC-IP-0718, procedure number 3.3.2, Rev. 1 (WHC 1994a).

\subsection{U.S. DEPARTMENT OF ENERGY ANALYTICAL AND LABORATORY GUIDELINES}

The analytical and laboratory procedures for the FEMP activities are identified in Section 8.0 of Quality Assurance Project Plan for Facility Effluent Monitoring Plan Activities (WHC 1994b). General requirements for laboratory procedures, data analyses, and statistical treatment are addressed in the Quality Assurance Project Plan (QAPjP). Detailed descriptions of these requirements are given in each FEMP.

The following elements identified in "Environmental Regulatory Guide for Radiological Effluent Monitoring and Environmental Surveillance," DOE/EH-0173T (DOE 1991) are addressed in Quality Assurance Program Plan for Laboratory Analysis and Process Testing, WHC-SD-CP-QAPP-003, Rev. 1 (WHC 1994h), and Quality Assurance Project Plan for Chemical Analysis of Highly Radioactive Mixed Waste Samples in Support of Environmental Activities on the Hanford Site, WHC-SD-CP-QAPP-002, Rev. OA (WHC 1993b).

- Procedures preventing cross contamination

- Documentation of methods

- Gamma emitting radionuclides

- Calibration

- Handling of samples 
- Analysis method and capabilities

- Gross alpha, beta, and gamma measurements

- Direct gamma-ray spectrometry

- Beta counters

- Alpha-energy analysis

- Radiochemical separation procedures

- Reporting of results

- Counter calibration

- Inter calibration of equipment and procedures

- Counter background

- Quality assurance. 
Table 9-4. Data Analyses and Statistical Treatment.

\begin{tabular}{|l|l|}
\hline \multicolumn{1}{|c|}{ Element } & \multicolumn{1}{|c|}{ Documentation } \\
\hline $\begin{array}{l}\text { Summary of data and statistical } \\
\text { treatment requirements }\end{array}$ & WHC-SD-CP-QAPP-003, Rev. 1 (WHC 1994h) \\
\hline $\begin{array}{l}\text { Variability of effluent and } \\
\text { environmental data }\end{array}$ & $\begin{array}{l}\text { WHC-EP-0527-3 Environmental Releases for } \\
\text { Calendar Year 1993 (WHC 1994k) }\end{array}$ \\
\hline $\begin{array}{l}\text { Summarization of data and } \\
\text { testing for outliners }\end{array}$ & $\begin{array}{l}\text { Statistical identification of control standards are } \\
\text { performed by the Laboratory Measurement Control } \\
\text { System (LMCS) data base program during the annual } \\
\text { review of data for setting control limits. Outliners } \\
\text { are evaluated. }\end{array}$ \\
\hline Treatment of significant figures & WHC-SD-CP-QAPP-003, Rev. 1 (WHC 1994h) \\
\hline $\begin{array}{l}\text { Parent-decay product } \\
\text { relationships }\end{array}$ & $\begin{array}{l}\text { Parent-decay product relationships are not accounted } \\
\text { for in laboratory operating procedures. }\end{array}$ \\
\hline $\begin{array}{l}\text { Comparisons to regulatory or } \\
\text { administrative control standards } \\
\text { and control data }\end{array}$ & $\begin{array}{l}\text { The 222-S Laboratory participates in the EPA Intra } \\
\text { Comparison Program }\end{array}$ \\
\hline Quality assurance & $\begin{array}{l}\text { WHC-SD-CP-QAPP-003, Rev. 1 (WHC 1994h) } \\
\text { WHC-SD-CP-QAPP-002, Rev. 0A (WHC 1993b) }\end{array}$ \\
\hline
\end{tabular}


WHC-EP-0479-1

This page intentionally left blank. 


\subsection{NOTIFICATION AND REPORTING REQUIREMENTS}

Notification and reporting requirements are imposed by federal and state law as well as by DOE orders. Because DOE and EPA documents are periodically updated, the current requirements should be obtained from the latest CFR and DOE order. This section is to serve as a guideline for general notification and reporting requirements and as a reference to the sources where specific information may be found for federal, state, and DOE requirements.

\subsection{OCCURRENCE CATEGORIZATION, NOTIFICATION, AND REPORTING}

Notifications and reporting of specific events related to environmental releases and/or events involving effluents and/or hazardous materials shall be made in accordance with DOE Orders 5400.1 (DOE 1990a) and 5000.3B (DOE 1993b). Implementing the orders is accomplished via Management Requirements and Procedures Manual. Specific implementation, where required, is included in the appropriate facility's "Occurrence Categorization, Notification, and Reporting" procedure. Implementing environmental limits and requirements is found in the Environmental Compliance Manual, WHC-CM-7-5.

\subsubsection{Occurrence Identification and Immediate Response}

Each employee shall identify events and conditions and shall promptly notify management of such occurrences.

1. Call 911 if immediate help such as fire, ambulance, or patrol is required.

2. Call 373-3800 (the Patrol Operations Center) if assistance other than fire, ambulance, or patrol is required.

3. After requesting necessary outside assistance, the employee shall notify his or her supervisor, who shall notify the facility manager, the building emergency director, and the Occurrence Notification Center (376-2900).

Operations personnel shall take appropriate immediate action to stabilize or return the facility/operation to a safe condition. Actions taken in response to nonroutine releases, as evidenced by high sample results from liquid and gaseous effluent sampling, are documented in PUREX/UO $\mathrm{O}_{3}$ Plant Administration, WHC-CM-5-9.

The oversight organizations shall notify their DOE Field Office, Richland, counterparts of the event after receiving notifications from, and discussing the event with, the facility manager. 


\subsubsection{Occurrence Categorization}

Occurrences (environmental) shall be categorized as soon as practical using the specific criteria listed in Section 10.2 for radioactive and hazardous materials release. These categorizations should be made within 2 hours of identification. Occurrences shall be categorized by their seriousness; if categorization is not clear, the occurrence shall be categorized initially at the higher level being considered. The occurrence categorization shall then be either evaluated, maintained, or lowered as information becomes available.

\subsection{OCCURRENCE CATEGORIZATION}

The following criteria for categorization of occurrences are established in WHC-CM-1-3, Identifying and Resolving Unreviewed Safety Questions, which implements the requirements contained in DOE Order 5000.3B (DOE 1993b).

\subsubsection{Radioactive Releases}

\subsubsection{Emergency.}

- Any release of radionuclide material to controlled or uncontrolled areas in concentration which, if averaged over 24-hour period, would exceed 5 times the respective reportable quantities specified for such materials in 40 CFR 302.

Note: This event must also meet the criteria for classified emergency in accordance with WHC-CM-4-1, Emergency Plan, and/or facility specific emergency action levels.

\subsubsection{Unusual Occurrence.}

- Release of a radionuclide material that exceeds a federally permitted release by the amount of a CERCLA reportable quantity or, where no federally permitted release exists, the release exceeds the reportable quantity.

- Release of radionuclide material that violates environmental requirements in federal permits, federal regulations, or DOE standards.

- Release below emergency levels which requires immediate (less than 4 hours) reporting to Federal regulatory authorities or triggers specific action levels for an outside agency. 


\subsubsection{Off-Normal.}

- Any release of radionuclide material to controlled or uncontrolled areas that is not part of a normal monitored release and exceeds 50 percent of a CERCLA reportable quantity specified for such material in accordance with 40 CFR 302.

- Any controlled release of radionuclide material that occurs as a monitored part of normal operations which exceeds what historical data and/or analysis show is expected as a result of normal operations.

- Any monitored facility or site boundary where exposure of concentrations exceed what historical data and/or analysis show is expected as a result of normal operations.

- Any detection of a radionuclide in a sanitary or storm sewer, waste or process stream, or any holding points where such a material is not expected.

- Any controlled, uncontrolled, or accidental release which is not classified as an unusual occurrence but which will be reported in writing to state/local agencies in a format other than routine monthly or quarterly reports.

Note: This does not include routine offsite distribution of notification reports.

\subsubsection{Release of Hazardous Substances/Regulated Pollutants/Oil}

\subsubsection{Emergency.}

- Any actual or potential release of material to the environment that results in, or could result in, significant off-site consequences (e.g., need to relocate people, major wildlife kills, major wetland degradation, major aquifer contamination, need to secure downstream water supply intakes, etc.).

Note: This event must also meet the criteria for classified emergency in accordance with WHC-CM-4-1, and/or facility specific emergency action levels.

- Any release of hazardous substances or regulated pollutants in concentrations which exceed 5 times the respective reportable quantities specified for such materials in 40 CFR 302.

Note: This event must also meet the criteria for classified emergency in accordance with WHC-CM-4-1, and/or facility specific emergency action levels. 


\subsubsection{Unusual Occurrence.}

- Release of a hazardous substance or regulated pollutant that exceeds a CERCLA reportable quantity in accordance with 40 CFR 302 or exceeds a federally permitted release by a reportable quantity.

- Release of a hazardous substance, regulated pollutant, or oil that violates environmental requirements in federal permits, federal regulations, or DOE standards.

- Release below emergency levels that requires immediate (less that 4 hours) reporting to federal regulatory agencies or triggers specific levels for an outside federal agency.

- Any release of 100 gallons or more of oil.

\subsubsection{Off-Normal.}

- Release of a hazardous substance or regulated pollutant to controlled or uncontrolled areas that is not part of a normal, monitored release and exceeds 50 percent of a CERCLA reportable quantity as specified for such material in accordance with 40 CFR 302.

- Any release of oil less than unusual occurrence levels but greater than 10 gallons.

- Any detection of a toxic or hazardous substance in a sanitary or storm sewer, waste or process stream, or any holding points where such a material is not expected.

- Any controlled, uncontrolled, or accidental release which is not classified as an unusual occurrence but which will be reported in writing to state/local agencies in a format other than routine monthly or quarterly reports.

Note: This does not include routine offsite distribution of notification reports.

- Any controlled release of hazardous/regulated material that occurs as a monitored part of normal operations which exceeds what historical data and/or analysis shows is expected as a result of normal operations.

- Any general environmental monitoring where concentration increases to a level which exceeds what historical data and/or analysis shows is expected as a result of normal operations. 


\subsubsection{Discovery of Hazardous Material Contamination Due to DOE Operations}

\subsubsection{Emergency.}

- Discovery of contamination that results or could result in significant consequences (i.e. exceeding safe exposure limits to workers or public).

Note: This event must also meet the criteria for classified emergency in accordance with WHC-CM-4-1 and/or facility specific emergency action levels.

- Discovery of onsite or offsite hazardous material contamination in concentrations that exceed 5 times the respective reportable quantities specified for such materials in 40 CFR 302.

Note: This event must also meet the criteria for classified emergency in accordance with WHC-CM-4-1 and/or facility specific emergency action levels.

\subsubsection{Unusual Occurrence.}

- Discovery of on-site or off-site contamination due to DOE operations which does not represent an immediate threat to the public, that exceeds a reportable quantity for such materials in accordance with 40 CFR 302.

- Any discovery of groundwater contamination that is not part of an existing plume previously identified either in an annual report or in any CERCLA/RCRA activity or report.

\subsubsection{Off-Normal.}

- Discovery of onsite contamination attributable to DOE operations that exceeds 50 percent of a reportable quantity for such material in accordance with 40 CFR 302.

\subsubsection{Agreement/Compliance Activities}

\subsubsection{Unusual Occurrence.}

- Any agreement, compliance, remediation, or permit-mandated activity for which formal notification has been received from the relevant regulatory agency that a site plan is not satisfactory, or that a site is considered to be in noncompliance with schedules or requirements.

Note: Formal notification must be received by WHC in writing. 
- Any occurrence under any agreement or compliance area that requires notification of an outside regulatory agency within 4 hours or less, or triggers an outside regulatory agency action level, or otherwise indicates specific interest/concern from such agencies.

Note: This does not include notifications made for radionuclide/hazardous material releases that are less than 50 percent of the reportable quantity as specified in 40 CFR 302.

\subsubsection{Off-Normal.}

- Any occurrence under any agreement or compliance area that will be reported in writing to outside agencies in a format other than routine monthly or quarterly reports.

Note: This does not include routine offsite distribution of notification reports.

\subsubsection{Ecological Resources}

\subsubsection{Unusual Occurrence.}

- Any occurrence causing significant impact to any ecological resource for which the DOE is a trustee (i.e. destruction of a critical habitat, damage to an historical/archeological site, or damage to wetlands).

\subsection{FEDERAL REQUIREMENTS}

\subsubsection{Resource Conservation and Recovery Act of 1976}

The RCRA requires biennial reports to be submitted to the regional administrator of EPA. 40 CFR 262, Subpart D, sets forth the reporting requirements for generators of hazardous waste that ship waste offsite, or store, treat, or dispose of hazardous waste onsite.

Owners or operators of treatment, storage, or disposal (TSD) facilities must comply with the reporting requirements contained in 40 CFR 264, Subpart E and 40 CFR 265, Subpart E.

\subsubsection{Comprehensive Environmental Response, Compensation and Liability Act of 1980}

40 CFR 302 contains reportable quantities and notification requirements for releases of hazardous substances as designated by CERCLA and the Safe Drinking Water Act of 1974. 


\subsubsection{National Emission Standards for Hazardous Air Pollutants}

Compliance and reporting requirements for DOE facilities emitting radionuclides other than radon are contained in 40 CFR 61, Subpart H. The NESHAP requires that an annual report be submitted to EPA headquarters and the appropriate regional office.

\subsection{STATE REQUIREMENTS}

\subsubsection{Generator Reporting}

Generator reporting requirements are found in WAC 173-303-220. The State requires that annual reports covering the preceding year be submitted by March 1 to Ecology.

\subsubsection{Facility Reporting}

Owners or operators of TSD facilities are also required to prepare and submit annual reports. These must be submitted by March 1 and cover facility activities for the previous year. The specific content requirements are specified in WAC 173-303-390.

Effluents produced by PUREX while in transition to shutdown do not contain hazardous or dangerous wastes; therefore, PUREX operations are not subject to RCRA or WAC 173 reporting requirements. WHC would only have to comply with the above federal and state reporting requirements in the event that the facility operations were to change, and discharges (either liquid or gaseous) from the PUREX facility contained a hazardous or dangerous components.

\subsection{U.S. DEPARTMENT OF ENERGY REQUIREMENTS}

\subsubsection{U.S. Department of Energy Order 5400.1, Chapter II General Environmental Protection Program - Notification and Reports}

Consistent with the notification requirements contained in DOE Orders 5484.1 (DOE 1990b), 5000.3B (DOE 1993b) and the DOE 5500 series, field organizations shall notify the Emergency Operations Center (EOC) of the significant nonroutine releases of any pollutant or hazardous substance. 
All DOE facilities that conduct significant environmental protection programs shall prepare an annual site environmental report. Annual summary reports on environmental occurrences shall be included in the annual site environmental report. Suggested content and format for the annual site environmental report are contained in DOE Order 5400.1 (DOE 1990a).

The DOE Order 5400.1 also requires that a radioactive effluent and onsite discharge data report, covering the previous calendar year be submitted to the Waste Information Systems Branch, EG\&G Idaho, in Idaho Falls, Idaho 83415, by April 1. Unplanned releases of radioactive material in effluents, whether onsite or offsite, shall also be reported. The content and forms to be used for these reports are contained in DOE Order 5400.1, Chapter II.

\subsubsection{U.S. Department of Energy Order 5484.1 Environmental Protection, Safety and Health Protection Information Reporting Requirements}

Annual radiation exposure reports for the preceding calendar year are required to be submitted to the System Safety Development Center by March 31. Content and form requirements are in Chapter IV of this order.

The DOE Order 5484.1 also requires radiation exposures of individuals that exceed the specified limits in one calendar quarter to be reported in the form of a memorandum to the Operational and Environmental Safety Division. Radiation exposure limits are listed in Chapter II of this order.

Events that occur in the facility and adversely affect operations, personnel safety, or DOE requirements should receive a thorough investigation and an investigation report should be prepared. DOE Order 5484.1 (DOE 1990b) sets forth occurrences requiring investigation as well as the investigation requirements as determined by the severity of the occurrence, investigation report format, and content outlines.

The RL Order 5484.1 contains the following requirements for the implementation of DOE Order 5484.1 at the Hanford Site. Contractors shall, at a minimum, make oral notification to the appropriate RL program division or office, to the Public Affairs Office (PAO), and to Safety and Quality Assurance (SQA) or the SQA duty officer as soon as it is apparent that an incident may meet the criteria of a Type A or Type B occurrence. A listing of occurrences requiring a Type A or Type B investigation is contained in Chapter I of DOE Order 5484.1. 
Contractors are required to verbally notify responsible SQA environmental protection officials within 24 hours of becoming aware of any of the following occurrences:

- Violation of applicable federal, state, or local pollution control standards and requirements

- Any noncompliance with the terms and/or conditions of an existing NPDES permit, Prevention of Significant Deterioration (PSD) permit, or any other environmental protection based permit or formal agreement with an applicable regulatory body

- Any gaseous or liquid radiological effluent releases which exceed DOE requirements and/or contractor specific radiological release concentration guides.

Following verbal notifications, written reports must be submitted according to procedures in DOE Order 5000.3B (DOE 1993b). 
WHC-EP-0479-1

This page intentionally left blank. 


\subsection{INTERFACE WITH THE OPERATIONAL ENVIRONMENTAL MONITORING PROGRAM}

\subsection{DESCRIPTION}

The sitewide Environmental Monitoring Plan (EMP), as described in Management Plan for the Facility Effluent Monitoring Plan Activities, WHC-EP-0491 (WHC 1991b), consists of two distinct but related components; environmental surveillance conducted by PNL and effluent monitoring conducted by WHC. The responsibilities for these two portions of the EMP are delineated in a Memorandum of Understanding (MOU 1989). Environmental surveillance, conducted by PNL, consists of surveillance of all environmental parameters to demonstrate compliance with regulations. Effluent monitoring includes both in-line and facility effluent monitoring as well as near-field (near-facility) operational environmental monitoring. Projected EDEs, reported in this FEMP, are the products of in-line effluent monitoring. Near-field monitoring is required by WHC-CM-7-5, Environmental Compliance Manual, Section 5.4, "Environmental Monitoring," and procedures described in WHC-CM-7-4, Operational Environmental Monitoring.

\subsection{PURPOSE}

The purpose of the Operational Environmental Monitoring Program (OEMP) is to provide facility-specific environmental monitoring to protect the environment adjacent to facilities under the responsibility of WHC and assure compliance with WHC requirements and local, state, and federal environmental regulations.

The objectives of the OEMP are to evaluate the following:

- Compliance with DOE, EPA, Ecology, WDOH, and internal WHC environmental radiation protection requirements and guides

- Performance of radioactive waste confinement systems

- Trends of radioactive materials in the environment at and adjacent to nuclear facilities and waste disposal sites. 
Specifically, the OEMP is developed to:

- Monitor all inactive, existing, and new low-level waste (LLW) disposal sites to assess both radiological and nonradiological hazards (DOE Order 5820.2A [DOE 1988b]).

- Determine the effectiveness of effluent treatment and controls in reducing effluents and emissions (DOE/EH-0173T, Page 1-1, Par. 1 [DOE 1991b]) (DOE/EV/1830-T5 [DOE 1980]).

- Detect and quantify unplanned releases (DOE/EH-0173T, Page 1-1, Par. 2 [DOE 1991b]) (40 CFR 302) (WAC 173-303-145) (DOE 5000.3A [DOE 1993b]) (DOE Order 5484.1 [DOE 1990b]).

- Monitor fugitive emissions and diffuse sources from contaminated areas for compliance with NESHAP (40 CFR 61), DOE/EH-0173T, Pg. 3-4, 3.3.2 (DOE 1991b), Toxic Air Emissions Inventory (40 CFR 265, Subparts AA and B13), State Operating Permit Program (40 CFR 70), and Source Registration (WAC 246-247).

- Monitor all surplus facilities prior to decontaminating or decommissioning (DOE Order 5820.2A [DOE 1988b]).

- Monitor new and existing sites, processes, and facilities for potential impacts and releases (DOE Order 5484.1 [DOE 1990b] and DOE/EH-0173T [DOE 1991b]).

- Monitor and assess radioactive contamination and potential exposure to employees and the public (DOE Orders 5400.1 [DOE 1990a] and 5400.5 [DOE 1990c]).

The purpose and justification for the OEMP is contained in WHC-CM-7-4, Operational Environmental Monitoring, and WHC-CM-7-5, Environmental Compliance. The primary justification for the OEMP include the following:

- The OEMP provides a level of assurance to WHC that the effluent and contamination controls for the various facilities and waste sites are effective.

- The OEMP monitors a diversity of operations, activities, and programs managed by several different WHC organizations. Accordingly, the program direction and integration function performed by Environmental Engineering Studies (EES) is needed to assure program consistency, technical quality, and cost effectiveness.

- A secondary aspect of the OEMP is additional assurance beyond that provided by the Occupational Health and Safety Program that it is "OK" to work onsite and for visitors to safely tour the site. 


\subsection{BASIS}

Near-field environmental surveillance is conducted to (1) monitor employee protection; (2) monitor environmental protection; and (3) ensure compliance with local, State, and Federal regulations. Compliance with parts of the following DOE orders, 40 CFRs, and WACs are addressed through this activity.

- DOE Order 5000.3B, Occurrence Reporting and Processing of Operational Information (DOE 1993b)

- DOE Order 5400.1, General Environmental Protection Program (DOE 1990a)

- DOE Order 5400.5, Radiation Protection of the Public and the Environment (DOE 1990c)

- DOE Order 5484.1, Protection, Safety, and Health Protection Information Reporting System (DOE 1990b)

- DOE Order 5820.2A, Radioactive Waste Management (DOE 1988b)

- DOE/EH-0173T, Environmental Regulatory Guide for Radiological Effluent Monitoring and Environmental Surveillance (DOE 1991b)

- DOE/EV/1830-T5, Guide to Reducing Radiation Exposure to As Low As Reasonably Achievable, 1980 (DOE 1980)

- 40 CFR 61, "National Emission Standards for Hazardous Air Pollutants"

- 40 CFR 70, "State Operating Permit Programs"

- 40 CFR 265, Subpart AA and B13, "Interim Status Standards for Owners and Operators of Hazardous Waste Treatment, Storage, and Disposal Facilities"

- 40 CFR 302, "Designation, Reportable Quantities, and Notification"

- WAC 173-303-145, "Dangerous Waste Regulations (Spills and Discharges)"

- WAC 246-247, "Radiation Protection - Air Emissions"

\subsection{MEDIA SAMPLED AND ANALYSES PERFORMED}

Procedure protocols for sampling, analysis, data handling, and reporting are specified in WHC-SD-CP-QAPP-002 (WHC 1993b). Media include ambient air, surface water, groundwater, external radiation dose, soil, sediment, vegetation, and animals at or near 
active and inactive facilities and/or waste sites. Parameters monitored include the following, as needed: $\mathrm{pH}$, water temperature, radionuclides, radiation exposure, and hazardous constituents. Animals that are not contaminated, as determined by a field instrument survey, are released to a nonhazardous environment.

\subsection{LOCATIONS}

Samples are collected from known or suspected effluent pathways (e.g., downwind of potential releases, liquid streams, or proximal to release points). To avoid duplication, WHC relies on existing sample locations where PNL has previously established sample sites (e.g., air samplers in the 300 Area). There are 38 air samplers (4 in the 100 Area and 34 in the 200/600 Areas), 35 surface water sample sites (22 in the 100 Area and 13 in the $200 / 600$ Areas), 110 groundwater monitoring wells (20 in the 100 Area, 89 in the 200/600 Areas, and 1 in the 300/400 Areas), 299 external radiation monitor points (182 survey points and 41 thermoluminescent dosimeter (TLD) sites in the 100 Area, 61 TLD sites in the 200/600 Areas, and 15 TLD sites in the 300/400 Areas), 157 soil sample sites (32 in the 100 Area, 110 in the 200/600 Areas, and 15 in the 300/400 Areas), and 95 vegetation sample sites (40 in the 100 Area, 40 in the 200/600 Areas, and 15 in the $300 / 400$ Areas). Animal samples are collected at or near facilities and/or waste sites. Specific locations of sample sites are found in WHC-CM-7-4.

Surveys to detect surface radiological contamination, scheduled in WHC-SP-0098-5 (WHC 1993c), are conducted near and on liquid waste disposal sites (e.g., cribs, trenches, drains, retention basin perimeters, pond perimeters, and ditch banks), solid waste disposal sites (e.g., burial grounds and trenches), unplanned release sites, tank farm perimeters, stabilized waste disposal sites, roads, and firebreaks in the Operations Areas. There are 391 sites in the Operations Areas (100 in the 100 Area, 273 in the 200/600 Areas, and 18 in the 300/400 Areas) where radiological surveys are conducted.

\subsection{PROGRAM REVIEW}

The near-field (operational environmental) monitoring program will be reviewed at least annually to determine that the appropriate effluents are being monitored and that the monitor locations are in position to best determine potential releases.

\subsection{SAMPLER DESIGN}

Sampler design (e.g., air monitors) will be reviewed at least biannually to determine equipment efficiency and compliance with current EPA and industry (e.g., ANSI and American Society for Testing and Materials [ASTM]) standards. 


\subsection{COMMUNICATION}

The operations and engineering contractor and the research and development contractor will compare and communicate results of their respective monitoring programs at least quarterly and as soon as possible under upset conditions.

\subsection{REPORTS}

Results of the near-field operational environmental monitoring program are published in: Environmental Releases for Calendar Year 1993, WHC-EP-0527-3 (WHC 1994c) and WHC Operational Environmental Monitoring Annual Report, Calendar Year 1993, WHC-EP-0573-2 (WHC 1994L). The radionuclide values in these reports are expressed in curies, or portions thereof, for each radionuclide per unit weight of sample (e.g., picocuries per gram) or in field instrument values (e.g., counts per minute). Values are reported in this manner, rather than EDE, which is calculated as the summation of the products of the dose equivalent received by specified tissues of the body and a tissue-specific weighting factor. 
WHC-EP-0479-1

This page intentionally left blank. 


\subsection{QUALITY ASSURANCE}

\subsection{PURPOSE}

This Quality Assurance (QA) Plan describes the quality assurance requirements associated with implementing FEMPs. The plan identifies the FEMP activities and assigns the appropriate quality assurance requirements defined by the Quality Assurance Manual, WHC-CM-4-2. This Quality Assurance Plan shall be consistent with the requirements in DOE Order 5700.6C, Quality Assurance (DOE 1991a). In addition, quality assurance requirements in 40 CFR 60 , "Reference Methodologies," shall be considered when performing monitoring calculations and establishing monitoring systems.

A QA plan is required for facilities meeting the criteria for FEMP preparation and implementation. 40 CFR 61.93 (b)(2)(iv) states that a quality assurance program shall be conducted that meets the performance requirements described in Appendix B, Method 114 of 40 CFR 61.

\subsection{OBJECTIVE}

The objective of this chapter is to provide a documented plan describing QA requirements specific to Tank Farms.

\subsection{REQUIREMENTS}

WHC-EP-0446-2, Quality Assurance Plan For Facility Effluent Monitoring Plan Activities (WHC 1994b), was written to specify all QA requirements that apply to field activities, laboratory analyses, and continuous monitoring performed for all FEMPs conducted by Westinghouse Hanford. The requirements of this referenced Quality Assurance Project Plan (QAPP) shall be considered in preparing each FEMP.

Organizations that support the tank farms must follow current approved procedures to comply with requirements of the plan. Ongoing review and modification of the functional procedures will assure full compliance with the requirements of the QA manual.

Engineering, Safety, Quality Assurance, and Environmental Protection organizations shall evaluate engineered systems which protect the public, employees, the environment, and/or operations from radiological and hazardous materials. Their evaluations shall identify areas of significant concern requiring the development of QA verification plans. 
Quality Assurance programs shall be developed and implemented to assess the performance of organizations responsible for the QA plan. Verification methods defined in the planning for FEMP activities, including those associated with equipment or component items, shall undergo inspection, surveillance, and audit in any combination that will confirm compliance with designated requirements.

\subsection{FACILITY-SPECIFIC REQUIREMENTS}

The analytes of interest applicable to the tank farms liquid effluent and air emission samples are identified annually by Effluent Monitoring (EM) group. Procedural controls specific to the tank farms are presented in Section 9.0. 


\subsection{INTERNAL AND EXTERNAL PLAN REVIEW}

The General Environmental Protection Program, DOE Order 5400.1, Chapter IV.4 (DOE 1990a), requires the FEMP be reviewed annually and updated every 3 years. The FEMP should be reviewed and updated as necessary after each major change or modification in the facility processes, facility structure, ventilation and liquid collection systems, monitoring equipment, waste treatment, or a significant change to the Safety Analysis Reports. In addition, EPA regulations require that records on the results of radioactive airborne emissions monitoring be maintained on site for 5 years. Operations management shall maintain records of reports on measurements of stack particulates or other nonradioactive hazardous pollutant emissions for three years. Facility operators will have to certify on a semiannual basis that no changes in operations that would require additional measurements have occurred.

Westinghouse Hanford Effluent Monitoring (EM) prepares an annual effluent discharges report for each area on the Hanford Site to cover both airborne and liquid release pathways. Although the report is based on the calendar year, the emission limits apply to any period of 12 consecutive months. In addition, a report on the air emissions and compliance to the Clean Air Act is prepared by EM and submitted to EPA as well as DOE-HQ.

Facility management is to obtain the EM function's approval for all changes to the FEMPs, including those generated in the annual review and update. In addition, the FEMP shall be reviewed by QA. 
WHC-EP-0479-1

This page intentionally left blank. 


\subsection{COMPLIANCE ASSESSMENT}

The purpose of this section is to assess the compliance status of the effluent sampling and monitoring systems described in Section 7.0, with the applicable regulations listed in Section 3.0. The Designated NESHAP stacks are as follows:

Stack

296-A-17

296-P-26

296-A-22

296-A-25

296-A-27

296-A-29

296-A-40

296-B-28

296-C-5

296-P-16

296-P-23

296-P-28

296-S-15

296-S-22

296-T-18

296-U-11
Facility

241-AY/AZ Tank Farm Exhauster

241-AY/AZ Tank Farm Backup Exhauster

242-A Evaporator Vessel Vent

244-A Double Contained Receiver Tank Exhauster

241-AW Tank Farm Exhauster

241-AN Tank Farm Exhauster

241-AP Tank Farm Exhauster

244-BX Double Contained Receiver Tank Exhauster

244-CR Vault Exhauster

241-C-105/106 Tank Exhauster

241-SY Tank Farm Exhauster

241-SY Tank Farm Backup Exhauster

241-SX Tank Farm Exhauster

244-S Double Contained Receiver Tank Exhauster

244-TX Double Contained Receiver Tank Exhauster

244-U Double Contained Receiver Tank Exhauster

A comparison with the requirements of 40 CFR 61.93 was prepared for each of the designated stacks (with the exception of 244-U, which was recently upgraded and is in compliance with 40 CFR 61.93). The comparisons identify existing conditions which may need to be corrected to achieve compliance with 40 CFR 61.93. The comparisons are located in the following documents:

$\begin{array}{ll}\text { STACK } & \text { COMPLIANCE ASSESSMENT DOCUMENT } \\ 296-A-22 & \text { WHC-EP-0542 } \\ 296-A-40 & \text { WHC-EP-0543 } \\ 296-A-17 & \text { WHC-EP-0784 } \\ 296-P-26 & \text { WHC-EP-0784 } \\ 296-A-25 & \text { WHC-EP-0784 } \\ 296-A-27 & \text { WHC-EP-0784 } \\ 296-A-29 & \text { WHC-EP-0784 } \\ 296-B-28 & \text { WHC-EP-0784 } \\ 296-C-5 & \text { WHC-EP-0784 } \\ 296-P-16 & \text { WHC-EP-0784 } \\ 296-P-23 & \text { WHC-EP-0784 }\end{array}$


296-P-28

296-S-15

296-S-22

296-S-22

296-T-17

296-T-18
WHC-EP-0784

WHC-EP-0784

WHC-EP-0784

WHC-EP-0784

WHC-EP-0784

WHC-EP-0784

\subsection{COMPLIANCE ASSESSMENT}

This section of the FEMP summarizes deficiencies identified by the point-by-point comparisons. The deficiencies have been grouped under the following categories; flow measurement, specific radionuclide analysis, and sample probe.

\subsubsection{The 296-A-22 Stack (242-A Evaporator Vessel Vent)}

The deficiencies noted in the point-by-point comparison for the evaporator (WHC-EP-0542 [Crummel et al. 1992]) have been corrected to the satisfaction of the Environmental Protection Agency (EPA), which has concurred that this stack is in compliance with the requirements of 40 CFR 61.93 (Poeton 1994a). The detailed compliance assessment is located in WHC-EO-0466-2 (Crummel and Gustavson 1995).

\subsubsection{The 296-A-40 Stack (AP Tank Farm)}

FLOW MEASUREMENT

- Less than 16 measurements are taken along each traverse.

- Flow location does not meet alternate criteria (2 duct diameters upstream $/ 1 / 2$ duct diameter downstream).

- Flow is variable ( $>10 \%)$ - measurements should be taken frequently.

\section{SPECIFIC RADIONUCLIDE ANALYSIS}

- Not accomplished for radionuclides $>10 \%$ of potential EDE.

\subsubsection{The 296-A-17 Stack (AY/AZ Tank Farm Exhauster)}

\section{FLOW MEASUREMENT}

- Measurements are only taken along one traverse (instead of two).

- Flow is variable ( $>10 \%)$ - measurements should be taken frequently. 
WHC-EP-0479-1

14.1.4 The 296-P-26 Stack (AY/AZ Tank Farm Backup Exhauster)

- None.

\subsubsection{The 296-A-25 Stack (244-A Double Contained Receiver Tank Exhauster)}

FLOW MEASUREMENT

- Measurements are only taken along one traverse (instead of two).

- Flow is variable (>10\%) - measurements should be taken frequently.

- Flow is measured upstream of sample probe location (instead of downstream).

SPECIFIC RADIONUCLIDE ANALYSIS

- Not accomplished for radionuclides $>10 \%$ of potential EDE.

\subsubsection{The 296-A-27 Stack (AW Tank Farm Exhauster)}

FLOW MEASUREMENT

- Flow is variable ( $>10 \%$ ) - measurements should be taken frequently.

- Flow is measured upstream of sample probe location (instead of downstream).

SAMPLE PROBE

- Nozzle length does not meet ANSI N13.1 guidelines.

\subsubsection{The 296-A-29 Stack (AN Tank Farm Exhauster)}

FLOW MEASUREMENT

- Flow is measured upstream of sample probe location (instead of downstream).

SAMPLE PROBE

- Bend radius does not meet ANSI N13.1 guidelines. 


\subsubsection{The 296-B-28 Stack (244-BX Double Contained Receiver Tank Exhauster)}

FLOW MEASUREMENT

- Less than 16 measurements are taken along each traverse.

- Flow is variable (>10\%) - measurements should be taken frequently.

- Flow is measured upstream of sample probe location (instead of downstream).

SPECIFIC RADIONUCLIDE ANALYSIS

- Not accomplished for radionuclides $>10 \%$ of potential EDE.

\subsubsection{The 296-C-5 Stack (244-CR Vault Exhauster)}

FLOW MEASUREMENT

- Flow is variable ( $>10 \%)$ - measurements should be taken frequently.

- Flow is measured upstream of sample probe location (instead of downstream).

SAMPLE PROBE

- Probe should have 3 nozzles.

SPECIFIC RADIONUCLIDE ANALYSIS

- Not accomplished for radionuclides $>10 \%$ of potential EDE.

\subsubsection{The 296-P-16 Stack (C-105/106 Tank Exhauster)}

FLOW MEASUREMENT

- Measurements are only taken along one traverse (instead of two).

- Flow is variable (>10\%) - measurements should be taken frequently.

SPECIFIC RADIONUCLIDE ANALYSIS

- Not accomplished for radionuclides $>10 \%$ of potential EDE. 


\subsubsection{The 296-P-23 Stack (SY Tank Farm Exhauster)}

\section{FLOW MEASUREMENT}

- Flow is variable ( $>10 \%)$ - measurements should be taken frequently.

- Flow is measured upstream of sample probe location (instead of downstream).

\subsubsection{The 296-P-28 Stack (SY Tank Farm Backup Exhauster)}

\section{FLOW MEASUREMENT}

- Measurements are only taken along one traverse (instead of two).

- Less than 16 measurements are taken along each traverse.

- Flow is variable ( $>10 \%)$ - measurements should be taken frequently.

- Flow is measured upstream of sample probe location (instead of downstream).

\section{SPECIFIC RADIONUCLIDE ANALYSIS}

- Not accomplished for radionuclides $>10 \%$ of potential EDE.

\subsubsection{The 296-S-15 Stack (SX Tank Farm Exhauster)}

\section{FLOW MEASUREMENT}

- Measurements are only taken along one traverse (instead of two).

- Flow location does not meet alternate criteria (2 duct diameters upstream / $1 / 2$ duct diameter downstream).

- Flow is variable ( $>10 \%)$ - measurements should be taken frequently.

\section{SAMPLE PROBE}

- Sample probe location does not meet alternate criteria.

- Nozzle length does not meet ANSI N13.1 guidelines.

\section{SPECIFIC RADIONUCLIDE ANALYSIS}

- Not accomplished for radionuclides $>10 \%$ of potential EDE. 
14.1.14 The 296-S-22 Stack (244-S Double Contained Receiver Tank Exhauster)

FLOW MEASUREMENT

- Measurements are only taken along one traverse (instead of two).

- Less than 16 measurements are taken along each traverse.

- Flow is variable ( $>10 \%)$ - measurements should be taken frequently.

- Flow is measured upstream of sample probe location (instead of downstream).

SAMPLE PROBE

- Bend radius does not meet ANSI N13.1 guidelines.

- Probe length does not meet ANSI N13.1 guidelines.

SPECIFIC RADIONUCLIDE ANALYSIS

- Not accomplished for radionuclides $>10 \%$ of potential EDE.

\subsubsection{The 296-T-18 Stack (244-TX Double Contained Receiver Tank Exhauster)}

FLOW MEASUREMENT

- Less than 16 measurements are taken along each traverse.

- Flow is variable ( $>10 \%)$ - measurements should be taken frequently.

- Flow is measured upstream of sample probe location (instead of downstream).

SPECIFIC RADIONUCLIDE ANALYSIS

- Not accomplished for radionuclides $>10 \%$ of potential EDE.

\subsubsection{The 296-U-11 Stack (244-U Double Contained Receiver Tank Exhauster)}

A point-by-point compliance assessment was not prepared for the 296-U-11 stack because the stack was recently upgraded and is in compliance with 40 CFR 61.93 . 


\subsection{CORRECTIVE ACTIONS REQUIRED FOR COMPLIANCE}

\subsubsection{Discussion of Deficiencies}

The actions required to correct the deficiencies fall into three different categories:

- Administrative

- Minor equipment modification

- Major equipment modification.

Administrative deficiencies are procedural in nature and are currently being corrected.

Minor deficiencies are those that could be corrected by a equipment modification accomplished by existing by craft personnel. An example of a minor equipment modification would be to drill a hole in a stack downstream of the HEPA filters and install a threaded nipple to be used as a flow measurement port.

Some deficiencies listed as minor deficiencies on one stack could be major deficiencies on a different stack due to the differences in stack height, access to the stack (obstructions), etc.

Major deficiencies require extensive equipment modifications that would need to be accomplished by an upgrade project.

A discussion of the deficiencies in each category and corresponding corrective action are described below.

14.2.1.1 Administrative Deficiencies. Administrative corrective actions are being pursued to correct all of the deficiencies that fall into this category. The administrative deficiencies and corrective actions are as follows:

- FLOW MEASUREMENT

- Less than 16 measurements taken along each traverse.

- SPECIFIC RADIONUCLIDE ANALYSIS

- Not accomplished for radionuclides $>10 \%$ of potential EDE.

\section{DISCUSSION:}

New stack flow measurement procedures have been prepared. The new procedures include all of the stack flow measurement requirements (with the exception of number of measurements along each traverse), and are being implemented in CY 95. Because of the impracticality of taking 16 measurements along a traverse in a small stack (for example 8 inches), a waiver from this requirement should be pursued from Environmental Protection Agency, Region X, if appropriate. 
Specific radionuclide analysis was not performed on all of the radionuclides which could contribute greater than 10 percent of the potential offsite dose from a release point. In some cases, the specific analysis may not have been performed for a radionuclide because the radionuclide may not have contributed to greater than 10 percent of the actual offsite dose from a release point. The specific analysis performed in CY 95 and thereafter will include analysis for all radionuclides which contribute to greater than 10 percent of the potential offsite dose.

14.2.1.2 Minor Equipment Modification Deficiencies. Minor deficiencies could be corrected by existing craft personnel. It may also be possible to get a waiver from the Regional EPA Office for minor deficiencies (as indicated by R.W. Poeton, Radiation and Indoor Air Section, EPA Region X, in November 2, 1994 Federal Facility Compliance Agreement [FFCA] update meeting). The minor deficiencies and corrective actions are as follows:

- FLOW MEASUREMENT

- Measurements are only taken along one traverse (instead of two).

- Flow location does not meet alternate criteria (2 duct diameters upstream / $1 / 2$ duct diameter downstream).

- Flow is measured upstream of sample probe location (instead of downstream).

- SAMPLE PROBE

- Probe does not have the proper number of nozzles.

- Bend radius does not meet ANSI N13.1 guidelines.

- Nozzle length does not meet ANSI N13.1 guidelines.

\section{DISCUSSION:}

The EPA has reviewed and responded to the Point-By-Point comparisons, indicating that the designated stacks do not comply with the requirements of 40 CFR 61.93, primarily because of the flow variability ( $>10$ percent) and anisokinetic sampling conditions. Attempting to correct the minor equipment deficiencies or apply for a waiver for the minor equipment deficiencies may not be of any benefit if the major deficiencies can only be corrected by an upgrade project. Since this issue requires further analysis, the approach for addressing the minor deficiencies will be included in the next revision to this FEMP. 
14.2.1.3 Major Equipment Modification Deficiencies. It is not likely that major deficiencies can be corrected by other than an upgrade project. The major deficiencies and corrective actions are as follows:

- FLOW MEASUREMENT

- Flow location does not meet alternate criteria (2 duct diameters upstream / $1 / 2$ duct diameter downstream).

- Flow is variable ( $>10 \%$ ) - measurements should be taken frequently.

- Flow is measured upstream of sample probe location (instead of downstream).

- SAMPLE PROBE

- Probe should have 3 nozzles.

- Bend radius does not meet ANSI N13.1 guidelines.

- Nozzle length does not meet ANSI N13.1 guidelines.

\section{DISCUSSION:}

The EPA has provided DOE-RL with comments on the Point-By-Point comparisons. As required by the FFCA, DOE-RL has 90 days (until March 1, 1995) to provide the EPA with a schedule for correcting the deficiencies. 
WHC-EP-0479-1

This page intentionally left blank. 


\subsection{SUMMARY AND CONCLUSIONS}

\subsection{FEDERAL FACILITY COMPLIANCE AGREEMENT}

On February 7, 1994, the U.S. Department of Energy, Richland Operations Office (RL) and the U.S. Environmental Protection Agency, Region 10 entered into a Federal Facility Compliance Agreement (EPA) concerning:

1. Identification of correct regulatory status (in regards to the NESHAP regulations) of all Hanford Emission points

2. identification of deficiencies in the systems

3. identification of deficiency correction schedules.

Items 1 and 2 have been accomplished. For Tank Farms, the correct regulatory status has been identified in WHC-SD-WM-EMP-031 (WHC 1994m) and the deficiencies have been identified in WHC-EP-0784 (WHC 1994g). Item No. 3 is yet to be negotiated. Provided in Sections 15.2 and $\mathbf{1 5 . 3}$ are summaries of deficiencies and current upgrade/replacement plans.

\subsection{SUMMARY OF CURRENT DEFICIENCIES}

Table 15-1 is a summary of details and deficiencies discussed in Section 14.0. Tables 15-2, 15-3, and 15-4 provide more detail on each deficiency. 
Table 15-1. Summary of Deficiencies.

\begin{tabular}{|c|c|c|c|c|c|c|c|c|c|c|}
\hline Stack & $\begin{array}{c}\text { Flow } \\
\text { procedure }\end{array}$ & $\begin{array}{l}\text { Number of } \\
\text { flow } \\
\text { traverses }\end{array}$ & $\begin{array}{l}\text { Number of } \\
\text { flow } \\
\text { ports }\end{array}$ & $\begin{array}{c}\text { Flow } \\
\text { port } \\
\text { location }\end{array}$ & $\begin{array}{c}\text { Flow } \\
\text { frequency }\end{array}$ & $\begin{array}{c}\text { Probe } \\
\text { location }\end{array}$ & $\begin{array}{l}\text { Probe } \\
\text { design }\end{array}$ & $\begin{array}{l}\text { Collection } \\
\text { efficiency }\end{array}$ & $\begin{array}{l}\text { Specific } \\
\text { analysis }\end{array}$ & $\begin{array}{c}\text { Equivalency } \\
\text { requested }\end{array}$ \\
\hline 296-A-17 & & & $\mathbf{R}$ & & & & & $\mathbf{X}$ & & No \\
\hline $296-P-26$ & & & & & & & & & & Yes \\
\hline $296-A-25$ & & . & & $I$ & $\mathbf{R}$ & & & & $\bar{A}$ & Yes \\
\hline $296-A-27$ & & & & I & $\overline{\mathbf{R}}$ & & I & $\bar{x}$ & & No \\
\hline $296-A-29$ & & & & I & & & I & $\bar{X}$ & & No \\
\hline $296-\mathrm{A}-40$ & & $\mathrm{I}$ & & $I$ & $\mathbf{R}$ & & $\bar{X}$ & & $\bar{A}$ & No \\
\hline $296-B-28$ & & I & & I & $\overline{\mathbf{R}}$ & & & $\bar{X}$ & $\overline{\mathbf{A}}$ & No \\
\hline $296-C-05$ & & & $\mathbf{R}$ & & $\mathbf{R}$ & & I & & $\mathbf{A}$ & Yes \\
\hline 296-P-16 & & & $\mathbf{R}$ & & $\mathbf{R}$ & & & & $\bar{A}$ & Yes \\
\hline $296-P-23$ & & & & I & $\bar{R}$ & & & & & Yes \\
\hline $296-\mathrm{P}-28$ & & I & $\overline{\mathbf{R}}$ & $\bar{I}$ & $\mathbf{R}$ & & & $\bar{X}$ & $\overline{\mathbf{A}}$ & No \\
\hline $296-S-15$ & & & $\mathbf{R}$ & I & $\overline{\mathbf{R}}$ & $\bar{x}$ & I & & $\bar{A}$ & No \\
\hline $296-S-22$ & & I & $\mathbf{R}$ & I & & & $I$ & $\bar{X}$ & $\bar{A}$ & No \\
\hline 296-T-18 & & I & & I & $\mathbf{R}$ & & & $\mathbf{X}$ & $\mathbf{A}$ & No \\
\hline
\end{tabular}

A - Administrative deficiency

I - Insignificant deficiency

$\mathbf{R}$ - Deficiency corrected by recommendation

X - Major deficiency 
This table summarizes emissions, current flow measurement errors resulting from variable flows, and sampling/monitoring collection efficiencies.

Table 15-2. Emissions, Measurement Errors, and Collection Efficiencies.

\begin{tabular}{|c|c|c|c|c|c|}
\hline \multirow[t]{2}{*}{ Stack } & \multicolumn{2}{|c|}{$\begin{array}{l}\text { Emissions } \\
(\mathrm{mrem} / \mathrm{yr})\end{array}$} & \multirow{2}{*}{$\begin{array}{c}\text { Flow } \\
\text { measurement } \\
\text { variability }\end{array}$} & \multicolumn{2}{|c|}{$\begin{array}{c}\text { Collection efficiency } \\
\text { (lowest) }\end{array}$} \\
\hline & Potential & Actual & & $3.5 \mu \mathrm{m}$ & $10 \mu \mathrm{m}$ \\
\hline 296-A-17 & 226 & $1.28 \mathrm{E}-05$ & $18 \%$ & $77.5 \%$ & $1.4 \%$ \\
\hline 296-P-26 & 226 & $1.28 \mathrm{E}-05$ & $7 \%$ & $92.7 \%$ & $57.2 \%$ \\
\hline $296-A-25$ & 0.11 & $7.9 \mathrm{E}-09$ & $21 \%$ & $89.4 \%$ & $49.3 \%$ \\
\hline 296-A-27 & 148 & $4.12 \mathrm{E}-08$ & $24 \%$ & $57.4 \%$ & $0 \%$ \\
\hline 296-A-29 & 846 & $3.68 \mathrm{E}-09$ & $16 \%$ & $58.6 \%$ & $0.2 \%$ \\
\hline $296-A-40$ & 47.4 & $2.0 \mathrm{E}-9$ & & $87.5 \%$ & \\
\hline 296-B-28 & 0.16 & $7.4 \mathrm{E}-09$ & $24 \%$ & $78.8 \%$ & $3.6 \%$ \\
\hline $296-C-05$ & 187 & $3.1 \mathrm{E}-07$ & $91 \%$ & $91.6 \%$ & $52.5 \%$ \\
\hline 296-P-16 & 1.68 & $4.66 \mathrm{E}-07$ & $23 \%$ & $86.6 \%$ & $38.4 \%$ \\
\hline $296-P-23$ & 10.5 & $2.92 \mathrm{E}-08$ & $24 \%$ & $88.4 \%$ & $38.6 \%$ \\
\hline 296-P-28 & 10.5 & $2.92 \mathrm{E}-08$ & $29 \%$ & $83.9 \%$ & $17.7 \%$ \\
\hline $296-S-15$ & 270 & $2.17 \mathrm{E}-09$ & $55 \%$ & $92.3 \%$ & $48.6 \%$ \\
\hline $296-S-22$ & 0.34 & 7.7E-08 & $18 \%$ & $78.7 \%$ & $9.2 \%$ \\
\hline 296-T-18 & 0.18 & $1.54 \mathrm{E}-08$ & $39 \%$ & $76.9 \%$ & $8.8 \%$ \\
\hline
\end{tabular}


This table provides details on comparison of the current flow measurement practice as compared to the regulatory directed method.

Table 15-3. Flow Measurement.

\begin{tabular}{|c|c|c|c|c|c|c|}
\hline Stack & Procedure & $\begin{array}{c}\text { Number } \\
\text { of } \\
\text { Traverse } \\
\text { Points }\end{array}$ & $\begin{array}{l}\text { Number } \\
\text { of Ports }\end{array}$ & $\begin{array}{c}\text { Port } \\
\text { Location }\end{array}$ & $\begin{array}{l}\text { Location } \\
\text { Error }\end{array}$ & $\begin{array}{c}\text { Frequency } \\
\text { (based on 20\%) }\end{array}$ \\
\hline $296-A-17$ & ok & ok & one & ok & NA & ok \\
\hline 296-P-26 & $\overline{\text { ok }}$ & ok & $\overline{\text { ok }}$ & ok & $\overline{\mathrm{NA}}$ & ok \\
\hline $296-A-25$ & ok & ok & ok & $\begin{array}{l}\text { under } \\
\text { probe }\end{array}$ & $2 \%$ & $21 \%$ \\
\hline $296-A-27$ & ok & ok & $\overline{\text { ok }}$ & $\begin{array}{l}\text { under } \\
\text { probe }\end{array}$ & $1 \%$ & $24 \%$ \\
\hline $296-A-29$ & ok & ok & ok & $\begin{array}{l}\text { under } \\
\text { probe }\end{array}$ & $1 \%$ & ok \\
\hline $296-\mathrm{A}-40$ & $\overline{\text { ok }}$ & $\mathrm{no}^{1}$ & ok & $\overline{\text { ok }}$ & $\overline{\text { NA }}$ & \\
\hline $296-B-28$ & $\overline{\text { ok }}$ & $\mathrm{no}^{1}$ & ok & $\begin{array}{l}\text { under } \\
\text { probe }\end{array}$ & $2 \%$ & $24 \%$ \\
\hline $296-C-05$ & ok & ok & one & $\overline{\text { ok }}$ & $\overline{\mathrm{NA}}$ & $91 \%$ \\
\hline $296-P-16$ & ok & ok & one & $\overline{\text { ok }}$ & $\overline{\mathrm{NA}}$ & $23 \%$ \\
\hline $296-P-23$ & ok & ok & ok & $\begin{array}{l}\text { under } \\
\text { probe }\end{array}$ & $1 \%$ & $24 \%$ \\
\hline $296-\mathrm{P}-28$ & ok & no ${ }^{1}$ & one & $\begin{array}{l}\text { under } \\
\text { probe }\end{array}$ & $\overline{1 \%}$ & $29 \%$ \\
\hline $296-S-15$ & ok & ok & one & ducts & $\overline{\mathrm{NA}}$ & $55 \%$ \\
\hline $296-S-22$ & ok & $\overline{\text { no }}$ & one & $\begin{array}{l}\text { under } \\
\text { probe }\end{array}$ & $4 \%$ & ok \\
\hline $296-T-18$ & ok & $\overline{n^{1}}$ & ok & $\begin{array}{l}\text { under } \\
\text { probe }\end{array}$ & $2 \%$ & $39 \%$ \\
\hline
\end{tabular}

${ }^{1}$ No - indicates that the stack flow measurement procedure does not call for the same number of flow measurement traverse points as is called for by 40 CFR 60, Appendix A, Method 1A. 
WHC-EP-0479-1

This next table lists deficiencies with the sample probe and current sample analysis.

Table 15-4. Sample Probe and Sample Analysis.

\begin{tabular}{|c|c|c|c|c|c|}
\hline \multirow[b]{2}{*}{ Stack } & \multicolumn{4}{|c|}{ Sample Probe } & \multirow{2}{*}{ 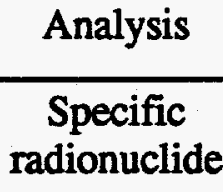 } \\
\hline & Location & $\begin{array}{c}\text { Number of } \\
\text { nozzles }\end{array}$ & $\begin{array}{l}\text { Nozzle } \\
\text { length }\end{array}$ & $\begin{array}{l}\text { Nozzle bend } \\
\text { radius }\end{array}$ & \\
\hline 296-A-17 & ok & ok & ok & ok & ok \\
\hline $296-P-26$ & ok & ok & ok & ok & ok \\
\hline $296-A-25$ & ok & ok & ok & ok & CY 95 \\
\hline 296-A-27 & ok & ok & no & no & ok \\
\hline 296-A-29 & ok & ok & no & no & ok \\
\hline $296-A-40$ & ok & ok & ok & ok & CY 95 \\
\hline 296-B-28 & ok & ok & ok & ok & CY 95 \\
\hline 296-C-05 & ok & 1 not 3 & ok & ok & CY 95 \\
\hline 296-P-16 & ok & ok & ok & ok & CY 95 \\
\hline 296-P-23 & ok & ok & ok & ok & ok \\
\hline 296-P-28 & ok & ok & ok & ok & CY 95 \\
\hline $296-S-15$ & $\begin{array}{l}\text { stack too } \\
\text { short }\end{array}$ & ok & no & ok & CY 95 \\
\hline $296-S-22$ & ok & ok & no & no & CY 95 \\
\hline $296-T-18$ & ok & ok & ok & ok & CY 95 \\
\hline
\end{tabular}




\subsection{FUTURE USE/EXISTING UPGRADES PLANS}

This section discusses future use and currently planned upgrades.

\subsubsection{Stacks Being Replaced by W-030 Project}

The 296-A-17 and 296-P-26, stacks for the AY/AZ Tank Farm Facilities are being replaced via the W-030 Project. This replacement is driven by Tri Party Agreement Milestones. Important milestone dates are:

- Milestone No. M-43-01 - Complete Ventilation Upgrades by 12/31/1996

- Milestone No. M-43-01A - Start Construction by 10/31/1994

- Milestone No. M-43-01B - Complete Construction by 10/31/1996

- Milestone No. M-43-01C - Begin Operation by 12/31/1996.

\subsubsection{Stacks Planned for Replacement by W-420 Project}

The following stacks are planned for replacement by project $\mathrm{W}-420$ :

\begin{tabular}{|c|c|}
\hline & \\
\hline & $241-\mathrm{AW} \mathrm{T}$ \\
\hline 9 & Farm Exhauster \\
\hline 0 & 244-BX Double Contained Receiver Ta \\
\hline & $244-C$ \\
\hline & 241 \\
\hline & \\
\hline & 241-SY Tank Farm Exhauster \\
\hline & 241-SX Tank Farm Exhauster \\
\hline & ontained Rece \\
\hline & nod \\
\hline
\end{tabular}

Important milestone dates are:

- Provide Design Requirement Document to EPA by 10/31/95.

- Design Requirement Review by 4/30/96.

- Begin Construction by $6 / 30 / 99$.

- Finish Construction by 12/31/05.

- Provide Documentation to EPA by $4 / 30 / 06$. 


\subsection{CONCLUSION}

All identified major Tank Farms airborne effluent sources are in compliance with the Federal

Facility Compliance Agreement for Radionuclide NESHAP. 
WHC-EP-0479-1

This page intentionally left blank. 


\subsection{REFERENCES}

40 CFR 52, 1989, "Approval and Promulgation of Implementation Plans, " Code of Federal Regulations, as amended, U.S. Environmental Protection Agency, Washington, D.C.

40 CFR 60, 1990, "Quality Assurance Methods," Code of Federal Regulations, as amended, U.S. Environmental Protection Agency, Washington, D.C.

40 CFR 61, 1989, "National Emission Standards for Hazardous Air Pollutants (NESHAP)," Code of Federal Regulations, as amended, U.S. Environmental Protection Agency, Washington, D.C.

40 CFR 70, 1992, "State Operating Permit Program," Code of Federal Regulations, as amended.

40 CFR 122, 1983, "EPA-Administered Permit Programs: The National Pollutant Discharge Elimination System," Code of Federal Regulations, as amended.

40 CFR 141, 1989, "National Primary Drinking Water Regulations," Code of Federal Regulations, as amended, U.S. Environmental Protection Agency, Washington, D.C.

40 CFR 191, 1985, "Disposal of Spent Nuclear Fuel, High-Level and Transuranic Radioactive Wastes," Code of Federal Regulations, as amended.

40 CFR 261, 1989, "Identification and Listing of Hazardous Waste," Code of Federal Regulations, as amended.

40 CFR 262, 1988, "Standards Applicable to Generators of Hazardous Waste," Code of Federal Regulations, as amended.

40 CFR 264, 1988, "Standards for Owners and Operators of Hazardous Waste Treatment, Storage and Disposal Facilities," Code of Federal Regulations, as amended.

40 CFR 265, 1988, "Groundwater Monitoring," Code of Federal Regulations, as amended.

40 CFR 302.4, 1990, "Designation, Reportable Quantities, and Notification Requirements for Hazardous Substances Under CERCLA," Code of Federal Regulations, as amended, U.S. Environmental Protection Agency, Washington, D.C.

40 CFR 355, 1987, "Superfund Amendments and Reauthorization Act of 1986 (SARA): Emergency Planning and Notification," Code of Federal Regulations, as amended.

40 CFR 401-471, 1994, "Effluent Guidelines and Standards," Code of Federal Regulations, as amended. 
40 CFR 403-471, 1990, "Effluent Guidelines Standards," Code of Federal Regulations, as amended.

ANSI, 1966, Practice for Occupational Radiation Exposure Records System, ANSI N13.6, American National Standards Institute, New York, New York.

ANSI, 1969, American National Standard Guide to Sampling Airborne Radioactive Materials in Nuclear Facilities, American National Standards Institute, ANSI N13.1 1969, New York, New York.

ANSI, 1974, Specification and Performance of Onsite Instrumentation for Continuously Monitoring Radioactivity in Effluents, American National Standards Institute, ANSI N42.18-1974, New York, New York.

Atomic Energy Act of 1954, 42 USC 2011, et seq.

Benton-Franklin/Walla Walla Counties Air Pollution Control Authority, 1993, Regulation 1 of the Benton-Franklin/Walla Walla Counties Air Pollution Control Authority, Kennewick, Washington.

Butcher, K., 1991, Versapor 3000 DOP Efficiency, (Letter to C. Kirk, Westinghouse Hanford Company, October 31), Gelman Sciences, Ann Arbor, Michigan.

Clean Air Act of 1977, as amended, 33 USC 1251, et seq.

Clean Water Act of 1977, as amended, Public Law 95-217, 92 Stat 1566, 33 USC 1251 et seq.

Comprehensive Environmental Response, Compensation, and Liability Act of 1980, (CERCLA), 42 USC 9601, et seq.

Crummel, G. M., A. K. Dasgupta, and L. P. Diediker, 1992, 242-A Evaporator Comparison with 40 CFR 61, Subpart H, and Other Referenced Guidelines for Stack C-22, WHC-EP-0542, Westinghouse Hanford Company, Richland, Washington.

Crummel, G. M., and R. D. Gustavson, 1995, Facility Effluent Monitoring Plan for 242-A Evaporator Facility, WHC-EP-0466-2, Westinghouse Hanford Company, Richland, Washington.

Diediker, L. P., 1994, Analytical Requirements for Effluent Sampling CY 1995, (internal memorandum 88420-94-130 to E. J. Kosiancic, November 7), Westinghouse Hanford Company, Richland, Washington. 
Dodd, D. A., 1991, Minimum Detectable Concentrations - 222-S Laboratory, (internal memo 28200-91-018 to D. G. Carpenter, March 27), Westinghouse Hanford Company, Richland, Washington.

DOE, 1980, Guide to Reducing Radiation Exposure to As Low As Reasonably Achievable, DOE/EV/1830-T5, U.S. Department of Energy, Washington, D.C.

DOE, 1988a, Radiation Protection for Occupational Workers, DOE Order 5480.11, U.S. Department of Energy, Washington, D.C.

DOE, 1988b, Radioactive Waste Management, DOE Order 5820.2A, U.S. Department of Energy, Washington, D.C.

DOE, 1989, General Design Criteria, DOE Order 6430.1A, U.S. Department of Energy, Washington, D.C., December 25, 1987.

DOE, 1990a, General Environmental Protection Program, DOE Order 5400.1, U.S. Department of Energy, Washington, D.C.

DOE, 1990b, Environmental Protection, Safety, and Health Protection Information Reporting System, DOE Order 5484.1, U.S. Department of Energy, Washington, D.C.

DOE, 1990c, Radiation Protection of the Public and the Environment, DOE Order 5400.5, U.S. Department of Energy, Washington, D.C.

DOE, 1991a, Quality Assurance, DOE Order 5700.6C, U.S. Department of Energy, Washington, D.C.

DOE, 1991b, Environmental Regulatory Guide for Radiological Effluent Monitoring and Environmental Surveillance, DOE/EH-0173T, U.S. Department of Energy, Washington, D.C.

DOE, 1993a, Environmental Protection, Safety and Health Protection Standards, DOE Order 5480.4, U.S. Department of Energy, Washington, D.C.

DOE, 1993b, Occurrence Reporting and Processing of Operations Information, DOE Order 5000.3B, U.S. Department of Energy, Washington, D.C.

DOE/RL, 1990, Double-Shell Tank System Dangerous Waste Permit Application, DOE/RL-90-39 (Internal Review Draft), Rev. 0, Vol. 1, U.S. Department of Energy, Richland Operations Office, Richland, Washington.

DOE/RL, 1991, Calendar Year 1990 Air Emissions Report for the Hanford Site, DOE/RL-91-10, U.S. Department of Energy, Richland Operations Office, Richland, Washington. 
DOE/RL, 1992, Radionuclide Air Emission Report for the Hanford Site CY 1991, DOE/RL-92-30, U.S. Department of Energy, Richland Operations Office, Richland, Washington.

DOE/RL, 1993, Radionuclide Air Emission Report for the Hanford Site CY 1992, DOE/RL-93-36, U.S. Department of Energy, Richland Operations Office, Richland, Washington.

DOE/RL, 1994, Radionuclide Air Emission Report for the Hanford Site CY 1993, DOE/RL-94-51, U.S. Department of Energy, Richland Operations Office, Richland, Washington.

Ecology, EPA, and DOE, 1994, Hanford Federal Facility Agreement and Consent Order, Washington State Department of Ecology, U.S. Environmental Protection Agency, and U.S. Department of Energy, Olympia, Washington.

Hanlon, B. M., 1991, Tank Farm Surveillance and Waste Status Summary Report for November 1990, WHC-EP-0182-32, Westinghouse Hanford Company, Richland, Washington.

Hanson, G. L., R. R. Jackson, and J. R. LaRiviere, 1980, Safety Analysis Report - Salt Well Waste Receiver Facilities, SD-WM-SAR-032, Rev. 0, Rockwell Hanford Operations, Richland, Washington.

ICRP, 1979, International Commission on Radiological Protection (ICRP), 1979, Limits for Intakes of Radionuclides by Workers, ICRP Publication 30, Pergamon Press, Oxford.

Joncus, S. J., 1990, Operating Specifications for Saltwell Receiver Vessels, OSD-T-151-00011, Rev. B-1, Westinghouse Hanford Company, Richland, Washington.

MOU, 1989, Memorandum of Understanding, Pacific Northwest Laboratory and Westinghouse Hanford Company, Richland, Washington.

Poeten, R. W., 1994, Modifications Made to the 242-A Evaporator Vessel Vent Stack Monitoring System, (letter to J. D. Bauer, DOE-RL, January 18), U.S. Environmental Protection Agency, Seattle, Washington.

Resource Conservation and Recovery Act of 1976 (RCRA), 42 USC 6901, et seq.

RHO, 1980a, 200 Area Stake Sampler/Monitor Systems Upgrade: Generic Systems Applications, RHO-CD-1092, Rockwell Hanford Organization, Richland, Washington.

RHO, 1980b, Installation Criteria for the Generic Stack Monitoring System, RHO-MA-241, Rockwell Hanford Operations, Richland, Washington. 
Rhoads, K., 1991, Unit Dose Calculations for WHC Facility Effluent Monitoring Plans, WHC-EP-0498, Pacific Northwest Laboratory, Richland, Washington.

Safe Drinking Water Act of 1974, 42 USC 3007, et seq.

WAC 173-200, 1990, "Water Quality Standards for Groundwater of the State of Washington, Washington Administrative Code, as amended.

WAC 173-216, 1991, "State Waste Discharge Permit Program," Washington Administrative Code, as amended, Washington State Department of Ecology, Olympia, Washington.

WAC 173-220, 1990, "National Pollutant Discharge Elimination System Permit Program," Washington Administrative Code, as amended, Washington State Department of Ecology, Olympia, Washington.

WAC 173-240, 1990, "Submission of Plans and Reports for Construction of Waste Water Facilities," Washington Administraive Code, as amended.

WAC 173-303, 1989, "Dangerous Waste Regulations," Washington Administrative Code, as amended April 4, 1991, Washington State Department of Ecology, Olympia, Washington.

WAC 173-400, 1991, "General Regulations for Air Pollution Sources," Washington Administrative Code, as amended, Chapter 173-400, Washington Stage Department of Ecology, Olympia, Washington.

WAC 173-401, 1994, "Air Operating Permit Program," Washington Administrative Code, as amended.

WAC 173-460, 1991, "Control for New Sources of Toxic Air Pollutants," Washington Administrative Code, as amended.

WAC 173-480, 1990, "Ambient Air Quality Standards and Emission Limits for Radionuclides," Washington Administrative Code, as amended, Washington State Department of Ecology, Olympia, Washington.

WAC 246-247, 1994, "Radiation Protection - Air Emissions," Washington Administrative Code, as amended, Washington State Department of Health, Olympia, Washington.

Washington Clean Air Act of 1991, Revised Code of Washington, Title 20, Public Health and Safety Chapter 94, as amended.

WHC, 1981, Design Review \#0179 - Test Procedure for Generic Design Exhaust Stack Sampler/Monitor Application to 200 Area Exhaust Stacks, ATP-G999-00010, Rev. 0A, Westinghouse Hanford Company, Richland, Washington. 
WHC, 1985, Waste Transfer and Routing Facilities, Facility Description Manual, FDT-T-020-00002, Westinghouse Hanford Company, Richland, Washington.

WHC, 1986a, Double-Shell Tank Farm Facility (241-AN, AW, AP, and SY) Safety Analysis Report, WHC-SD-WM-SAR-016, Rev. 1, Westinghouse Hanford Company, Richland, Washington.

WHC, 1986b, Single-Shell Tank Isolation Safety Analysis Report, WHC-SD-WM-SAR-006, Rev. 2, Westinghouse Hanford Company, Richland, Washington.

WHC, 1988, Westinghouse Hanford Company Effluent Discharges and Solid Waste Management Report for 1987: 200/600/1100 Areas, WHC-EP-0141, Westinghouse Hanford Company, Richland, Wasington.

WHC, 1989a, Westinghouse Hanford Company Effluent Discharges and Solid Waste Management Report for 1988: 200/600 Areas, WHC-EP-0141-1, Westinghouse Hanford Company, Richland, Washington.

WHC, 1989b, Aging Waste Facility Safety Analysis Report, WHC-SD-HS-SAR-010, Rev. 2, Westinghouse Hanford Company, Richland, Washington.

WHC, 1990, Westinghouse Hanford Company Effluent Discharges and Solid Waste Management Report: 200/600 Areas, Calendar Year 1989, WHC-EP-0141-2, Westinghouse Hanford Company, Richland, Washington.

WHC, 1991a, Facility Effluent Monitoring Plan Determinations for 200 Area Facilities, WHC-EP-0440, Vols. 1 and 2, Westinghouse Hanford Company, Richland, Washington.

WHC, 1991b, Management Plan for Facility Effluent Monitoring Plan Activities, WHC-EP-0491, Westinghouse Hanford Company, Richland, Washington.

WHC, 1992a, 244-AR Vault Cooling Water Sampling and Analysis Plan, WHC-SD-WM-EV-076, Rev. 2, Westinghouse Hanford Company, Richland, Washington.

WHC, 1992b, 241-A Tank Farm Cooling Water Sampling and Analysis Plan, WHC-SD-WM-EV-077, Rev. 2, Westinghouse Hanford Company, Richland, Washington.

WHC, 1992c, A Guide for Preparing Hanford Facility Effluent Monitoring Plans, WHC-EP-0438-1, Westinghouse Hanford Company, Richland, Washington.

WHC, 1992d, Environmental Releases for Calendar Year 1991, WHC-EP-0527-1, Westinghouse Hanford Company, Richland, Washington. 
WHC, 1992e, Automated Bar Coding of Air Samples at Hanford (ABCASH), WHC-SA-1554-FP, Westinghouse Hanford Company, Richland, Washington.

WHC, 1993a, Environmental Releases for Calendar Year 1992, WHC-EP-0527-2, Westinghouse Hanford Company, Richland, Washington.

WHC, 1993b, Quality Assurance Program Plan for the Chemical Analysis of Highly Radioactive Mixed Waste Samples in Support of Environmental Activities on the Hanford Site, WHC-SD-CP-QAPP-002, Rev. 0A, Westinghouse Hanford Company, Richland, Washington.

WHC, 1993c, Routine Operational Environmental Monitoring Schedule CY 1994, WHC-SP-0098-5, Westinghouse Hanford Company, Richland, Washington.

WHC, 1994a, Health Physics Procedures Manual, WHC-IP-0718, Westinghouse Hanford Company, Richland, Washington.

WHC, 1994b, Quality Assurance Project Plan for Facility Effluent Monitoring Plan Activities, WHC-EP-0446-2, Westinghouse Hanford Company, Richland, Washington.

WHC, 1994c, Environmental Releases for Calendar Year 1993, WHC-EP-0527-3, Westinghouse Hanford Company, Richland, Washington.

WHC, 1994d, Quality Assurance Project Plan for Radioactive Airborne Emissions Data Compilation and Reporting, WHC-EP-0528-1, Westinghouse Hanford Company, Richland, Washington.

WHC, 1994e, Tank Farm Stack Sampling Configuration and Efficiency Study, WHC-SD-WM-ES-291-1, Westinghouse Hanford Company, Richland, Washington.

WHC, 1994f, Functional Requirements Document for Measuring Emissions of Airborne Radioactive Materials, WHC-SD-EN-TI-288, Westinghouse Hanford Company, Richland, Washington.

WHC, 1994g, Tank Exhaust Comparison with 40 CFR 61.93, Subpart H, and Other Referenced Guidelines for Tank Farms NESHAP Designated Stacks, WHC-EP-0784, Westinghouse Hanford Company, Richland, Washington.

WHC, 1994h, Quality Assurance Program Plan for Laboratory Analyses and Process Testing, WHC-SD-CP-QAPP-003, Rev. 1, Westinghouse Hanford Company, Richland, Washington.

WHC, 1994i, Operating Specifications for Single-Shell Waste Storage Tanks, OSD-T-151-00013, Rev. D-4, Westinghouse Hanford Company, Richland, Washington. 
WHC, 1994j, Operating Specifications for the 241-A-702 Vessel Ventilation System, OSD-T-151-00016, Rev. C-2, Westinghouse Hanford Company, Richland, Washington.

WHC, 1994k, Environmental Releases for CY 1993, WHC-EP-0527-3, Westinghouse Hanford Company, Richland, Washington.

WHC, 1994L, WHC Operational Environmental Monitoring Annual Report, CY 1993, WHC-EP-0573-2, Westinghouse Hanford Company, Richland, Washington.

WHC, 1994m, Determination of the NESHAP Status of Tank Farm Stacks Based on Calculations Using 40 CFR 61 - Appendix D Factors, WHC-SD-WM-EMP-031, Rev. 0A, Westinghouse Hanford Company, Richland, Washington.

WHC, 1995a, Air Flow Test for Tank Farm Stacks and Ducts, 6-TF-155, Westinghouse Hanford Company, Richland, Washington.

WHC, 1995b, Operating Specifications for 241 AN, AP, AW, AY, AZ and SY Tank Farms, OSD-T-151-00007, Rev. H-10, Westinghouse Hanford Company, Richland, Washington.

WHC, 1995c, Operating Specifications for Miscellaneous Facilities, OSD-T-151-00015, Rev. B-6, Westinghouse Hanford Company, Richland, Washington.

WHC-CM-1, Company Policies and Charters, Westinghouse Hanford Company, Richland, Washington.

WHC-CM-1-3, Management Requirements and Procedures, Westinghouse Hanford Company, Richland, Washington.

WHC-CM-4-1, Emergency Plan, Westinghouse Hanford Company, Richland, Washington.

WHC-CM-4-2, Quality Assurance Manual, Westinghouse Hanford Company, Richland, Washington.

WHC-CM-5-9, PUREX/UO ${ }_{3}$ Plant Administration, Westinghouse Hanford Company, Richland, Washington.

WHC-CM-7-4, Operational Environmental Monitoring, Westinghouse Hanford Company, Richland, Washington.

WHC-CM-7-5, Environmental Compliance Manual, Westinghouse Hanford Company, Richland, Washington. 


\section{DISTRIBUTION}

\section{Number of Copies}

ONSITE

U.S. Department of Energy, Richland Operations Office

J. D. Bauer

R. G. Holt

A5-15

E. B. Dagan

A5-15

S. D. Stites

A5-19

Public Reading Room

A5-19

H2-53

8

Pacific Northwest Laboratory

W. J. Bjorklund

P7-68

T. D. Chikalla

P7-75

G. R. Hoenes

P7-78

R. E. Jaquish

K1-30

G. A. Simiele

P7-79

R. K. Woodruff

K6-13

Technical Files

K1-11

Hanford Technical Library

P8-55

50

Westinghouse Hanford Company

D. Alison

R1-52

D. D. Bachand (5)

R1-52

L. E. Borneman

R2-06

F. E. Boyd

R. L. Brown

S6-12

S. L. Bump

R3-12

C. L. Caldwell

T4-01

D. J. Carrell

S4-39

H6-22

G. J. Coleman

T4-07

G. M. Crummel

R1-51

L. P. Diediker

T1-30

J. J. Dorian

H6-30

J. A. Eacker

R1-51

W. T. Dixon

H6-21

R. V. Filkowski

T4-07

T. P. Frazier (10)

T1-30 


\section{DISTRIBUTION (continued)}

Number of Copies

ONSITE

Westinghouse Hanford Company (continued)

$\begin{array}{ll}\text { D. W. Fritz } & \text { H6-22 } \\ \text { B. P. Geckler } & \text { T1-30 } \\ \text { C. J. Geier } & \text { R2-36 } \\ \text { J. L. Geiger } & \text { R3-01 } \\ \text { E. M. Greager } & \text { H6-30 } \\ \text { R. D. Gustavson } & \text { R1-51 } \\ \text { D. G. Hamrick } & \text { S6-15 } \\ \text { R. E. Johnson } & \text { T1-30 } \\ \text { T. D. Kaiser } & \text { T4-07 } \\ \text { R. E. Larson } & \text { T4-07 } \\ \text { P. J. Martell } & \text { H6-30 } \\ \text { J. E. Pieper } & \text { R3-12 } \\ \text { S. R. Pierce } & \text { S5-05 } \\ \text { D. W. Ranade } & \text { B2-16 } \\ \text { D. P. Reber } & \text { T4-08 } \\ \text { L. W. Vance } & \text { H4-16 } \\ \text { D. D. Volkman } & \text { H4-16 } \\ \text { J. H. Wicks } & \text { S5-07 } \\ \text { Central Files } & \text { L8-04 } \\ \text { OSTI (2) } & \text { L8-07 }\end{array}$

